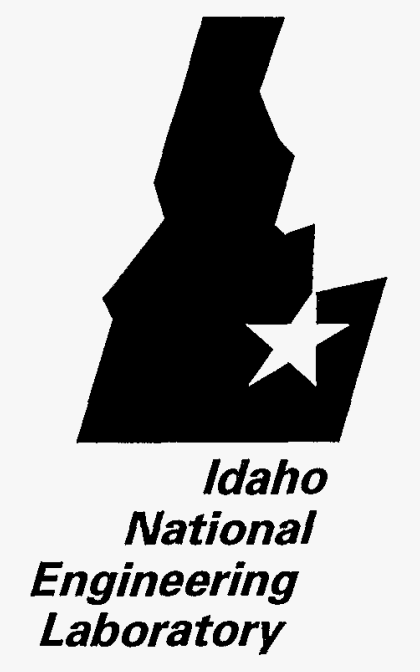

INEL-96/0146

September 5, 1996

\title{
Decontamination and Decarburization of Stainless and Carbon Steel by Melt Refining
}

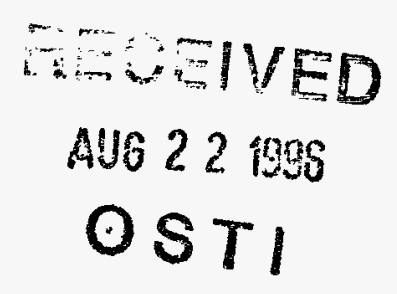

Authors:

Prof. S. A. Worcester

Prof. L. G. Twidwell, Mr. D. Webber

Mr. D. J. Paolini

Mr. T. A. Weldon

Editor:

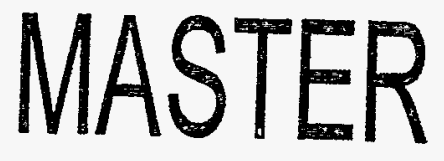

Mr. R. E. Mizia

DISTRABUTION OF THS DOCUMENT IS UALMITED

三人lockheed

$R \beta$ 
INEL-96/0146

\section{Decontamination and Decarburization of Stainless and Carbon Steel by Melt Refining}

Prof. S. A. Worcester, et al.

R. E. Mizia, Editor (LITCO)

Published September 5, 1996

Montana Tech of The University of Montana Butte, Montana 59701-8997

Prepared for Lockheed Idaho Technologies Company

Under Subcontract No. C85-110767

and for the

U.S. Department of Energy

Assistant Secretary for Environmental Management

Under DOE Idaho Operations Office

Contract DE-AC07-94ID13223 


\section{ACKNOWLEDGMENTS}

The authors wish to acknowledge the financial support of the Department of Energy, under Special Master Research Contract C85-110767, which made this work possible. The foundry and analytical support given the program by AFFCO, Anaconda, MT went far beyond the service expected from a pure tolling arrangement. Schlosser Forge Company, Cucamonga, CA donated the forging services on the steel surrogate ingots, and The Oregon Graduate Institute for Science and Technology sectioned the initial stainless steel surrogate ingots. Their assistance is greatly appreciated. Neutron activation analysis for surrogates was provided by The Radiation Laboratory at Oregon State University, Corvallis, OR, and X-Ray fluorescence analysis of slags by Ashe Analytics, Butte, MT. The timely induction coupled plasma mass spectrometry and carbon analysis provided by the Teledyne Wah Chang Albany Analytical Laboratory, Albany, OR contributed greatly to the success of the program. Special thanks go to Rosalie Murphy, Metallurgical Department Secretary, who makes documents look presentable, maintains some level of department sanity, and provides that necessary smile when times are tough. To all of these participants and others who helped in the program, the authors express their sincere thanks; a special thanks to the DOE project manager, Mr. Ron Mizia, for his invaluable guidance. 


\section{DISCLAIMER}

Portions of this document may be illegible in electronic image products. Images are produced from the best available original document. 


\section{DISCLAIMER}

This report was prepared as an account of work sponsored by an agency of the United States Government. Neither the United States Government nor any agency thereof, nor any of their employees, makes any warranty, express or implied, or assumes any legal liability or responsibility for the accuracy, completeness, or usefulness of any information, apparatus, product, or process disclosed, or represents that its use would not infringe privately owned rights. Reference herein to any specific commercial product, process, or service by trade name, trademark, manufac. turer, or otherwise does not necessarily constitute or imply its endorsement, recommendation, or favoring by the United States Government or any agency thereof. The views and opinions of authors expressed herein do not necessarily state or reflect those of the United States Government or any agency thereof. 


\title{
DECONTAMINATION AND DECARBURIZATION OF STAINLESS AND CARBON STEEL BY MELT REFINING
}

\author{
EXECUTIVE SUMMARY
}

\section{THE PROBLEM}

With many nuclear reactors and facilities being decommissioned in the next ten to twenty years the concern for handling and storing Radioactive Scrap Metal (RSM) is growing. Upon direction of the DOE Office of Environmental Restoration and Waste Management, Lockheed Idaho Technology Company (LITCO) is developing technologies for the conditioning of spent fuels and high-level wastes for interim storage and repository acceptance, including the recycling of Radioactive Scrap Metals (RSM) for beneficial re-use within the DOE complex.

The current RSM inventory for the Idaho National Engineering Laboratory (INEL) is estimated at 1.0 million kilograms which include 175,900 kilograms as iron or carbon steel, 294,300 kilograms as stainless steel. RSM steel and stainless steel projections for Decontamination and Decommissioning (D\&D) for the INEL are estimated to be 23,759,600 kilograms and 37,613,100 kilograms, respectively. Nichols has estimated that the annual generation of RSM for the entire DOE complex will be approximately $109,000,000 \mathrm{~kg}$ (120,000 tons) beginning in 1999-2000.

\section{MONTANA TECH PROGRAM}

In February 1993, WINCO (previous INEL Metal Recycle Program manager) contracted with Montana Tech of the University of Montana to develop and demonstrate technologies for the decontamination of stainless steel RSM. This program was designed to complement and support other INEL Recycle Program efforts with the Oregon Graduate Institute (OGI), Sandia National Laboratories, Newport News Shipbuilding, Savanah River Site, Colorado School of Mines, and the Northwest Consortium (OGI, Teledyne Wah Chang Albany, Northwest Pipe and Casing, Sacramento Municipal Utility District, and Portland General Electric).

The general objectives of the Montana Tech research program included conducting a literature survey, performing laboratory scale melt refining experiments to optimize decontaminating slag compositions, performing an analysis of preferred melting techniques, coordinating pilot scale and commercial scale demonstrations, and producing sufficient quantities of surrogate-containing material for all of the laboratory, pilot and commercial scale test programs. Later on, the program was expanded to include decontamination of carbon steel RSM. Specific objectives of the Montana Tech research program included the following components:

- Review the literature as it relates to decontamination of radioactive elements from stainless steel and carbon steel. Prepare an annotated summary of the published literature. (Two reports were issued during the contract period.)

- Design appropriate slag formulations for use in a laboratory experimental study. 
- Investigate the usefulness of calculational programs to predict the thermodynamic distribution of species between gaseous and condensed phases as a function of a number of system variables, e.g., temperature, impurity content, selected additive flux constituents, and gas composition.

- $\quad$ Conduct laboratory experimental studies and thermodynamic calculations to optimize the selection of appropriate slag formulations.

- $\quad$ Conduct laboratory experimental studies and thermodynamic calculations to optimize the selection of appropriate refractories for the selected slag formulation(s).

- $\quad$ Apply the results of the laboratory studies to pilot scale studies and commercial scale studies to demonstrate effective decontamination technology(s) for slag/melt refining. This phase included melting of pilot-scale quantities (several hundred pounds) and commercial scale quantities (several thousand pounds) of surrogate-containing stainless and carbon steel (surrogate preparation techniques insured introduction of measurable quantities of non-oxidized surrogates into all master alloys) for demonstration programs.

Each research program (steel and stainless steel) has been completed. Results of these programs are presented in this report, and other publications issued during this program are listed in Section 1.3

\section{PROGRAM RESULTS}

Radionuclides with oxide free energies of formation (based on one mole of oxygen gas) that are significantly lower than the free energies of formation for the steel constituent oxides potentially can be removed from the RSM by Melt Refining/Slagging. This melt refining process has been proven effective in agreement with the results found in the literature and based on the results of the Montana Tech research program. Radionuclides with high vapor pressure (strontium and cesium) were also removed.

Surrogates used in the present study included an isotopic mixture of cerium, strontium, neodymium, lanthanum, and cesium. Cesium and strontium represent radioactive isotopes of their own elements; while neodymium, lanthanum and cerium were chosen to simulate the metal/slag distribution characteristics of uranium, plutonium, radioactive isotopes of the lanthanide elements, and the other actinide elements.

Melting fluxes were chosen from the literature and thermochemical calculations performed using the CSIRO/MONASH Thermochemistry Software. The results for both the stainless and carbon steel research programs indicate that induction melting in an open atmosphere will (with and without the presence of flux additions) sufficiently lower the surrogate concentration levels of the master 
surrogate ingot to below $1.0 \mathrm{ppm}$ after five minutes at a melting temperature of $1600^{\circ} \mathrm{C}$. This result has been demonstrated on the scale of a few pounds up to approximately one ton.

After demonstration of removal of surrogates, it became apparent that it was desirable to produce stainless steel that met low carbon requirements to increase product utility and value. For many applications, i.e. long term waste and fuel containers, SS304 with a carbon content greater than 0.03 $\%$ is unacceptable for welded components. Therefore, a series of pilot scale experiments (200-250 pounds) utilizing vacuum induction melting (VIM) have been performed to demonstrate the effective removal of surrogate elements and to investigate the lowering of carbon to specification levels. The results show that effective decontamination of the surrogate elements and the lowering of carbon content (from approximately $1000 \mathrm{ppm}$ to $300 \mathrm{ppm}$ ) can be achieved in one melting step in a vacuum environment using either ferric oxide (magnetite) additions or carbon dioxide gas surface sparging. Additional advantages of VIM demonstrated during the program were: minimization of slag formation to minimize the quantities of radioactive materials which must subsequently be disposed of, and positive control of fume and offgas during the melting operation. 
DECONTAMINATION AND DECARBURIZATION OF STAINLESS STEEL AND

CARBON STEEL BY MELT REFINING

TABLE OF CONTENTS

TITLE PAGE

ACKNOWLEDGMENTS

EXECUTIVE SUMMARY

TABLE OF CONTENTS

LIST OF TABLES

LIST OF FIGURES

1.1. Background $\ldots \ldots \ldots \ldots \ldots \ldots \ldots \ldots \ldots \ldots \ldots \ldots \ldots \ldots \ldots \ldots \ldots \ldots$

1.2. Radionuclides in Nuclear Power Reactors $\ldots \ldots \ldots \ldots \ldots \ldots \ldots \ldots \ldots \ldots \ldots \ldots \ldots$

1.3. Publications Resulting from This Study $\ldots \ldots \ldots \ldots \ldots \ldots \ldots \ldots \ldots \ldots \ldots \ldots$

1.4. Publications Resulting from Companion Studies $\ldots \ldots \ldots \ldots \ldots \ldots \ldots \ldots$

SECTION TWO: RESEARCH PROGRAM $\ldots \ldots \ldots \ldots \ldots \ldots \ldots \ldots$

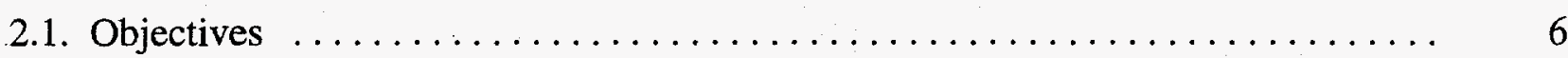

2.2. Literature Survey/Annotation for Stainless and Carbon Steel . . . . . . . . . 7

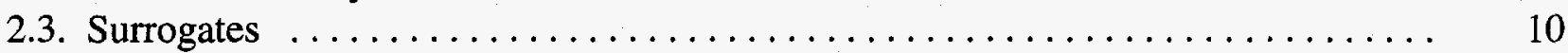

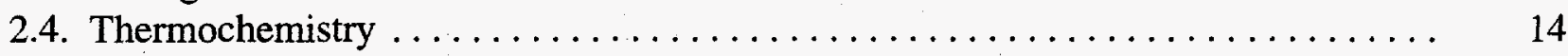

2.5. Calculational Programs $\ldots \ldots \ldots \ldots \ldots \ldots \ldots \ldots \ldots \ldots \ldots \ldots \ldots \ldots \ldots \ldots$

SECTION THREE: RESEARCH PROGRAM: LABORATORY SCALE

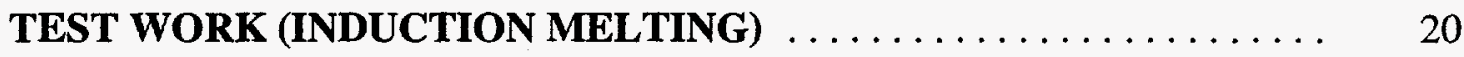

3.1. Goals of the Laboratory Test Work $\ldots \ldots \ldots \ldots \ldots \ldots \ldots \ldots \ldots \ldots \ldots \ldots$

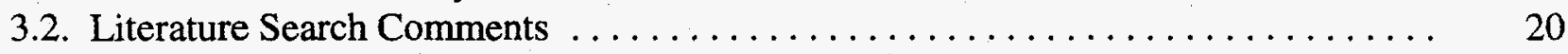

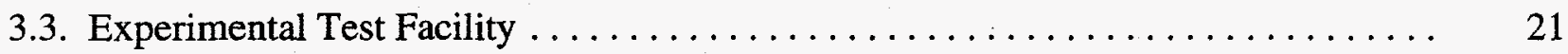

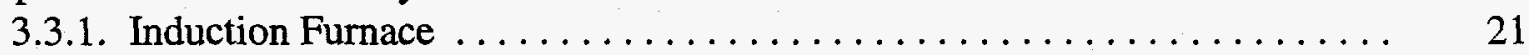

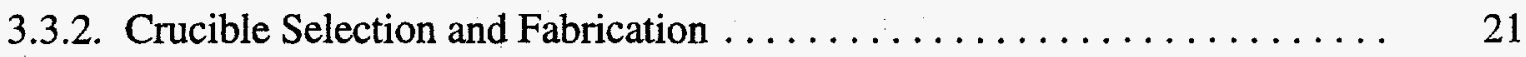

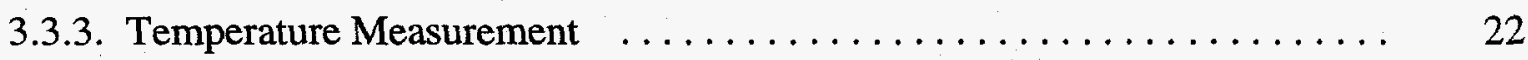

3.4. Master Surrogate Ingot and Flux Preparation $\ldots \ldots \ldots \ldots \ldots \ldots \ldots \ldots \ldots \ldots \ldots$

3.4.1. Master Ingot Preparation . . . . . . . . . . . . . . . . . . 23

3.4.1.1. Stainless Steel Master Ingot Preparation $\ldots \ldots \ldots \ldots \ldots \ldots \ldots \ldots \ldots$

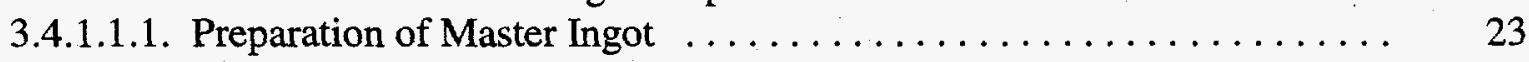

3.4.1.1.2. Sectioning, Sampling and Analysis of the Master Ingot . . . . . . . . 25

3.4.1.1.3. Master Ingot Composition and Discussion . . . . . . . . . . . 27 


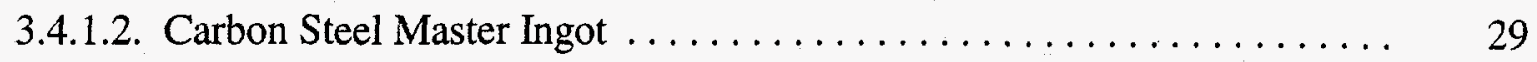

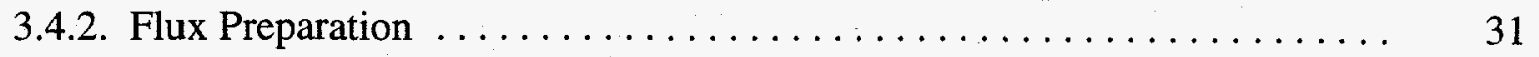

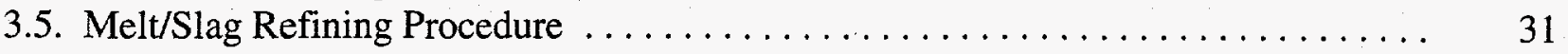

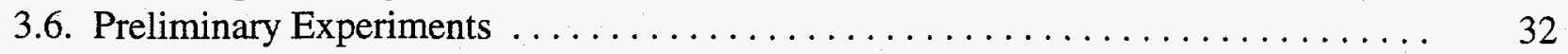

3.6.1. Preliminary Experiments: Metal Phase $\ldots \ldots \ldots \ldots \ldots \ldots \ldots \ldots \ldots .33$

3.6.2. Preliminary Experiments: Slags $\ldots \ldots \ldots \ldots \ldots \ldots \ldots \ldots \ldots \ldots, 37$

3.6.3. Slag Characterization and General Observations .............. 39

3.6.4. Analysis of Crucible Corrosion During Stainless Steel Induction

3.7. Attainment of the Laboratory Test Work Goals $\ldots \ldots \ldots \ldots \ldots \ldots \ldots \ldots \ldots . \ldots \ldots \ldots$

\section{SECTION FOUR: STAINLESS STEEL PILOT AND COMMERCIAL SCALE}

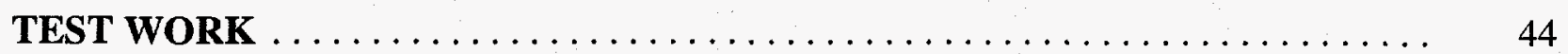

4.1. Pilot Scale Plasma and Vacuum Induction Melting Test Program . . . . . . . . . . . 44

4.1.1. Goals of the Pilot Scale Test Work $\ldots \ldots \ldots \ldots \ldots \ldots \ldots \ldots \ldots .44$

4.1.2. Plasma Pilot Scale Melt Test Program .................... 44

4.1.2.1. Description of the Melt Procedure .................... 44

4.1.2.2. Controlled Oxidation Melt with an Oxidizing Flux ............ 45

4.1.2.2.1. Initial Conditions for First Melt/flux Experiment ............ 45

4.1.2.2.2. Test Results ............................... 46

4.1.2.2.2.1. Metal Analyses ............................ 46

4.1.2.2.2.2. Slag Analyses $\ldots \ldots \ldots \ldots \ldots \ldots \ldots \ldots \ldots \ldots \ldots \ldots, 48$

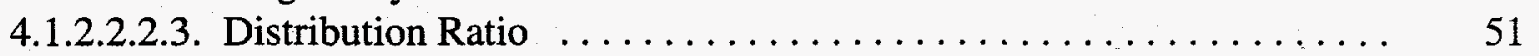

4.1.2.3 Second Controlled Oxidation Melt with an Oxidizing Flux ......... 51

4.1.2.3.1. Initial Conditions for Melt/flux Experiment $\ldots \ldots \ldots \ldots \ldots \ldots .51$

4.1.2.3.2. Test Results ............................... 52

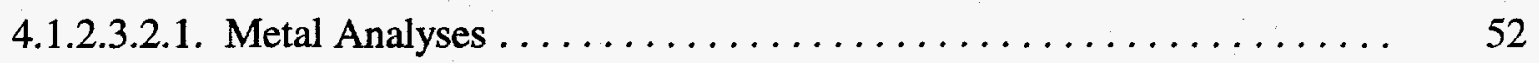

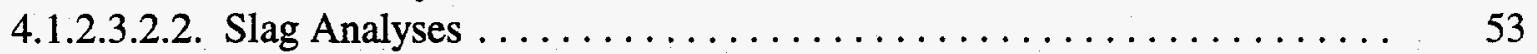

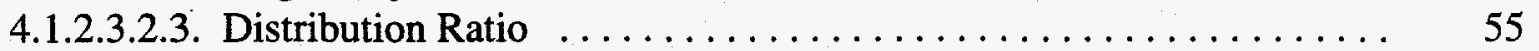

4.1.2.4. Controlled Oxidation Melt: $2 \% \mathrm{O}_{2} \ldots \ldots \ldots \ldots \ldots \ldots \ldots \ldots \ldots \ldots$

4.1.2.4.1. Initial Conditions for Melt: $2 \% \mathrm{O}_{2}$ Experiment $\ldots \ldots \ldots \ldots \ldots \ldots .56$

4.1.2.4.2. Test Results ................................. 56

4.1.2.4.2.1. Metal Analyses .............................. 56

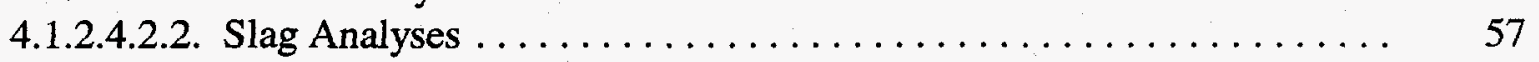

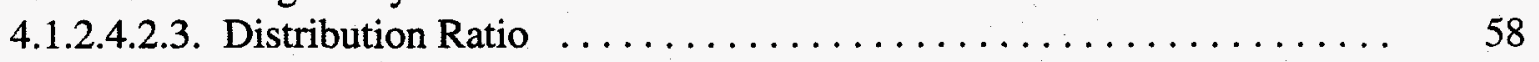

4.1.2.5. Controlled Oxidation Melt: $5 \% \mathrm{O}_{2} \ldots \ldots \ldots \ldots \ldots \ldots \ldots \ldots \ldots$

4.1.2.5.1. Initial Conditions for Melt: $5 \%$ O2 Experiment $\ldots \ldots \ldots \ldots \ldots \ldots .58$

4.1.2.5.2. Test Results ................................ 58

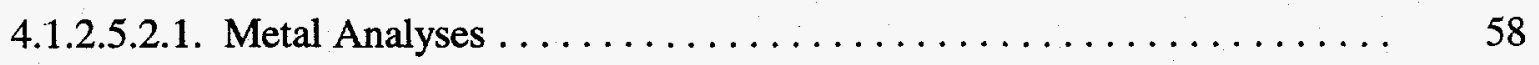

4.1.2.5.2.2. Slag Analyses ............................... 59

4.1.2.5.2.3. Distribution Ratio ......................... 60

4.1.2.6. Controlled Oxidation Melt: $5 \%$ and $10 \% \mathrm{O}_{2}$ (with a Refractory Lining) . 60 
4.1.2.6.1. Initial Conditions for Melt: $5-10 \% \mathrm{O}_{2}$ Experiment $\ldots \ldots \ldots \ldots \ldots . \ldots$

4.1.2.6.2. Test Results . . . . . . . . . . . . . . . . . . . . . . . . . . . . 60

4.1.2.6.2.1. Metal Analyses . . . . . . . . . . . . . . . . . . . . . 60

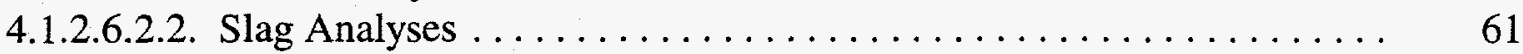

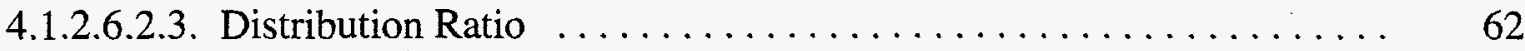

4.1.2.7. Controlled Oxidation Melt: $10 \% \mathrm{O}_{2} \ldots \ldots \ldots \ldots \ldots \ldots \ldots \ldots$

4.1.2.7.1. Initial Conditions for Melt: $10 \% \mathrm{O}_{2} \ldots \ldots \ldots \ldots \ldots \ldots \ldots \ldots \ldots \ldots$

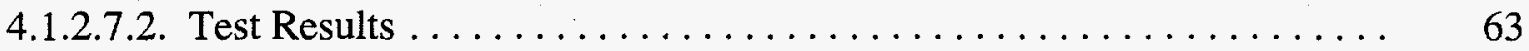

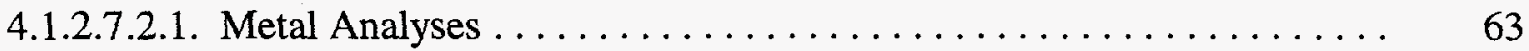

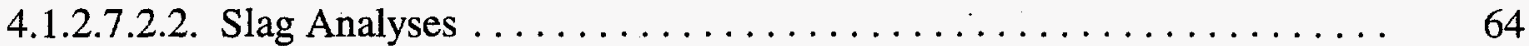

4.1.3. Vacuum Induction Pilot Scale Melt Program $\ldots \ldots \ldots \ldots \ldots \ldots \ldots$

4.1.3.1. Goals of the VIM Program . . . . . . . . . . . . . . . . . . 64

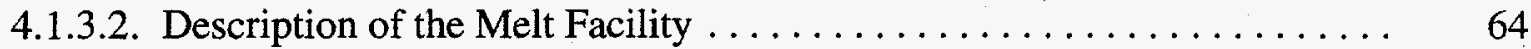

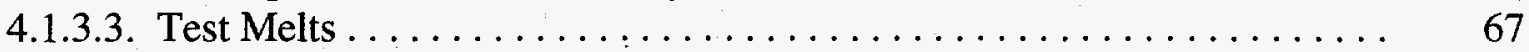

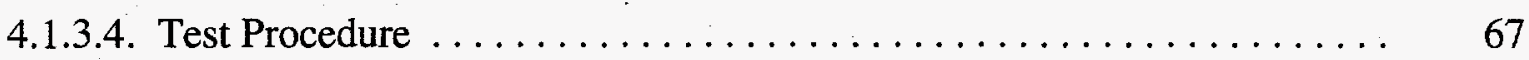

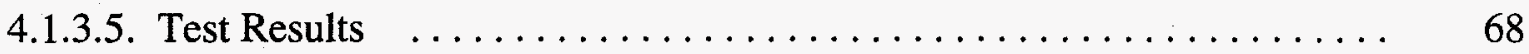

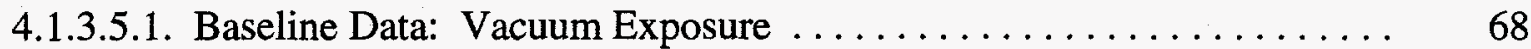

4.1.3.5.2. Gas Oxidizers: Carbon Dioxide or Air . . . . . . . . . . . . . . . . . 69

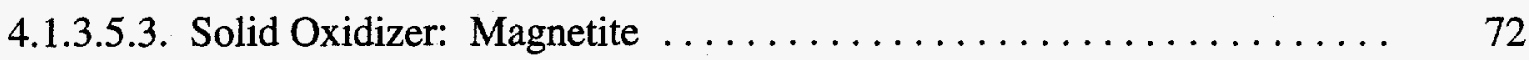

4.1.3.6. Summary of VIM Test Work . . . . . . . . . . . . . . . . 78

4.1.4. Attainment of Goals for the Pilot Scale Test Work . . . . . . . . . . . . 78

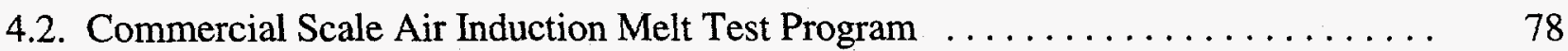

4.2.1. Goals of the Commercial Scale Air Induction Test Work . . . . . . . . . 78

4.2.2. AFFCO Demonstration Test ....................... . . 79

4.2.2.1. Initial Conditions for the AFFCO Test . . . . . . . . . . . . . . . 79

4.2.2.2. Test Results . . . . . . . . . . . . . . . . . . . . . . . 79

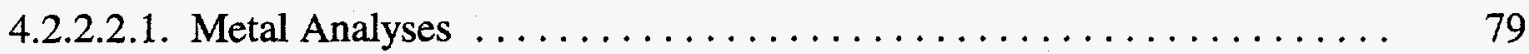

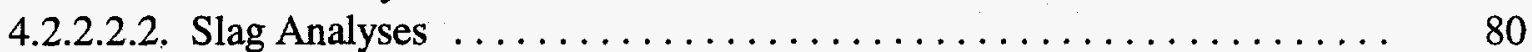

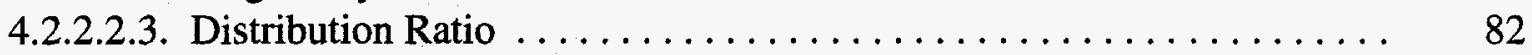

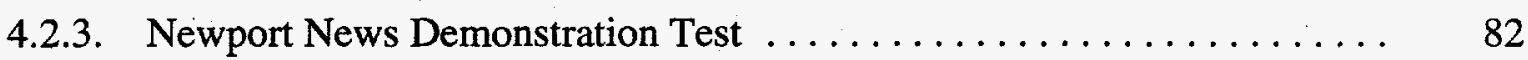

4.2.3.1. Initial Conditions for Newport News Test $\ldots \ldots \ldots \ldots \ldots \ldots \ldots \ldots \ldots$

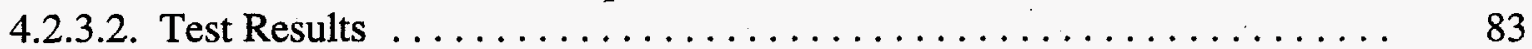

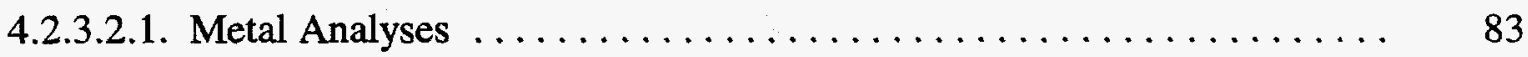

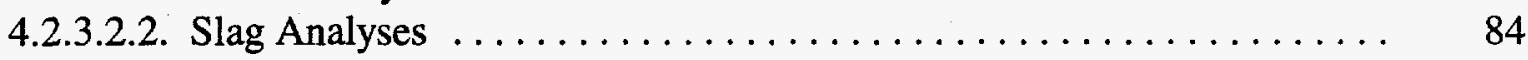

4.2.3.2.3. Distribution Ratio . . . . . . . . . . . . . . . . . 85

4.2.4. Attainment of Goals for the Commercial Scale Air Induction Melt Tests . 85

4.3. Stainless Steel Melt Program: Comparison of Results $\ldots \ldots \ldots \ldots \ldots \ldots \ldots \ldots$

SECTION FIVE: RECOMMENDATIONS FOR FURTHER STUDIES $\ldots \ldots \ldots .90$

SECTION SIX: REFERENCES $\ldots \ldots \ldots \ldots \ldots \ldots \ldots \ldots \ldots \ldots \ldots \ldots$ 


\section{LIST OF TABLES}

\section{SECTION ONE}

1.1. Radionuclides Found in Nuclear Power Reactors (Limited to Half Lives

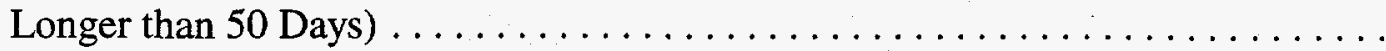

\section{SECTION TWO}

2.1. Surrogates Used for Radioactive Nuclides in High Temperature Studies . . . . . . 11

2.2. The Ten Radiologically Most Important Radionuclides at Different Times

for Surface Contamination for Decommissioning Waste $\ldots \ldots \ldots \ldots \ldots \ldots$

\section{SECTION THREE}

3.1. Surrogate Composition of the Master Ingot . . . . . . . . . . . . . . . . 27

3.2. Preparation of Stainless Steel Master Ingot: Metal Phase . . . . . . . . . . . . . 28

3.3. Preparation of Stainless Steel Master Ingot: Slag Phase . . . . . . . . . . . . . . . . 29

3.4. Preparation of Steel Master Ingot: Metal Phase $\ldots \ldots \ldots \ldots \ldots \ldots \ldots \ldots \ldots$

3.5. Preparation of Steel Master Ingot: Slag Phase . . . . . . . . . . . . . . . . 30

3.6. Experimental Conditions and Analytical Results for the Stainless Steel

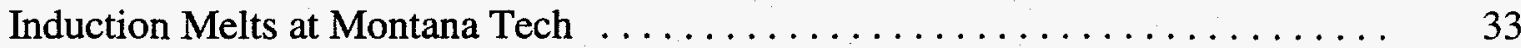

3.7 Experimental Conditions and Analytical Results for the Carbon Steel Induction

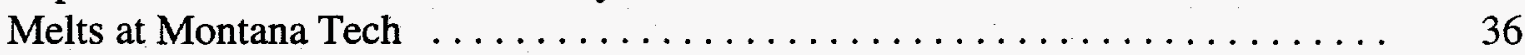

3.8. Slag Analyses for the Experimental Induction Stainless Steel Tests . . . . . . . 38

3.9. Results of the MgO Crucible Corrosion for the Stainless Steel Melt

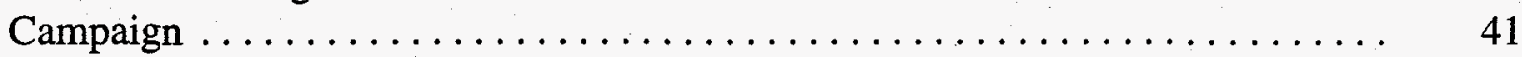

3.10. The Effects of Crucible Corrosion for the Steel Melt Campaign $\ldots \ldots \ldots \ldots \ldots 1$

\section{SECTION FOUR}

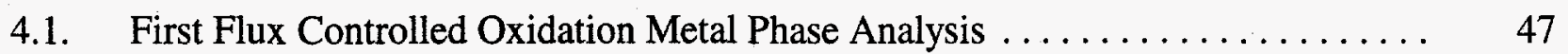

4.2. Flux Controlled Oxidation Slag Analysis . . . . . . . . . . . . . . . . . . . . 49

4.3. Distribution Ratios for the First Flux Controlled Oxidation Melt . . . . . . . . . 51

4.4. Metal Analyses for Second Flux Controlled Oxidation Melt . . . . . . . . . . 52

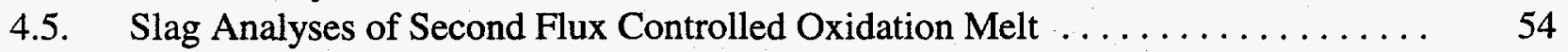

4.6. Distribution Ratios for the Second Controlled Oxidation Melt . . . . . . . . . . . 55

4.7. Metal Phase Analytical Results for the $2 \% \mathrm{O}_{2}$ Controlled Oxidation Melt ...... 56

4.8. Slag Analyses for $2 \% \mathrm{O}_{2}$ Controlled Oxidation Melt $\ldots \ldots \ldots \ldots \ldots \ldots \ldots$

4.9. Distribution Ratio Table for the $2 \% \mathrm{O}_{2}$ Controlled Oxidation Melt $\ldots \ldots \ldots \ldots .58$

4.10. Metal Analyses for $5 \% \mathrm{O}_{2}$ Controlled Oxidation Melt ............... 59

4.11. Slag Analyses for $5 \% \mathrm{O}_{2}$ Controlled Oxidation Melt $\ldots \ldots \ldots \ldots \ldots \ldots \ldots$

4.12. Distribution Ratio for the $5 \% \mathrm{O}_{2}$ Controlled Oxidation Melt $\ldots \ldots \ldots \ldots \ldots$ 
4.13. Metal Phase Analyses for 5 and $10 \% \mathrm{O}_{2}$ with Refractory Controlled

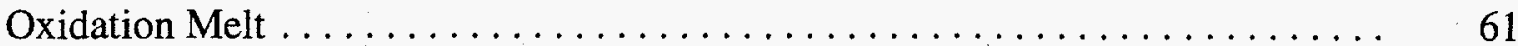

4.14. Slag Analyses for 5 and $10 \% \mathrm{O}_{2}$ Oxidation Melt with Refractory $\ldots \ldots \ldots 2$

4.15. Distribution Ratio Table for the 5 and $10 \% \mathrm{O}_{2}$ Controlled Oxidation Melt $\ldots \ldots .62$

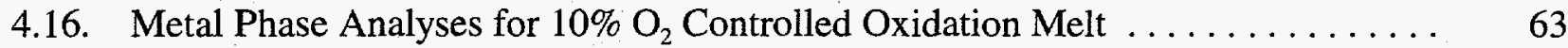

4.17. VIM 1: Vacuum Induction Melting of Stainless Steel . . . . . . . . . . . . . . . 69

4.18. VIM 2: Vacuum Induction Melting of Stainless Steel in the Presence of Carbon Dioxide . . . . . . . . . . . . . . . . . . . . . 70

4.19. VIM 3: Vacuum Induction Melting of Stainless Steel in the Presence of Carbon Dioxide ............................. 71

4.20. VIM 4: Vacuum Induction Melting of Stainless Steel in the Presence of

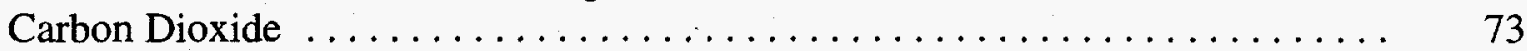

4.21. VIM 5: Vacuum Induction Melting of Stainless Steel in the Presence of Air . . . . 74

4.22. VIM 6: Vacuum Induction Melting of Stainless Steel Using Magnetite as an

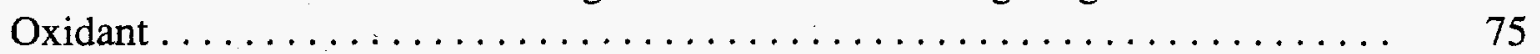

4.23. VIM 7: Vacuum Induction Melting of Stainless Steel Using Magnetite as an

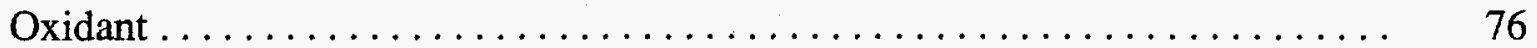

4.24. VIM 8: Vacuum Induction Melting of Stainless Steel Using Magnetite as an

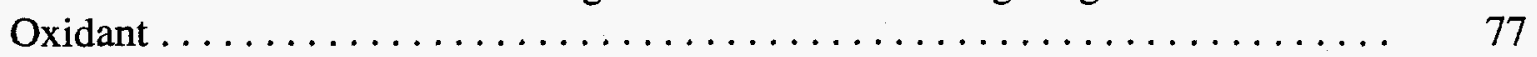

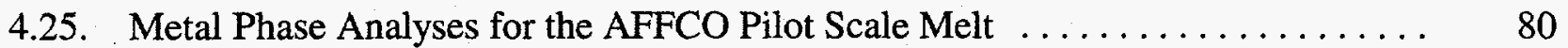

4.26. Slag Analyses of the AFFCO Pilot Scale Melt $\ldots \ldots \ldots \ldots \ldots \ldots \ldots \ldots \ldots \ldots$

4.27. Distribution Ratio Table for the AFFCO Pilot Scale Oxidation Induction Melt . . . 82

4.28. Metal Phase Analyses for the NNS Pilot Scale Induction Melt . . . . . . . . 83

4.29. Slag Analyses for the NNS Pilot Scale Induction Melt . . . . . . . . . . . . . . . 84

4.30. Distribution Ratio Table for the NNS Pilot Scale Induction Oxidation Melt . . . . 85

4.31. Compilation of Pilot Scale and Commercial Scale Melt Tests: Metal Phase Analyses .................................. 85

4.32. Compilation of Pilot Scale and Commercial Scale Melt Tests: Slag Analyses . . . . 88 


\section{LIST OF FIGURES}

\section{FIGURE}

\section{SECTION TWO}

2.1. Ellingham Diagram for Stainless Steel Constituents ................ 16

2.2. Ellingham Diagram for Slag Constituents $\ldots \ldots \ldots \ldots \ldots \ldots \ldots \ldots \ldots, 16$

2.3. Ellingham Diagram for Surrogate Constituents .................. 17

2.4. Free Energy of Formation for Lanthanum Oxide Compared to Steel Making

Constituents ..................................

\section{SECTION THREE}

3.1. Photograph of the Pilot Scale Feedstock Preparation Sequence: Welded

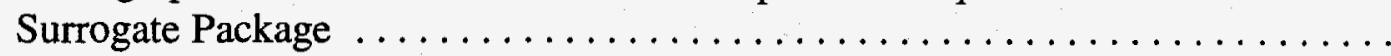

3.2. Photograph of the Pilot Scale Feedstock Preparation Sequence: Surrogate

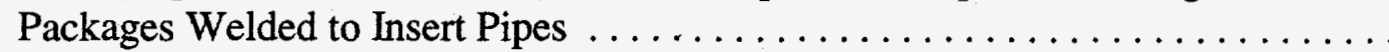

3.3. Photograph of the Pilot Scale Feedstock Preparation Sequence: Final

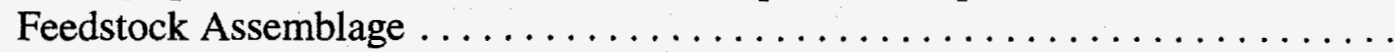

3.4. Schematic Diagram Depicting the Numbering Sequence Designation and Elemental Analysis Locations of Samples from the Master Ingot . . . . . . . . . 26

3.5. Photograph of the Sectioned Master Ingot . . . . . . . . . . . . . . . . 26

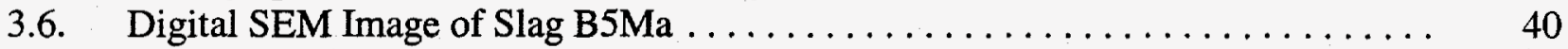

\section{SECTION FOUR}

4.1. Slag Collection Points from the Retech Plasma Furnace .............. 48

4.2. Overhead View of the Retech $125 \mathrm{KW}$ VIM Showing Operator Console, View Ports, Gas Lance, and Alloy Feeder .................... 66

4.3. The Retech VIM with the Door Open and a Mold Box in Place ........... 66 



\title{
DECONTAMINATION AND DECARBURIZATION OF STAINLESS AND CARBON STEEL BY MELT REFINING
}

\author{
SECTION ONE
}

INTRODUCTION

\subsection{BACKGROUND}

With many nuclear reactors and facilities being decommissioned in the next ten to twenty years the concern for handling and storing Radioactive Scrap Material (RSM) is growing. Upon direction of the DOE Office of Environmental Restoration and Waste Management, Lockheed Idaho Technologies Company (LITCO), formerly Westinghouse Idaho Nuclear Company (WINCO), is developing technologies for the conditioning of spent fuels and high-level wastes for interim storage and long term repository acceptance, including the recycling of RSM for beneficial re-use within the DOE complex (T.E. Bechtold, 1993). The current RSM inventory for the Idaho National Engineering Laboratory (INEL) is estimated at 1.0 million kilograms of which 175,900 kilograms consists of iron or carbon steel, and 294,300 kilograms of stainless steel. RSM steel and stainless steel projections for Decontamination and Decommissioning (D\&D) for the INEL are estimated to be 23,759,600 kilograms and 37,613,100 kilograms, respectively. (T.E. Bechtold, 1993). In a recent report which addressed the entire DOE complex and the nuclear power industry, Nichols estimated approximately $109,000,000$ kilograms (120,000 tons) of RSM would be available annually for recycle or burial beginning in 1999-2000. (F. Nichols, 1995)

In February, 1993, WINCO awarded a task order for the development and demonstration of technology for the decontamination of stainless steel RSM to Montana Tech of the University of Montana. (Since October, 1995, management of the INEL Metal Recycle program has changed from WINCO to Lockheed Idaho Technologies Company (LITCO)). The contract objectives for Montana Tech are further described in Sections 2.1.

\subsection{RADIONUCLIDES IN NUCLEAR POWER REACTORS}

The contamination present in RSM can be either volumetric or surface contamination. Certain elements present in both stainless and carbon steel can become activated from the neutron flux during normal reactor operations, thus causing volumetric contamination. Surface contamination is often due to radioactive elements from reactor and/or spent fuel storage environments that are present in "Crud" (Atteridge, 1994, Dyer, 1994) that is deposited or forms on the surface. This "Crud" is a corrosion product from within the reactor vessel or from a "leaking" nuclear fuel rod.

In a recent report, Dyer and others listed types of radioactive contaminants possible in nuclear reactor systems. Dyer assumes that 1000 days would be required before RSM could enter the recycling process; therefore, the removal of radionuclides with half-lives less than 50 days should 
not be considered because radionuclide reduction of over a million times (9.54E-7) will occur in a period of 1000 days. (N.C. Dyer, 1994) The radionuclides of concern in nuclear power reactors (half-lives longer than 50 days) for decontamination are presented in Table 1.1. These nuclides are separated into three groups: gamma emitters, non-gamma and low-energy gamma emitters, and transuranics.

TABLE 1.1. RADIONUCLIDES FOUND IN NUCLEAR POWER REACTORS (LIMITED TO HALF-LIVES LONGER THAN 50 DAYS), Dyer (1994)

\begin{tabular}{||l|l|l||}
\hline \multicolumn{1}{|c|}{ NUCLIDES } & \multicolumn{1}{|c|}{$\begin{array}{c}\text { HALF-LIFE } \\
\text { (DAYS) }\end{array}$} & \multicolumn{1}{c|}{ MODE OF PRODUCTION } \\
\hline \hline FOR GAMMA EMITTERS: & \multicolumn{1}{|c||}{} \\
\hline \hline Mn-54 & $3.1 \mathrm{E}+2$ & Activation of iron \\
\hline Co-57 & $2.7 \mathrm{E}+2$ & Activation of nickel \\
\hline Co-58 & $7.1 \mathrm{E}+1$ & Activation of nickel \\
\hline Co-60 & $1.9 \mathrm{E}+3$ & Activation of cobalt \\
\hline $\mathrm{Zn}-65$ & $2.4 \mathrm{E}+2$ & Activation of zinc \\
\hline $\mathrm{Kr}-85$ & $3.9 \mathrm{E}+3$ & Fission/Fuel \\
\hline $\mathrm{Zr}-95$ & $6.4 \mathrm{E}+1$ & Fission/Fuel and Activation of Zr-94 \\
\hline Nb-94 & $7.4 \mathrm{E}+6$ & Fission/Fuel then Activation of Nb-93 \\
\hline Ru-106 \& D & $3.7 \mathrm{E}+2$ & Fission/Fuel \\
\hline Ag-108m & $4.6 \mathrm{E}+4$ & Activation of silver \\
\hline Ag-110m & $2.5 \mathrm{E}+2$ & Activation of silver \\
\hline Sb-124 & $6.0 \mathrm{E}+1$ & Activation of antimony \\
\hline $\mathrm{Sb}-125$ & $1.0 \mathrm{E}+3$ & Activation of tin \\
\hline Cs-134 & $7.5 \mathrm{E}+2$ & Fission/Fuel then Activation of Cs-133 \\
\hline Cs-137 & $1.1 \mathrm{E}+4$ & Fission/Fuel \\
\hline Ce-144 \& D & $2.8 \mathrm{E}+2$ & Fission/Fuel \\
\hline Eu-152 & $5.0 \mathrm{E}+3$ & Fission/Fuel \\
\hline Eu-154 & $3.2 \mathrm{E}+3$ & Fission/Fuel \\
\hline & & \\
\hline & & \\
\hline
\end{tabular}




\begin{tabular}{|l|l|l||}
\hline \multicolumn{1}{|c|}{ NUCLIDES } & \multicolumn{1}{|c|}{$\begin{array}{c}\text { HALF-LIFE } \\
\text { (DAYS) }\end{array}$} & \multicolumn{1}{|c|}{ MODE OF PRODUCTION } \\
\hline \hline Eu-155 & $1.8 \mathrm{E}+3$ & Fission/Fuel \\
\hline \hline \multicolumn{2}{|c|}{ FOR NON-GAMMA OR LOW-ENERGY GAMMA EMITTERS: } \\
\hline \hline H-3 & $4.5 \mathrm{E}+3$ & Activation of deuterium or lithium \\
\hline C-14 & $2.1 \mathrm{E}+6$ & Activation of nitrogen \\
\hline S-35 & $8.7 \mathrm{E}+1$ & Activation of sulfur or chlorine \\
\hline Ca-45 & $1.6 \mathrm{E}+2$ & Activation of calcium \\
\hline Fe-55 & $9.9 \mathrm{E}+2$ & Activation of iron \\
\hline Ni-59 & $2.7 \mathrm{E}+7$ & Activation of nickel \\
\hline Ni-63 & $3.7 \mathrm{E}+4$ & Activation of nickel \\
\hline Sr-89 & $5.1 \mathrm{E}+1$ & Fission/Fuel \\
\hline Sr-90 \& D & $1.0 \mathrm{E}+4$ & Fission/Fuel \\
\hline Y-91 & $5.9 \mathrm{E}+1$ & Fission/Fuel \\
\hline Nb-93m & $5.3 \mathrm{E}+3$ & Fission/Fuel \\
\hline Mo-93 & $1.3 \mathrm{E}+6$ & Activation of molybdenum \\
\hline Tc-99 & $7.8 \mathrm{E}+7$ & Fission/Fuel \\
\hline I-129 & $5.7 \mathrm{E}+9$ & Fission/Fuel \\
\hline Pm-147 & $9.6 \mathrm{E}+2$ & Fission/Fuel \\
\hline \hline FOR TRANSURANICS: & \\
\hline \hline PU-238 & $3.2 \mathrm{E}+4$ & Fission/Fuel \\
\hline Pu-239 & $8.8 \mathrm{E}+6$ & Fission/Fuel \\
\hline Pu-240 & $2.4 \mathrm{E}+6$ & Fission/Fuel \\
\hline Pu-241 & $5.3 \mathrm{E}+3$ & Fission/Fuel \\
\hline Am-241 & $1.6 \mathrm{E}+5$ & Fission/Fuel \\
\hline Cm-242 & $1.6 \mathrm{E}+2$ & Fission/Fuel \\
\hline Cm-244 & $6.6 \mathrm{E}+3$ & Fission/Fuel \\
\hline \hline
\end{tabular}


T.E. Bechtold (1994) noted that the allowable release of decontaminated materials has not been fully established at the present time, "The Nuclear Regulatory Commission (NRC) attempted to initiate a de minimus free release policy for decontaminated metals, but public opposition to the policy has prevented any free release of materials with detectable radioactivity. A court tort deciding in favor of a claim for damages resulting from radiation exposure could establish strict liability, and hold the original generator liable for damages. The risk of this type of ruling could make NRC licensees extremely cautious about releasing contaminated material for conversion to consumer products. ...In view of continued public resistance to participation in efforts to frame clear and explicit regulatory guidance, and in light of the potential for product liability, the best available option for RSM recycle would appear to be the fabrication of products which would remain under DOE or NRC operational controls." (T.E. Bechtold, 1994)

\subsection{PUBLICATIONS RESULTING FROM THIS STUDY}

The reader is referred to the following publications that resulted from the steel and stainless studies (listed in alphabetical order):

- $\quad$ Paolini, D.J., "Decontamination of Metals by Melt Refining/Slagging", MSc. Thesis in Metallurgical Engineering at Montana Tech of the University of Montana, 128 p., May 1995.

- Weldon, T.A., "Decontamination of Metals by Melt Refining/Slagging", MSc. Thesis in Metallurgical Engineering at Montana Tech of the University of Montana, 131 p., June 1994.

- Webber, D., "Decontamination and Decarburizationof Stainless Steel by Vacuum Induction Melting," MSc.Thesis in Metallurgical Engineering at Montana Tech of the University of Montana, In Progress, 1996.

- Worcester, S.A., Twidwell, L.G., Paolini, D.J., Weldon, T.A., Mizia, R.E. (Ed.), "Decontamination of Metals by Melt Refining/Slagging-An Annotated

Bibliography", WINCO-1138, INEL-DOE, 89 p., 1993.

- Worcester, S.A., Twidwell, L.G., Paolini, D.J., Weldon, T.A., Mizia, R.E. (Ed.), "Decontamination of Metals by Melt Refining/Slagging: First Year Progress Report", WINCO-1198, INEL-DOE, 47 p., 1994.

- Worcester, S.A., Twidwell, L.G., Paolini, D.J., Weldon, T.A., Mizia, R.E., "Decontamination of Metals by Melt Refining/Slagging", Second International Conference on Materials Engineering for Resources, ICMR'94 AKITA, October 12-14,1994, Society of Mat'ls Engr for Resources of Japan and Res. Inst. of Nat. Resources, pp 62-75, 1994. 
- Worcester, S.A., Twidwell, L.G., Paolini, D.J., Weldon, T.A., Mizia, R.E., "Decontamination of Metals by Melt Refining/Slagging", Proc. Vacuum Metallurgy Conf. on Liquid Metal Processing and Casting, Sante Fe, N.M., Sept. 11-14, 1994, 14 p., 1994.

- Worcester, S.A., Twidwell, L.G., Paolini, D.J., Weldon, T.A., Mizia, R.E. (Ed.), "Decontamination of Metals by Melt Refining/Slagging: An Annotated Bibliography Update on Stainless Steel and Steel," DOE De-AC07-94ID13223, INEL-95/0123, 1995.

- Worcester, S. A., Twidwell, L.G., Webber, D. Mizia, R. E. "Decontamination and Decarburization of Stainless Steel by Vacuum Induction Melting," accepted for presentation at "Spectrum'96 Nuclear and Hazardous Waste Management International Topical Meeting", Seattle, WA, August 1996.

\subsection{PUBLICATIONS RESULTING FROM COMPANION STUDIES}

The reader is also referred to the following publications that resulted from other INEL Metal Recycle Program-sponsored programs (listed in alphabetical order)

- $\quad$ Atteridge, D.G., Buckentin, J., J. Carter, Davis, H.L., Devletian, J.H., Scholl, M.R., Turpin, R.B., Webster, S.L., Mizia, R.E. (Ed.), "Refining Technology for the Recycling of Stainless Steel Radioactive Scrap Metals: FY 94 Bi-Annual Report," INEL-DOE, WINCO-1224, 97 p., 1994.

- $\quad$ Bechtold, T.E. (Editor), "WINCO Metal Recycle Annual Report, FY 1993," INEL-DOE, WINCO-1172, 77 p., 1993.

- $\quad$ Bechtold, T. E. (Editor), "INEL Metal Recycle, Annual Report" INEL-94/0067, September 1994.

- $\quad$ Buckentin, J. M. R., "Melt Decontamination of Radioactive Stainless Steel by Electroslag Remelting", PhD. Thesis in Materials Science at Oregon Graduate Institute of Science and Technology, 241 p., March 1996

- $\quad$ Dyer, N.C., Bechtold, T.E. (Editor), "Radionuclides in United States Commercial Nuclear Power Reactors", WINCO-1191, INEL-DOE, 26 p., 1994.

- $\quad$ Frost, R. H., "Refining Technologies for Radioactive Stainless Steel Scrap", Final Report Contract No. C86-110877-009, Colorado School of Mines, 61 p., 1996. 


\title{
DECONTAMINATION AND DECARBURIZATION OF STAINLESS STEEL AND
}

CARBON STEEL BY MELT REFINING

\author{
SECTION TWO
}

\author{
RESEARCH PROGRAM
}

\subsection{OBJECTIVES}

General objectives of the Montana Tech research program included: a literature survey, laboratory scale melt refining experiments to optimize decontaminating slag compositions, analysis of preferred melting techniques, coordination of pilot scale and commercial scale melt demonstrations, and providing pilot and commercial scale quantities of surrogate-containing steels for subsequent demonstration programs. Specific objectives of the Montana Tech research program included the following components:

- Review the literature as it relates to decontamination of radioactive elements from carbon and stainless steel. Prepare annotated summaries of the published literature. (Worcester, 1993 and 1995)

- Evaluate melt technologies and chose those appropriate for the present study.

- Design appropriate slag formulations for use in a laboratory experimental study.

- Investigate the usefulness of calculational programs to predict the thermodynamic distribution of species between gaseous and condensed phases as a function of a number of system variables, e.g., temperature, impurity content, selected additive flux constituents, and gas composition.

- Conduct laboratory experimental studies and thermodynamic calculations to optimize the selection of appropriate slag formulations.

- Conduct laboratory experimental studies and thermodynamic calculations to optimize the selection of appropriate refractories for the selected slag formulation(s).

- Apply the results of the laboratory research program to pilot scale studies at commercial facilities to demonstrate effective decontamination technology(s) for slag/melt refining. (Worcester, et al, 1994) 


\subsection{LITERATURE SURVEY/ANNOTATION FOR STAINLESS AND CARBON STEEL}

Two separate literature annotations have been completed by the Montana Tech research team. The first was an extensive search of 12 databases, reviewing over 280 published literature reports pertaining to the decontamination refining of stainless steel, annotating the articles and publishing the results (Worcester, 1993). The second literature evaluation consisted of reviewing, annotating, and publishing results for steel decontamination refining, and updating the stainless steel annotation from 1993 to 1995 (Worcester, 1995). Relevant comments resulting from the literature reviews are presented below.

A conclusion resulting from the review of published literature by Worcester $(1993,95)$ was that test work (both bench scale and larger scale) demonstrated that slagging decontamination of uranium and plutonium from steel and stainless steel is an effective treatment technology. Laboratory test work performed at Montana Tech and large scale test work supervised by Montana Tech personnel (Worcester, et al, 1994) have further demonstrated (using surrogates for the radioactive nuclides) effective decontamination to concentrations less than one part per million using induction melting (in air and in a vacuum). Other test work in associated programs included; electroslag melting laboratory test work performed at the Oregon Graduate Institute (Atteridge, et al, 1994; Buckentin, 1996) and at the Colorado School of Mines (Frost, 1996).

Based on trends found in the literature, basic calcium-aluminum-silicate slags (with additives such as calcium fluoride or ferric oxide) appeared to be effective RSM decontaminators. However, the recent work of Worcester (1994), Weldon (1994) and Paolini (1995) demonstrated that flux composition is not very important when the decontamination is conducted in refractory-lined induction melting furnaces.

From the literature review it appears that removal of most radionuclides by slagging and volatilization holds good possibilities for the treatment of steel scrap. The same slagging/volatilization possibilities appear to exist for stainless steel, except for the specific elements that constitute stainless steel. Radionuclides of the major consitutents (iron, cobalt, nickel, chromium) will be retained to a large degree in the metal product.

Tritium removal was not considered in the keyword search nor was analytical data provided in any of the publications reviewed. This issue was the subject of a joint LITCO/Savannah River Technical Center (SRTC) research initiative and the reader is referenced to that initiative. (Imrich, 1994)

The technological community has selected two technologies for melt/consolidation of RSM, coreless induction and electric arc furnace (EAF) melting. The choice between these two technologies involves many factors. The main factors favoring coreless induction include better melt agitation, easier fume control, and rapid heat up. These factors are particularly important when considering an initial consolidation/homogenization melt of RSM, and are the primary reasons why induction melting was selected for most of the "large scale" RSM melting described in the literature. On the other hand, the EAF provides lower cost as heat sizes increase, accommodates larger scrap section 
sizes, allows for easier modification of melt composition, and provides a greater margin of reliability and safety because of the absence of the water cooled induction coil. According to Reimann (1991), an induction furnace produces only $20 \%$ as much effluent dust as an EAF of similar capacity. In the authors opinion, the reduction of effluent dust should be a major factor in furnace selection. This is of significance when designing a capture system which will control the dispersal of a significant portion of the long-lived radionuclides (e.g., Cs-137).

It appears quite obvious that melt decontamination alone will not provide RSM which qualifies for free release to the private sector, particularly if the trend reflected in Europe in 1989 (Janberg, 1990) toward lowering free release limits from $3.7 \mathrm{~Bq} / \mathrm{g}$ to $0.1 \mathrm{~Bq} / \mathrm{g}$ continues. Essentially none of the products (discussed in publications describing large scale melting treatment) could be released under the criteria established in Europe in 1989. It is suggested that free or controlled release is not necessary; and that consolidation of RSM and removal of volatile and easily oxidized radionuclides could be accomplished in DOE-controlled melting facilities. Melt consolidated and characterized RSM from these facilities could then be released, on a controlled basis, to the steel industry for efficient incorporation into large heats for manufacture of nuclear waste or nuclear fuel storagecontainers. (Worcester, et al, 1994) In addition, elimination of volatile and easily oxidized elements from recycle heats minimizes the problems involved in fabrication of useful components such as waste containers and canisters.

The availability of stainless steel RSM at INEL and other DOE sites and the need for stainless steel for waste or nuclear fuel storage canisters present a unique opportunity. Methods for consolidating stainless steel RSM can be developed on a commercial scale while developing protocol for disposal of carbon steel scrap at a later date. Carbon steel might also be combined with characterized nickel RSM to produce additional quantities of stainless steel for use within the DOE program (Mizia, 1993). This approach has been pursued by Manufacturing Sciences Corporation. (Nichols, 1994) Montana Tech is currently involved in a program with MSE, Inc to demonstrate the conversion of surrogate-containing carbon steel scrap into stainless steel meeting low carbon requirements.

Analysis of the literature suggests the following approach:

- Decontaminate and melt stainless steel RSM into heats of sufficient size to minimize radionuclide characterization and analytical costs while casting the material into suitable shapes for recycle into a limited release remelt program. These products could be used to fabricate components for the nuclear industry.

- $\quad$ Such an approach would provide volume reduction while establishing protocol for at least limited release into the commercial scrap market. One of the problems associated with trying to do on-site casting of stainless heats for fabrication into canisters is the small heat size inherent in such an application. Small heat sizes significantly drive up production costs while increasing certification costs and complexity without improving quality. 
Even if the largest U.S. RSM furnaces were used for ingot casting, heat size would only be 20 tons. Fabrication and quality control costs for such small heats would be prohibitive. On the other hand, if characterized first melt RSM ingots were released to a commercial stainless melter/fabricator for use as scrap addition to heats, quality could be improved, with minimal risk, by relying on the melting and fabrication expertise of the steel industry.

The program suggested in the original bibliography (Worcester, 1993) follows:

- $\quad$ "Decontaminate and melt RSM within the DOE complex into a configuration which is acceptable for use in the commercial scrap market, for use as shielding blocks, or for land disposal. Melting parameters would be optimized for transfer of radionuclides into slag and fume, homogenizing the melt, and minimizing slag inclusions.

- Release heats which meet release specifications to a commercial stainless melter/fabricator for combination with non-contaminated melt stock into large heats for fabrication into DOE program products. These products might include 55-gallon drums for low-level nuclear waste disposal, Hot Isostatic Pressed (HIP) canisters for Idaho Chemical Processing Plant (ICPP) waste immobilization, overpack canisters for ICPP-HIP canisters, and multipurpose containers for storage of spent nuclear fuel.

- Use non-qualifying heats for internal use, land disposal, or remelting within the DOE complex. Remelting might involve further melt refining, possibly by induction ladle metallurgy as proposed by Reimann (Reimann, 1991) or electroslag melting." (Worcester, et al, 1993)

An alternatively realistic approach is the establishment of a regional or national RSM processing center within the DOE complex equipped to decontaminate, melt refine, cast, roll, and final fabricate the hardware required for nuclear waste disposal.

This approach is supported by the following observations:

- $\quad$ Free release requirements will become tighter with time.

- The steel industry is unlikely to accept RSM-derived material for input to conventional facilities.

- It is unlikely available quantities of RSM will justify more than one large-scale processing facility. Canister quality will be enhanced by utilization of larger equipment. Quality and certification costs for containers will be significantly reduced on large heats while real 
quality will be improved. Consolidation of stainless steel RSM will undoubtedly introduce some carbon pickup, necessitating carbon blowdown in the VIM, as developed in this program, or secondary refining techniques such as AOD or VOD for economical processing of low carbon stainless steel. Such refining will not be necessary for carbon steel.

- Some radionuclides will not be removed by any practical melting process known today (e.g., $\mathrm{Fe}, \mathrm{Co}, \mathrm{Mn}$ ).

- Stainless steel scrap can be consolidated at a cost, at least, on a breakeven basis ( $\$ 400 /$ ton) with commercial market stainless steel (disregarding burial costs for RSM). Mizia (1994) analyzed allowable costs for stainless RSM recycle. In the most likely scenario, burial costs were pegged at $\$ 668 /$ cubic foot. A savings of $\$ 35,000$ per 20 short ton (empty weight) canister was estimated. This estimate allowed a $\$ 2.10 / \mathrm{lb}$ tolling charge and a $15 \%$ premium for fabrication of the canister from RSM. Projected savings are highly dependent upon burial costs. A recent report by Nichols of Manufacturing Sciences Corporation (as a subcontractor to MSE, Inc. (Nichols, 1995)) estimates RSM production costs at \$1130/ton for hot rolled sheet. Assuming a generator transfer charge of $\$ 1500 /$ ton, and an RSM product sales price of $70 \%$ of commercial value, Nichols estimated a 22 to $44 \%$ return on investment for a 30,000 tpy dedicated RSM "minimill."

\subsection{SURROGATES}

Surrogates used in the present study included an isotopic mixtures of cerium, strontium, neodymium, lanthanum, and cesium. Cerium and strontium represent radioactive isotopes of these elements, while neodymium, lanthanum, and cerium were chosen to simulate the metal/slag distribution characteristics of uranium, plutonium, radioactive isotopes of the lanthanide elements, and the other actinide elements. (Worcester, et al, 1994)

Elemental surrogate concentrations were added at 0.10 weight percent additions ( $1000 \mathrm{ppm})$. The surrogate concentration level achieved in the master alloys were in general in the range of 300-500 ppm. (Worcester, et al, 1994)

There have only been a limited number of test programs that have used surrogates to simulate the distribution of radioactive nuclides during melt refining. However, a few studies have been identified that relate directly to the present project. The literature that has been identified is presented in Table 2.1. 
TABLE 2.1. SURROGATES USED FOR RADIOACTIVE NUCLIDES IN HIGH TEMPERATURE STUDIES

\begin{tabular}{|c|c|c|c|}
\hline $\begin{array}{c}\text { Radionuclide } \\
\text { or Oxide }\end{array}$ & Surrogate & Comment & Reference \\
\hline $\mathrm{PuO}_{2}$ & $\mathrm{HfO}_{2}$ & $\begin{array}{l}\text { Simulate plutonium oxide } \\
\text { in electroslag melting }\end{array}$ & Ochiai (1982) \\
\hline $\begin{array}{l}\text { Fe-55, Ni-59, } \\
\mathrm{Ni}-63\end{array}$ & Co-60 & $\begin{array}{l}\text { Melt experiments with } \\
\beta, \gamma \text {-contaminated } \\
\text { material }\end{array}$ & Schuster (1990) \\
\hline $\mathrm{PuO}_{2}$ & $\mathrm{UO}_{2}$ & $\begin{array}{l}\text { Resistance heating \& arc } \\
\text { melting techniques }\end{array}$ & Levitz (1975) \\
\hline $\mathrm{PuO}_{2}$ & $\begin{array}{l}\text { Rare Earth Oxides of } \\
\text { Dysprosium, Terbium, } \\
\text { Ytterbium }\end{array}$ & $\begin{array}{l}\text { Simulate plutonium in } \\
\text { soils in vitrification study }\end{array}$ & Stoots $(1990)$ \\
\hline $\begin{array}{l}\mathrm{PuO}_{2} \text { and } \\
\text { Transuranic } \\
\text { Oxides }\end{array}$ & Dysprosium Oxide & $\begin{array}{l}\text { Incinerator tests and } \\
\text { Glove box tests }\end{array}$ & $\begin{array}{l}\text { Shaw }(1988) \text { as } \\
\text { referenced by } \\
\text { McAtee (1991); } \\
\text { Hooker (1981); } \\
\text { Shaw (1988) } \\
\end{array}$ \\
\hline $\mathrm{PuO}_{2}$ & $\begin{array}{l}\text { Rare Earth Oxides of } \\
\text { Dysprosium, Neodymium, } \\
\text { Ytterbium, Cerium }\end{array}$ & $\begin{array}{l}\text { Vitrification and slagging } \\
\text { in silicate melts }\end{array}$ & $\begin{array}{l}\text { Bergsman (1991) } \\
\text { as referenced by } \\
\text { McAtee (1991) }\end{array}$ \\
\hline $\mathrm{PuO}_{2}$ & Dysprosium Oxide & $\begin{array}{l}\text { Vitrification and slagging } \\
\text { in silicate melts }\end{array}$ & $\begin{array}{l}\text { Weidner (1991) as } \\
\text { referenced by } \\
\text { McAtee (1991) }\end{array}$ \\
\hline $\mathrm{PuO}_{2}$ & $\begin{array}{l}\text { All Rare Earth Oxides } \\
\text { (Especially Cerium) }\end{array}$ & $\begin{array}{l}\text { Based on high } \\
\text { temperature chemistry } \\
\text { considerations }\end{array}$ & McAtee (1991) \\
\hline $\mathrm{PuO}_{2}$ & Cerium Oxide & $\begin{array}{l}\text { Simulate plutonium oxide } \\
\text { distribution during } \\
\text { plasma melting of } \\
\text { contaminated soils }\end{array}$ & Whitworth (1993) \\
\hline
\end{tabular}

Various substitutes for radioactive nuclides have been selected, e.g.,

- Ochiai, et al (1982) investigated the distribution of $\mathrm{HfO}_{2}$ (as a surrogate for $\mathrm{PuO}_{2}$ ) in an electroslag melting study. They determined that the best initial slag was composed of $47 \% \mathrm{CaO}, 48 \% \mathrm{Al}_{2} \mathrm{O}_{3}, 5 \% \mathrm{~B}_{2} \mathrm{O}_{3}$ (the silica content of the slag rose to approximately $20 \%$ after repeated exposure). The hafnium distributed primarily, $96 \%$, to the slag phase. The final ingot contained $2.53 \mathrm{ppb}$ hafnium. 
- McAtee (1991) has reviewed the high temperature chemistry of plutonium and the rare earths. He quotes the work of Shaw (1988a, 1988b), Hooker (1981), Weidner (1991), and Bergsman (1991) who have used rare earth oxides as surrogates for plutonium oxide. Shaw (1988a) and Hooker have reported the use of dysprosium oxide in incineration tests. Shaw also reported the use of dysprosium oxide in a glove box scale study on excavated buried transuranic wastes. Bergsman (1991) and Weidner (1991) used rare earth oxides to simulate plutonium in in-situ vitrification studies. Weidner used dysprosium oxide in test work on in-situ vitrification of basaltic melts and Weidner found that the simulates dysprosium, neodymium, ytterbium and cerium oxides were uniformly distributed in the silicate melt product at approximately uniform concentrations.

- Stoots (1990) recommended the use of rare earth oxides of dysprosium, terbium and ytterbium as simulates for plutonium oxide in soils. This was a work plan for in-situ vitrification studies. Experimental data were not yet published at the time of this report.

- Whitworth is presently conducting a study at MSE in Butte, MT to investigate the distribution of plutonium oxide during the plasma melting of contaminated wastes and soils. Cerium oxide is being used as the surrogate for plutonium oxide. Results of early work are published. (Whitworth, et al, 1992)

- Schuster (1990) investigated the distribution of Co-60 in melt experiments performed on beta and gamma contaminated steel scrap. The distribution of cobalt was taken to be an effective indicator for the distribution of iron (Fe-55) and nickel (Ni-59, Ni$63)$.

- In a current RSM decontamination program, Atteridge and others (Atteridge, et al, 1994) state the surrogate choices for cesium and strontium were merely the naturallyoccurring isotopic mixtures of these elements. The naturally-occurring isotopic mixtures of the rare earth elements cerium and neodymium were used because rare earth elements are the most abundant fission products and because these two elements could be used as surrogates for uranium and plutonium, respectively. The choices of $\mathrm{Ce}$ and $\mathrm{Nd}$ as substitutes for all rare earths were reasonable because, in general the reactivities and thermochemical properties of the rare earths are quite similar to one another; lanthanum was chosen as a general surrogate for these same reasons. Atteridge lists the free energies of stable oxides of radionuclides of interest and possible surrogate elements and states the choice of $\mathrm{Ce}$ as a surrogate for actinide elements is a common one.

- The suitability for Ce as a Pu surrogate has recently been discussed by Raraz, Mishra, and Averil. (Raraz, 1993) 
- Worcester, et al (Worcester, 1994) present arguments similar to Atteridge for selection of $\mathrm{Ce}, \mathrm{La}$, and $\mathrm{Nd}$ surrogates and also present arguments for tracking cobalt in experimentation.

- Herbst, et al (Herbst, 1994) selected Hf as a surrogate for $\mathrm{U}$ based on thermodynamic and density considerations in their work on "Quantum-Catalytic" extraction at Molten Metal Technology Corporation.

- In a DOE report, Stockdale, et al (Stockdale, 1994) states the chief radioactive nuclides of concern in the treatment of mixed wastes are ${ }^{239} \mathrm{Pu},{ }^{238} \mathrm{U},{ }^{235} \mathrm{U},{ }^{137} \mathrm{Cs},{ }^{103} \mathrm{Ru}$, ${ }^{99} \mathrm{Tc}$, and ${ }^{90} \mathrm{Sr}$. These nuclides are largely by-products of uranium enrichment, reactor fuel processing, and weapons program activities. ... The seven radionuclides listed can be simulated by a surrogate package containing stable isotopes of ruthenium, strontium, cesium, and cerium.

- Elert, et al (Elert, 1992) have summarized the ten radiologically most important radionuclides present (as a function of time) in decommissioning waste materials; their results are presented in Table 2.2 .

- $\quad$ Dyer and Bechtold (1994) surveyed the types of nuclide contamination present in eleven pressurized boiling reactors (PWRs) and eight boiling water reactors (BWRs). They found that for the PWR reactor coolant, about $90 \%$ of the radionuclide activities are the radiocesium fission products with the other $10 \%$ being iron and cobalt activation products, Fe-55 and $\mathrm{Co}-60$. For the BWR reactor coolant, about $91 \%$ of the activities are from $\mathrm{Sb}-125$ which is an activation product of tin from the condenser tubing. The other $9 \%$ of the BWR reactor coolant activities is mainly from the activation products, Fe-55 and Co-60. For the samples of reactor component parts, between $86 \%$ to as much as $99 \%$ of the radionuclide activities are the activation products, $\mathrm{Fe}-55, \mathrm{Co}-60$, and $\mathrm{Ni}-63$. This distribution of radionuclides for the reactor components appears to be the same whether the activities are contamination on the part surfaces or are contamination distributed within the part materials. In summary, for all the samples reviewed, the radionuclides that provided $1 \%$ or more of the total activities were: Mn- 54 , Fe-55, Co-60, Ni-63, Zn-65, Sb-125, Cs-134, and Cs-137. It appears that these would be the main radionuclides of concern for the recycling of material and stainless steel components from commercial nuclear power reactors in the United States. 
TABLE 2.2. THE TEN RADIOLOGICALLY MOST IMPORTANT RADIONUCLIDES AT DIFFERENT TIMES FOR SURFACE CONTAMINATION FOR DECOMMISSIONING WASTE (Elert, et al, 1992)

\begin{tabular}{|c|c|c||}
\hline$+\mathbf{0}$ Years & $\mathbf{+ 1 0}$ Years & $\mathbf{+ 1 0 0}$ Years \\
\hline Co-60 & Co-60 & Cs-137 \\
\hline Mn-54 & Cs-137 & Sr-90 \\
\hline Co-58 & Sr-90 & Ni-63 \\
\hline Cs-137 & Fe-55 & Co-60 \\
\hline Sr-90 & Ni-63 & Ni-59 \\
\hline Fe-55 & Mn-54 & Am-241 \\
\hline Zn-65 & Cs-134 & Pu-238 \\
\hline Ni-63 & Ni-59 & Pu-240 \\
\hline Cs-134 & Am-241 & Pu-239 \\
\hline Ce-144 & Pu-238 & Cs-135 \\
\hline
\end{tabular}

\subsection{THERMOCHEMISTRY}

During the melt refining of the RSM the metal constituents will react with oxygen to form metallic oxides (oxygen can be supplied from various sources such as flux, air, and other oxides). The metal contaminant species react and form less dense oxides compared to the metal phase constituents and float to the surface to be collected by the slag. Two example reactions between metals and oxygen are illustrated below:

Equation (2.1)

$2 \mathrm{M}+\mathrm{O}_{2}=2 \mathrm{MO}_{2}$

Equation (2.2)

$$
4 / 3 \mathrm{M}+\mathrm{O}_{2}=2 / 3 \mathrm{M}_{2} \mathrm{O}_{3}
$$


The free energy of formation is often used to determine the relative stability of the oxide and metallic species. Free energy. is the driving force for thermodynamic equilibrium; therefore, the direction of a chemical reaction can be determined from the free energy relationship:

$$
\begin{aligned}
& \text { Equation (2.3) } \quad \Delta G=\Delta G^{\circ}+R T \ln (Q) \\
& \text { Equation (2.4) } \quad \Delta \mathrm{G}^{\circ}=-\mathrm{RT} \ln (\mathrm{K}) \text {, where } \\
& \Delta \mathrm{G}^{\circ}=\text { Gibb's Free Energy under standard state conditions } \\
& \mathrm{R}=8.314 \mathrm{~J} / \mathrm{gm} \text { mole } \\
& \mathrm{T}={ }^{\circ} \mathrm{K}
\end{aligned}
$$

Equation (2.5) $\quad Q=a_{\text {products }} / a_{\text {reactants, }}$

where

$$
\begin{aligned}
& a_{\text {products }}=\text { The Product of the Activities of the Product Species } \\
& a_{\text {reactants }}=\text { The Product of the Activities of the Reactant Species }
\end{aligned}
$$

If the free energy is negative the reaction may (depending on the rate of reaction) proceed to the right and form the oxide species, but when the free energy is positive the reaction will not occur.

The basis for melt decontamination of the RSM is the high affinity of oxygen for the surrogate metals compared to the RSM metal constituents. In the presence of an oxidizing species the surrogate elements react first to form oxides before the metal constituents react to form oxides. This process has been described as "...the slag/melt refining program can be visualized graphically by considering the relative thermodynamic stability of the oxide phases for the slag constituents, steel constituents and the surrogate constituents. Relative qualitative stability comparisons are normally made by constructing "Ellingham Diagrams", i.e., plots of free energy of formation of constituent oxides as a function of temperature." (Worcester, et al, 1994)

A simplified visualization can be made using Ellingham diagrams; e.g., the lower the free energy for a specific oxide (i.e., the more negative the free energy of formation) the greater the affinity of the metal for oxygen; therefore, the lowest oxide curve (on a plot of free energy versus temperature) represents the oxide that has the greatest thermodynamic probability of forming. Ellingham diagrams show that the surrogate elements have a greater affinity for oxygen than the steel and stainless steel elements. Ellingham plots for all the major constituents for both steel and stainless steel constituents (including cobalt) are presented in Figure 2.1. Cobalt is included since it is a contaminant in nickel and is a major gamma emitter source. An Ellingham plot is presented in Figure 2.2 for the constituents present in some of the fluxes used in the present study. The surrogate oxide Ellingham plot is presented in Figure 2.3. Note that the free energy curve for cesium oxide lies higher on the plot than the free energy curves for steel and stainless steel constituents. This 
suggests that cesium would not "getter" (form an oxide more stable than the stainless steel constituent oxides). However, cesium has a high volatility and is expected to be eliminated by vaporization from the molten melt. In Figure 2.4 the free energy of formation for the stainless steel oxides is compared to that of lanthanum oxide (representing cerium, lanthanum, and neodymium oxides). Note that lanthanum oxide is more stable than the stainless steel constituent oxides; therefore, lanthanum has a greater affinity for oxygen than do the stainless steel constituents.

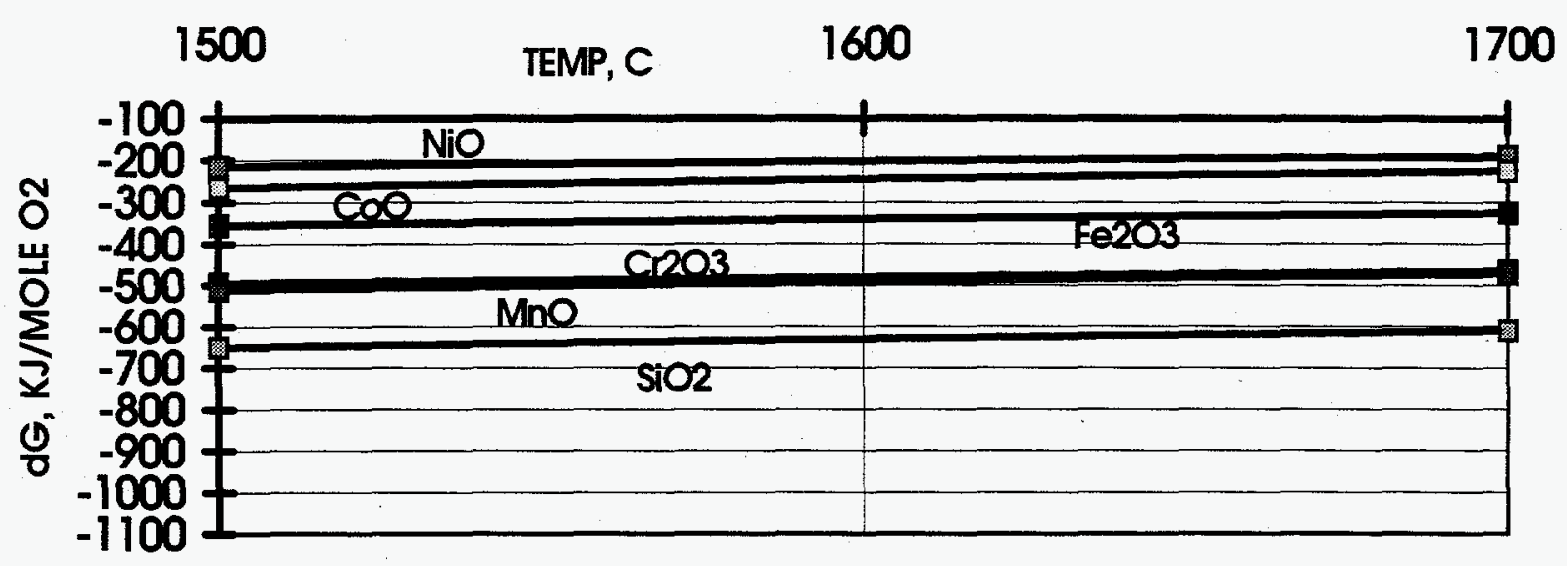

Figure 2.1. Ellingham Diagram for Stainless Steel Constituents (Worcester, et al, 1994)

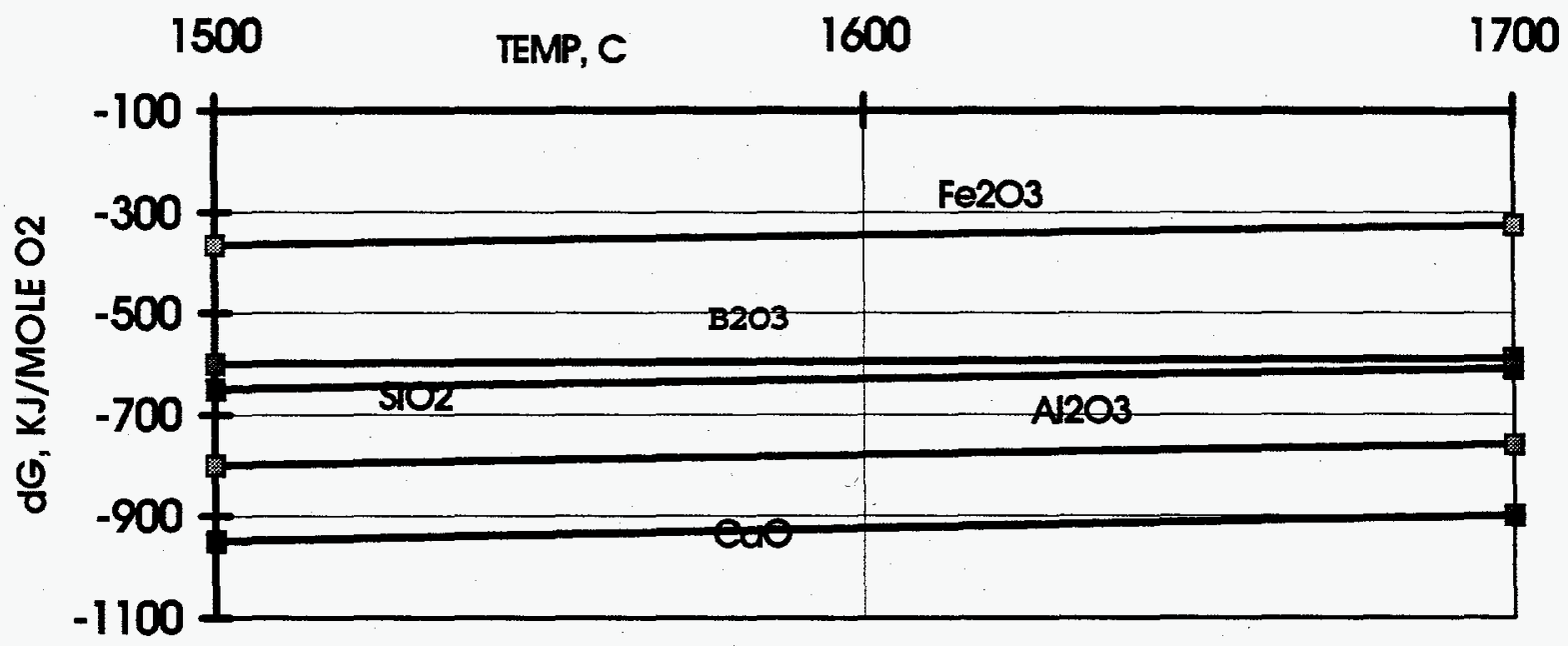

Figure 2.2. Ellingham Diagram for Slag Constituents (Worcester, et al, 1994) 


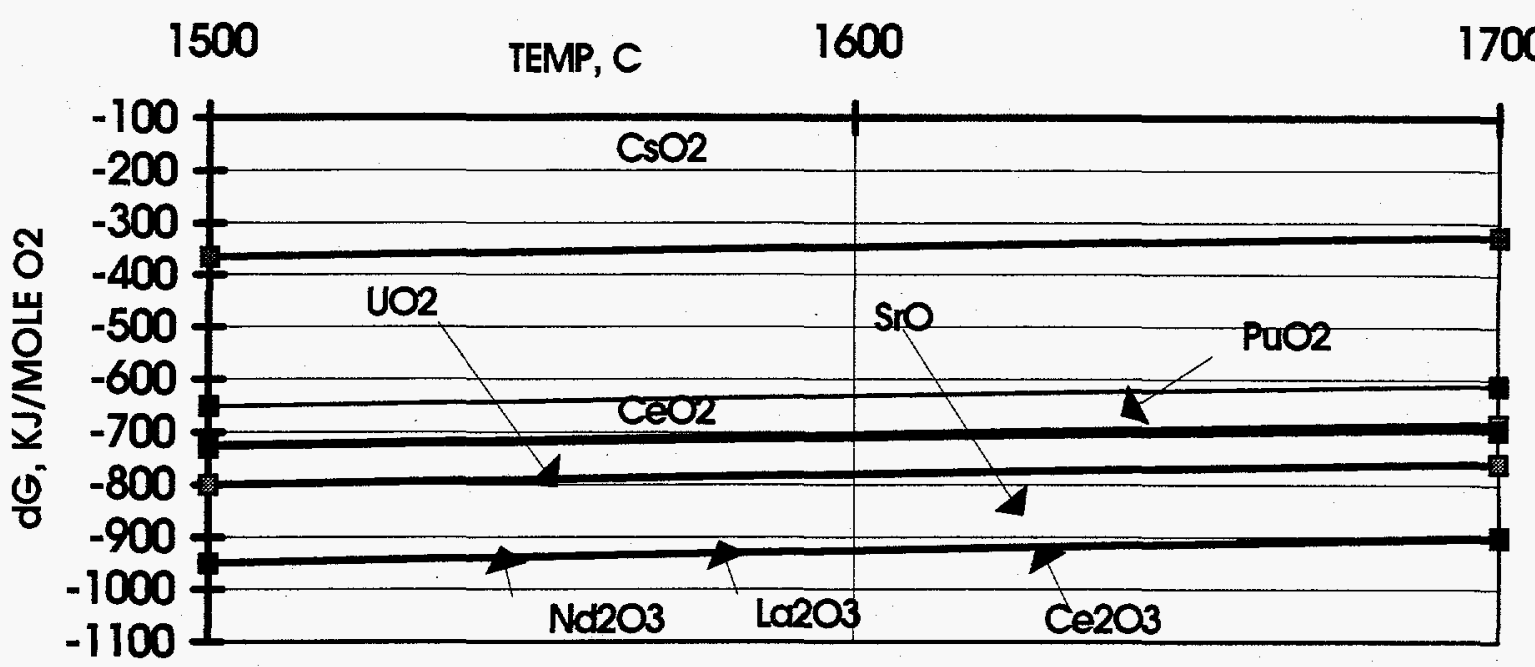

Figure 2.3. Ellingham Diagram for Surrogate Constituents (Worcester, et al, 1994)

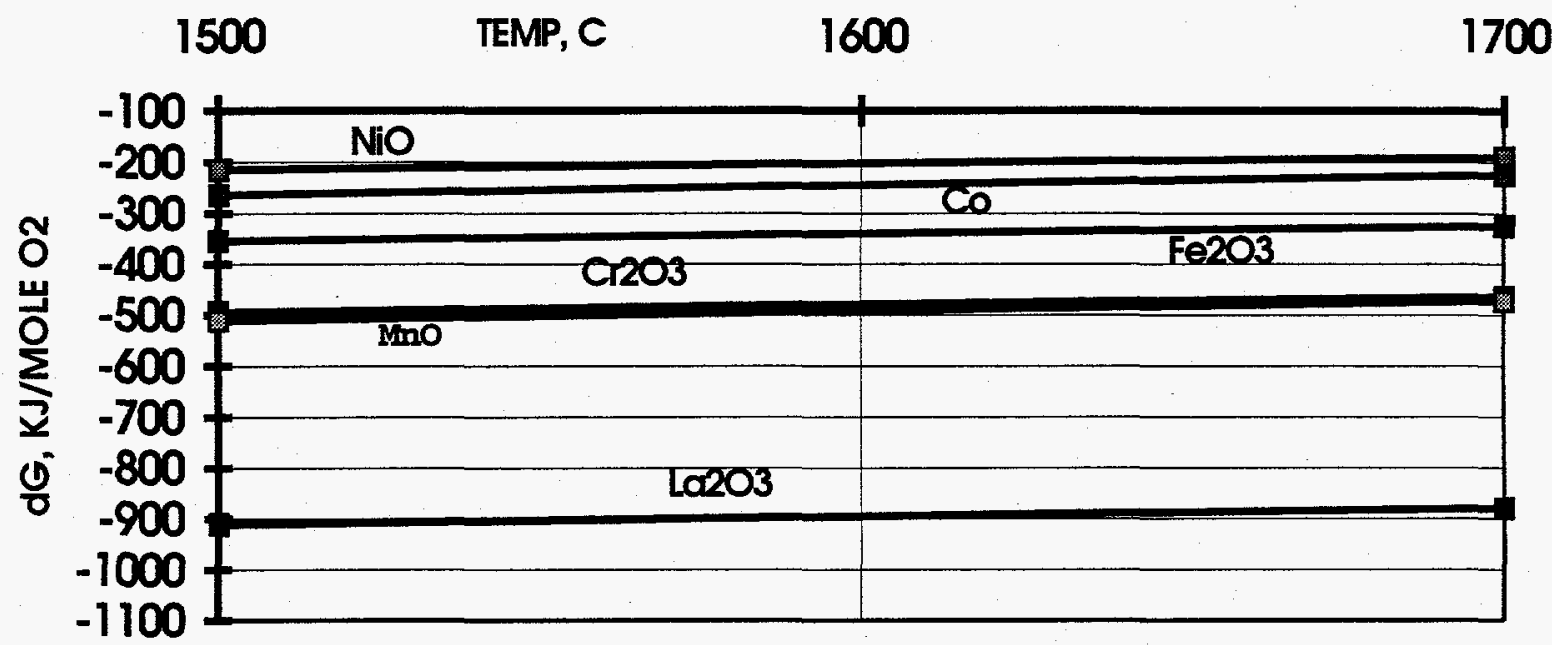

Figure 2.4. Free Energy of Formation for Lanthanum Oxide Compared to Steel Making Constituents (Worcester, et al, 1994) 


\subsection{CALCULATIONAL PROGRAMS}

CSIRO/MONASH, a thermochemistry modeling program (Turnbull, 1992) for calculating high temperature equilibria, has been applied throughout the present study. The CSIRO/MONASH program provides the means for conducting various thermodynamic calculations for checking the thermodynamic feasibility of various proposed experiments. For example, questions similar to the following were considered: are the proposed conditions sufficiently oxidizing for removal of the surrogate elements without removing alloy constituents; will carbon be removed in preference to chromium, silicon, manganese; what is the effect of conducting the experiment in a vacuum; will a significant amount of fume be produced; what is the anticipated effect of raising or lowering the temperature; what is the anticipated effect of changing the flux composition?

There is presently insufficient thermodynamic data available for the surrogate constituents present in either the metal phase or in the slag solution to accurately model the distribution of surrogate elements between the metal, slag and gas phases on an exact quantitative basis. However, qualitative distributions can be determined that can be used as a guide for planning experimental test work. The metal/slag systems investigated in the present study included both stainless steel and carbon steel and a wide variety of slag/gas environments. The activities of the major slag constituents $\left(\mathrm{CaO}, \mathrm{SiO}_{2}\right.$, $\mathrm{Al}_{2} \mathrm{O}_{3}, \mathrm{Fe}_{2} \mathrm{O}_{3}$ ) were assumed to be the same as in a steel refining slag (Elliott and McGleiser, 1963). The activities of the surrogate species in the slag solution $\left(\mathrm{La}_{2} \mathrm{O}_{3}, \mathrm{Nd}_{2} \mathrm{O}_{3}, \mathrm{Ce}_{2} \mathrm{O}_{3}\right)$ were assumed to be ideal, i.e., their activities were taken to the same as their concentrations. The activities of the surrogate species in the steel solution were assumed to be ideal, i.e., their activity coefficients were assumed to be one. The activity coefficients for all the other species in the steel solution were modeled by using the Lupis-Elliott interaction coefficient formulation (Turnbull, 1992).

Examples of what can be learned (on a qualitative basis) from the equilibrium calculations (with comparisons to experimental results) are illustrated below:

- The CSIRO/MONASH calculational program was used to estimate the influence of oxygen on the presence of surrogate elements in stainless steel (under conditions of the plasma preparation of the Master Alloy). A more detailed discussion of this test work is presented in Section 3.4.1 (Master Ingot Preparation). Sufficient surrogate metals (lanthanum, cerium, neodymium) and fluorides (cesium and strontium) were initially added to dope the stainless steel to $1000 \mathrm{mg} / \mathrm{kg}(\mathrm{ppm})$. The results showed that in the presence of only a minor concentration of oxygen ( 0.005 grams oxygen/100 grams stainless steel) that the calculated surrogate concentration in the metal phase was approximately the input amount of surrogate for lanthanum, cerium and neodymium, and zero for cesium and strontium. Also, the calculational results show that just a small amount of oxygen significantly reduces the concentration of the surrogate metals in the stainless steel. This was what was seen in the actual experimental results. The source of oxygen present in the plasma melt environment could be from stainless steel surface oxide deposits or from slight contamination of the inert shrouding gas. The results of the calculation show that only a relatively small amount of oxygen will force the distribution of the rare earth-surrogate elements to the slag phase which 
is in agreement with the experimental results. Experimentally chromium oxide (the most stable oxide of the steel constituent elements) was not detected in the slag phase and the calculational results also show that chromium oxide would not form until a greater amount of oxygen was available than that required for oxidation of the surrogate elements. When the oxygen requirement for the surrogates is satisfied, then chromium will oxidize, e.g., at an oxygen addition of 0.125 gram oxygen $/ 100$ gram stainless steel the chromium content of the slag is estimated (from calculations) to be about four percent, at an oxygen addition of 0.145 gram oxygen/ 100 gram stainless steel the chromium content of the slag is estimated to be about 14 percent, at 0.205 gram oxygen/100 gram steel the slag chromium content is estimated to be 36 percent. (Worcester, et al, 1994)

A second example of the guidance gained by use of the thermodynamic model is in considering what fluxes should be used in the melt/slag experimental test work. Boron oxide addition to high melting flux oxides lowers the melting temperature of the oxide mixture and also increases the fluidity of the slag solution. Therefore, the presence of boron oxide is desirable. However, boron oxide is a relatively volatile oxide and may be lost from the slag phase. This possibility was checked by using the calculational program. The thermodynamic calculational results show that it should be anticipated that the borate content (present in one of the major slag compositions investigated) in the equilibrium slag will be considerably decreased (over the amount added with the input flux) by distribution to the gas phase (as much as $50-60 \%$ may be lost to the gas phase) and (a minor amount) to the stainless steel phase This occurrence will certainly influence the liquidus temperature of the slag. If a strongly oxidizing slag is used then chromium in the stainless steel will oxidize (and will, therefore, be decreased in the metal phase) and the slag liquidus temperature will certainly be raised. Therefore, it was anticipated that there may be a problem in keeping the slag fluid at $1600^{\circ} \mathrm{C}$ if the borate content was decreased (by loss to the gas phase) and/or the chromium oxide content was increased too high (by strongly oxidizing conditions). Both of these effects were noted in our experimental test results, i.e., most of the boron oxide was lost from the slag phase during the test and high chromium contents were noted when strongly oxidizing fluxes were utilized.

- Another example of the usefulness of the calculational program was its use in guiding the experimental test work in the pilot scale vacuum induction melt (VIM) study (calculated results and experimental results are presented in Section 4.1.3). This investigation was aimed specifically at lowering the carbon content to meet the low carbon stainless steel specifications, i.e., $<300 \mathrm{ppm}$, by using vacuum induction melting in the presence of carbon dioxide or magnetite (as the oxygen sources). The calculational and experimental results for anticipated and achieved carbon contents were in general agreement, especially for the magnetite study. 


\title{
DECONTAMINATION AND DECARBURIZATION OF STAINLESS STEEL AND \\ CARBON STEEL BY MELT REFINING
}

\author{
SECTION THREE
}

\section{RESEARCH PROGRAM: \\ LABORATORY SCALE TEST WORK (INDUCTION MELTING)}

\subsection{GOALS OF THE LABORATORY TEST WORK}

The goals of the laboratory test work included:

- The development of a test protocol for induction melt decontamination that results in lowering each surrogate concentration to less than one part per million.

- The determination of the importance of several experimental variables prior to conducting larger demonstration verification tests. The variables investigated included: time, temperature, flux composition, and amount of flux.

\subsection{LITERATURE SEARCH COMMENTS}

Several laboratory scale and large scale melt consolidation programs have been conducted during the past thirty years. Although the major tonnage has been produced by the treatment of mild steel, relatively large scale treatment efforts have also been conducted on stainless steel, nickel, and aluminum. Although the degree of cleanup varied from one program to the other, a large degree of success has been achieved by melt refining for reducing the concentrations of lanthanides, actinides, and most other fission products that are easily oxidized. On the other hand, melt refining to remove troublesome transition elements from stainless steels, such as cobalt and technetium, has met with little success.

Variables that are expected to influence the decontamination efficiency of slagging include: temperature, time, initial contaminant concentration, slag composition, metal composition, and gas environment (oxygen potential). Equilibrium may or may not have been established in the individual slagging studies and the results were likely influenced by variables such as time of exposure, method of addition of radioactive constituents (metals, oxides, hydroxides, halides), initial concentration of radioactive constituents, slag/metal contact (static, dynamic), reaction with crucible materials, slag/metal disengagement technique (slag inclusions formed in the metal phase), and method of sampling final products (surface samples, core samples). None of the published studies reported the final slag composition, i.e., in general, only the composition of the initial flux has been reported. Therefore, because of the many differences in experimental techniques and the lack of complete characterization, the published test work results were reviewed from a phenomenological viewpoint. 
Published laboratory and large scale test work results demonstrate that slagging is an effective decontamination technology for the removal of uranium and plutonium from stainless and mild steel. Based on trends found in the literature, basic calcium-aluminum-silicate slags with additives such as ferric oxide appeared to be effective steel decontaminators and, therefore, the major emphasis in the present laboratory study was placed on using these flux constituents.

\subsection{EXPERIMENTAL TEST FACILITY}

\subsubsection{INDUCTION FURNACE}

The investigators chose induction melting as the best melting method for laboratory scale testing in the scrap metal recycle program. Induction melting was chosen primarily because of the inherent melt stirring. Other advantages of induction melting are high heating rates, easier fume control, easy and fast start-up, and energy savings. Induction heating occurs by two energy loss mechanisms, Joule ( $I^{2} R$ losses) and magnetic hysteresis. When dealing with non-magnetic materials such as austenitic stainless steel, joule heating is the only energy loss mechanism. Joule heating is produced when electrical eddy currents are induced within a conducting material when it is placed in a dynamic magnetic field.

Montana Tech installed and utilized a $15 \mathrm{KW} / 10 \mathrm{KHz}$ induction furnace manufactured by the AJAX Magnethermic Corporation. The furnace consists of two integrated units: first, a water cooled power supply operating on $480 \mathrm{~V}, 3$-phase, $18 \mathrm{KVA}$ power; and second, a table mounted 5-lb furnace connected to the power source through water cooled leads. An adjustable capacitor bank allows the operator to vary operating frequency and current ratios of the power source. Adjustability of the capacitor bank allows maximum furnace control when melting different size melts or when melting different kinds of metals. The power source is controlled by a rheostat dial on the control board when the furnace is operated in manual-control-mode. The operator's panel has direct reading frequency, power, and current meters. Because the furnace has automatic power control, operation learning is minimized and an inexperienced operator can become proficient in several melts. The furnace was operated in manual mode for the present test work, but Montana Tech has installed an automated system which now controls power output by melt temperature via the linear output signal of a two color pyrometer. The automated system digitally records power, current, frequency, time, and temperature during the melt cycle. The table mounted furnace houses a water cooled induction coil and is mechanically supported such that melts are manually poured from the furnace. (Worcester, et al, 1994)

\subsubsection{CRUCIBLE SELECTION AND FABRICATION}

A high alumina-chromium oxide refractory was chosen for fabrication of the furnace crucible used during the initial Montana Tech melt campaign. The refractory was Allied Mineral Products ScottRam Dri-Vibe 437A of composition $\mathrm{Al}_{2} \mathrm{O}_{3} 86.9 \%, \mathrm{Cr}_{2} \mathrm{O}_{3} 7.5 \%, \mathrm{SiO}_{2} 1.7 \%, \mathrm{TiO}_{2} 3.2 \%, \mathrm{Fe}_{2} \mathrm{O}_{3} 0.2 \%$ and others $0.5 \%$, and had a practical temperature limit of $1760^{\circ} \mathrm{C}$. The primary application of the refractory as suggested by the manufacturer is coreless induction melting of stainless steel and other 
high temperature metals. During densification, the refractory's fused alumina base reacts with chromium oxide additive to form a chrome alumina solid solution resistant to slag and metal attack. The solidus of the refractory is approximately $2000^{\circ} \mathrm{C}$.

Overall refractory selection was based on the resistance of the refractory to rapid chemical attack by both the slag and molten metal phases at furnace operating temperatures. The refractory must have adequate mechanical strength to withstand charging of the furnace, and likewise must have adequate thermal shock resistance to withstand the heating and cooling cycles, assuming sequential melting. Also, at the highest anticipated furnace operating temperature, the refractory must not melt which would lead to failure. Reaction products of the refractory/melt interactions should not deleteriously contaminate the melt by decreasing the decontamination potential of the slag. Regardless of refractory selection, some degree of chemical attack will occur at such high operating temperatures in an oxygen deficient melt. Thermodynamically it is predicted that the alumina-chromia refractory will show slight dissolution in the "borate" slag. The stability of the refractory, therefore, depends on the "kinetic" resistance of the crucible to the chosen slag environment. Other refractories that deserve further consideration include: magnesia, chrome magnesite and alumina-magnesia. Because of budgetary and time constraints the only refractory studied in detail was the alumina-chromia material.

Furnace crucibles used in the initial melt campaign were fabricated in a three-step process, where the first two steps involved the ramming of refractory into a green crucible, and the third was the densification process. The water cooled induction coil has a factory installed lining, which is the foundation of the crucible. In the first crucible fabrication stage, StarRam $140\left(\mathrm{Al}_{2} \mathrm{O}_{3} 41.6 \%, \mathrm{CaO}\right.$ $1.08 \%, \mathrm{Fe}_{2} \mathrm{O}_{3} 1.35 \%, \mathrm{MgO} 48.4 \%, \mathrm{SiO}_{2} 7.6 \%$ ) manufactured by American Refractories and Crucible Corporation, was rammed around a mold placed axially in the induction coil. This refractory was used to thermally protect the induction coil while providing mechanical support to the crucible refractory during melting. Following the molding of the StarRam 140, the liner mold was removed and a metallic crucible mold was placed within the liner. Next, Scott-Ram 437A was rammed between the metallic crucible mold and the insulating liner. After the layered ramming was completed, the green crucible was ready for densification.

During densification a stainless steel slug of metal was added to the inner metallic crucible mold. The temperature was slowly increased to $120^{\circ} \mathrm{C}$ and held for two hours and then slowly increased to $1300^{\circ} \mathrm{C}$ at a rate of $210^{\circ} \mathrm{C}$ per hour. After reaching the $1300^{\circ} \mathrm{C}$ temperature, furnace power was increased to melt the stainless steel slug and the metallic mold. The melt was then poured and subsequently discarded. After inspecting the refractory to ensure proper densification, the furnace crucible was deemed ready for melt testing. The entire densification process took a total of nine hours. (Worcester, et al, 1994)

\subsubsection{TEMPERATURE MEASUREMENT}

A Modline R Series Two Color Pyrometer manufactured by IRCON Inc. was installed above the furnace for temperature measurement. The two color pyrometer, also known as a ratio pyrometer, 
is insensitive to varying target material emissivity caused by dynamic target surface conditions or to a partially blocked optical path between the melt and the sensor by melt fumes. The pyrometer measures the intensities of two individual radiation wavelengths, and then computes actual temperature according to the ratio of these intensities. The pyrometer consists of two units: a sensing head, which is mounted directly above the induction table furnace; and an indicator unit, which is mounted to the furnace power supply. Pyrometer measurement range is $900-2,000^{\circ} \mathrm{C}$ and will tolerate a 95 percent reduction in radiation intensity. Temperature is digitally displayed on the indicator display, or can be fed into a controller via a $0-100 \mathrm{mVdc}$ linear output signal for automated furnace control. (Worcester, et al, 1994)

\subsection{MASTER SURROGATE INGOT AND FLUX PREPARATION}

\subsubsection{MASTER INGOT PREPARATION}

\subsubsection{STAINLESS STEEL MASTER INGOT PREPARATION}

Master alloy ingots were prepared to supply the necessary feedstock for all subsequent test work. The master alloy was prepared by melting stainless steel in an inert gas shrouded plasma cold hearth furnace in the presence of surrogate elements $(\mathrm{Ce}, \mathrm{La}, \mathrm{Nd})$ and surrogate fluorides $(\mathrm{Sr}, \mathrm{Cs})$. The preparation of the master alloy was preformed at the RETECH facility in Ukiah, California and the details of the preparation are presented below.

\subsection{PREPARATION OF THE MASTER INGOT}

The feedstock used to produce the master alloy ingots was prepared in the Montana Tech laboratories. The preparation required the fabrication of two 15.2-centimeter feedstock pipes. The feedstock pipes were constructed of 15.2-centimeter schedule-40 304 (in this study Type 304 is used to refer to both Type 304 and 304L) stainless steel pipe. Smaller diameter pipes and flat stock were placed inside the 15.2-centimeter pipes in order to provide the desired total mass. All metal used in the feedstock construction, except for the surrogate elements and weld metal (ER308L), consisted of 304 stainless steel. The final lengths of the two pipe feedstock were 132 and 135 centimeters, with a total weight of 84 and 86 kilograms, respectively.

Three of the surrogate elements (neodymium, cerium, lanthanum) were placed in the feedstock pipe in metal form. The other two surrogate elements (cesium and strontium) were added as cesium fluoride $(\mathrm{CsF})$ and strontium fluoride $\left(\mathrm{SrF}_{2}\right)$. The surrogate metals were encapsulated in argon in 3.2-centimeter stainless steel tubes, i.e., "packets." Sufficient surrogate elements were included to provide a final concentration in the steel product of 0.1 weight percent $(1000 \mathrm{ppm})$. Packets were fabricated in a glove box containing an inert argon atmosphere. To achieve a relatively homogeneous ingot, individual "packets" were welded along the length of the two pipes at $9.1-\mathrm{Kg}$ equivalent intervals. The packet/pipe construction was then slid into the 15.2-centimeter feedstock pipe. Photographs of the assembling process are presented in Figures 3.1.-3.3 


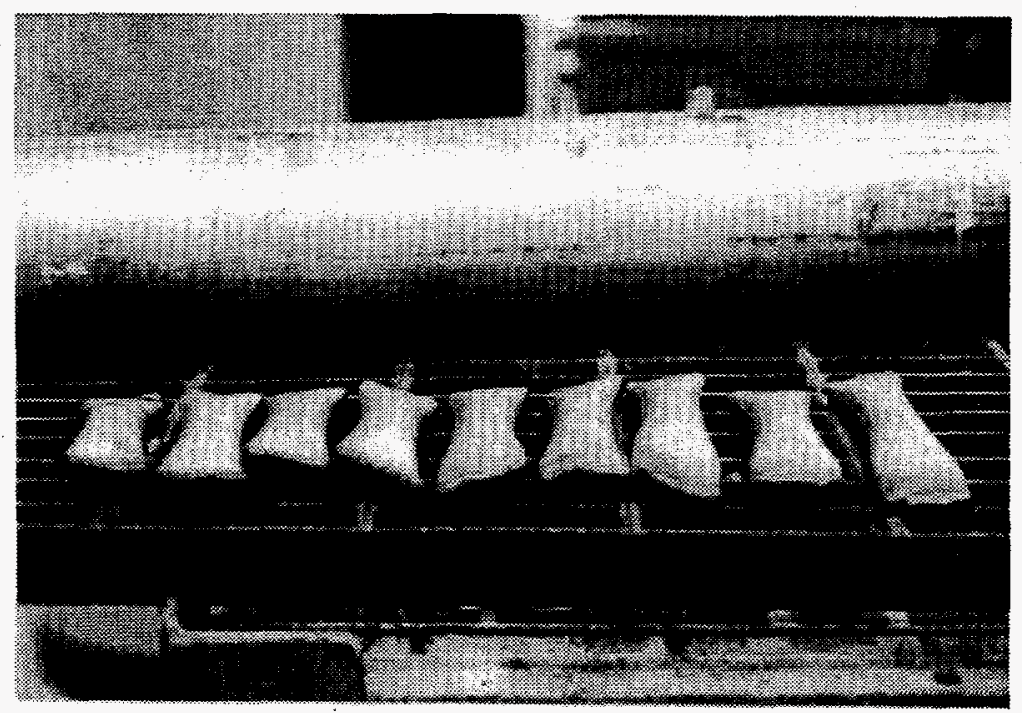

Figure 3.1. Photograph of the Pilot-Scale Feedstock Preparation Sequence: Welded Surrogate Package

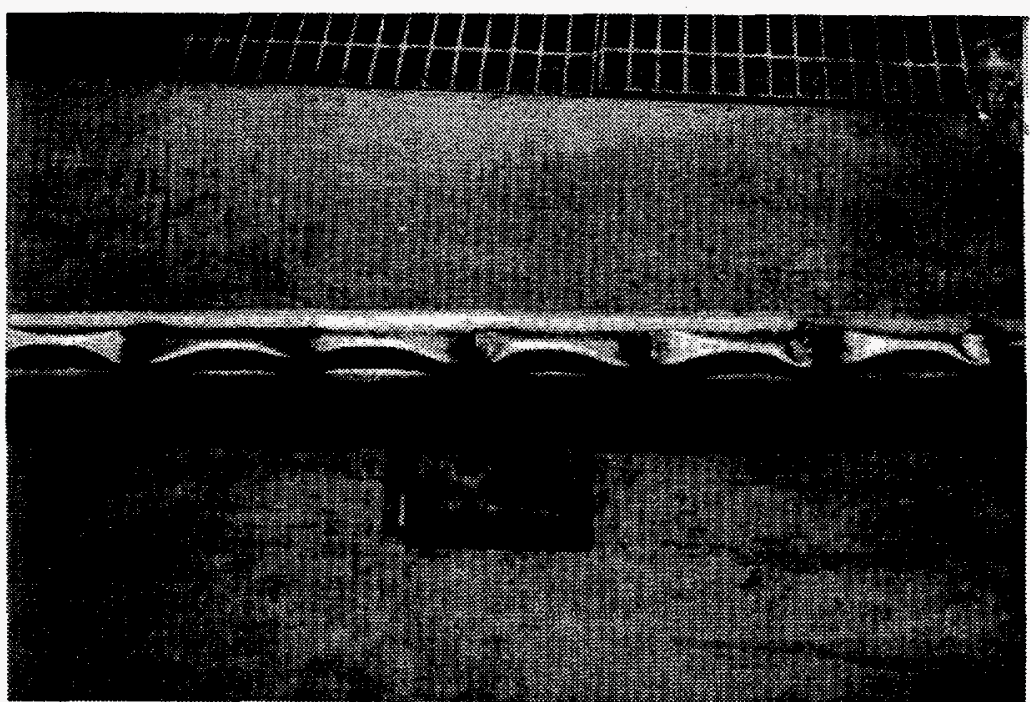

Figure 3.2. Photograph of the Pilot-Scale Feedstock Preparation Sequence: Surrogate Packages Welded to Insert Pipes 


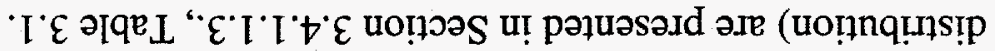

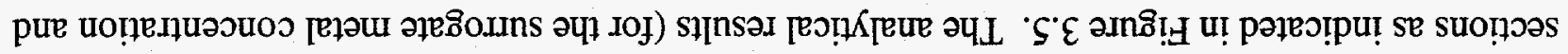

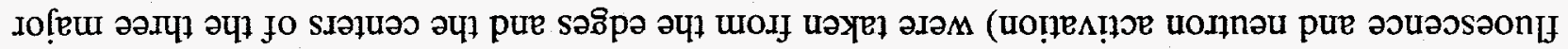

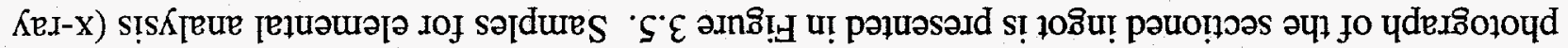
$\forall{ }^{\prime}{ }^{\prime} \varepsilon$ ว

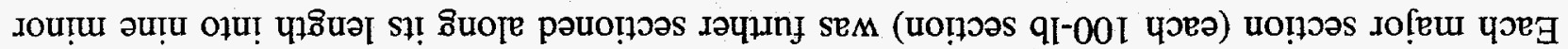

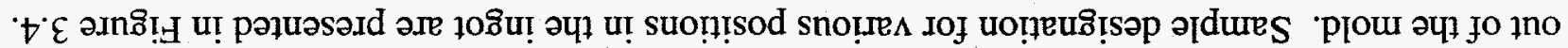

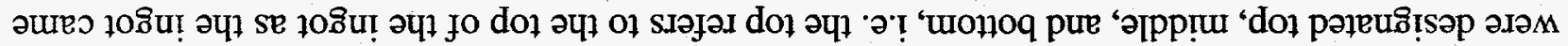

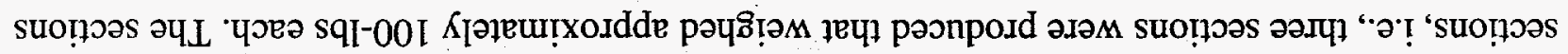

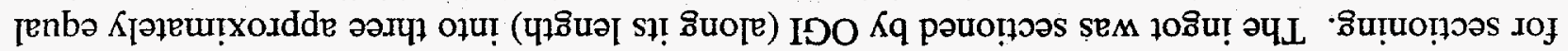

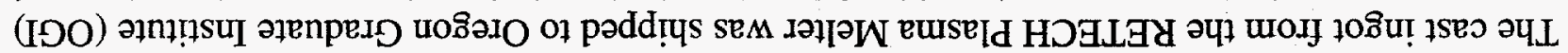

\section{LODNI YGLSVIN GH.L HO SIS TVNV INV DNITdWVS 'DNINOILOHS}

\section{$\boldsymbol{r}^{*} \boldsymbol{I}^{\cdot} \mathbf{I}^{*} \boldsymbol{t}^{*} \mathcal{\varepsilon}$}

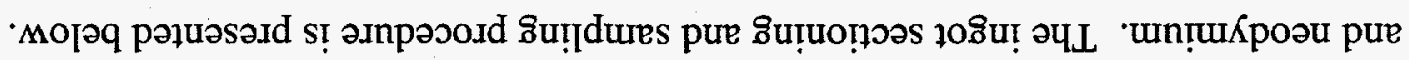

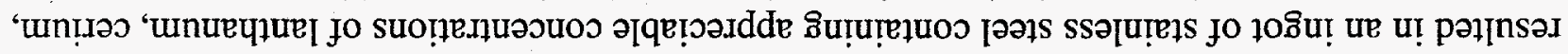

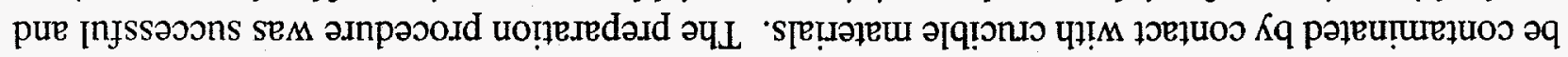

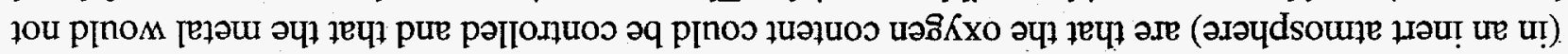

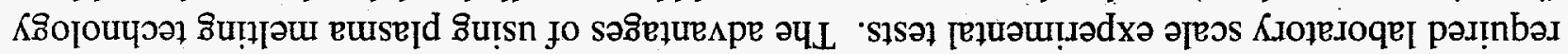

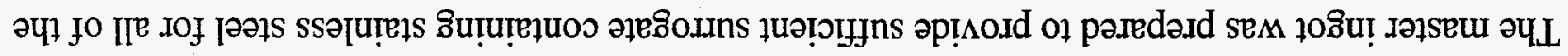

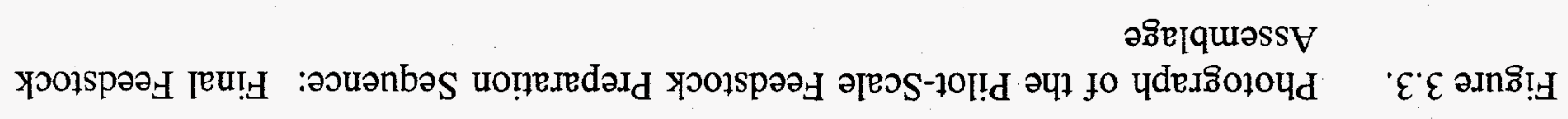

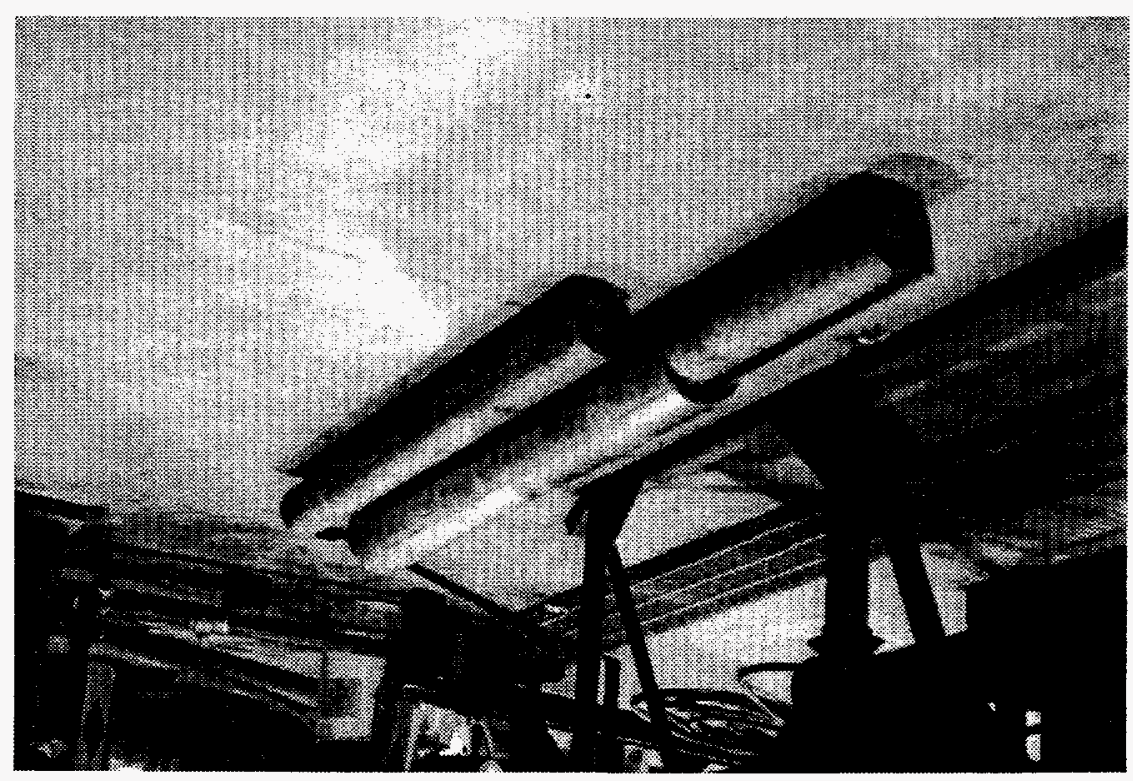



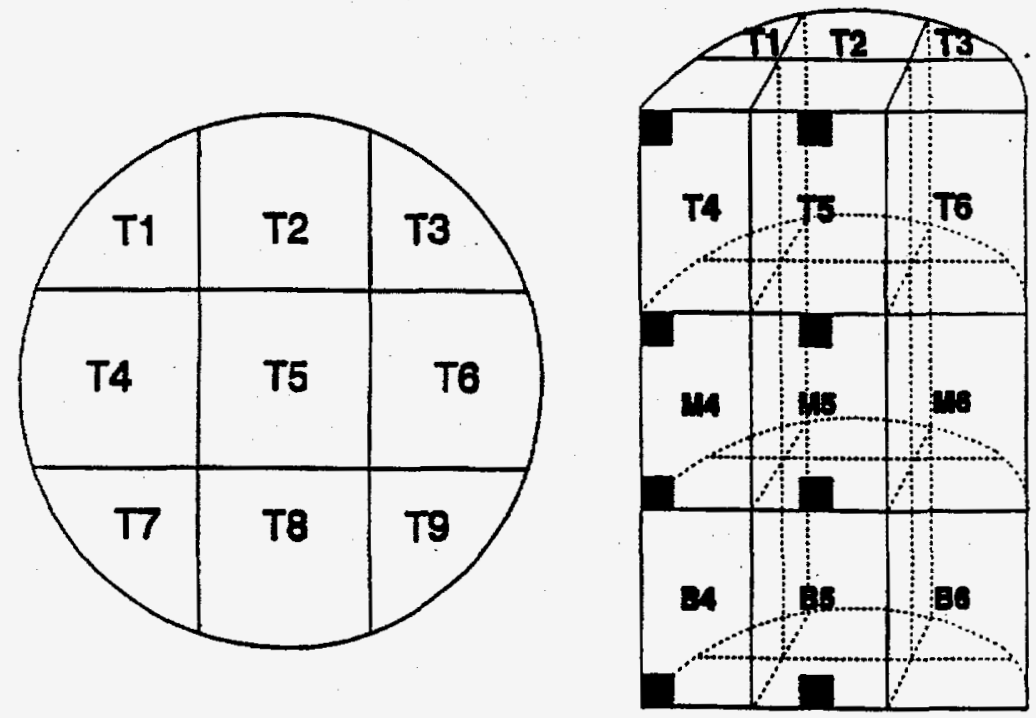

Figure 3.4. Schematic Diagram Depicting the Numbering Sequence Designation and Elemental Analysis Location of samples from the Master Ingot

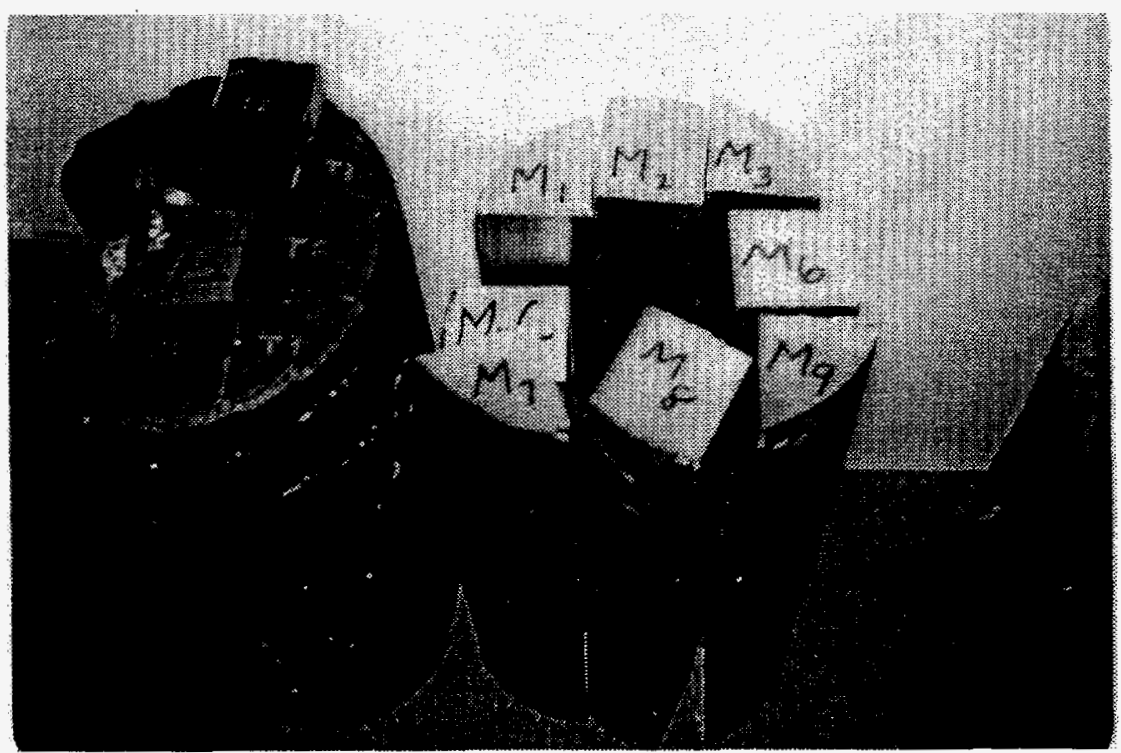

Figure 3.5. Photograph of the Sectioned Master Ingot 


\subsection{MASTER INGOT COMPOSITION AND DISCUSSION}
TABLE 3.1. SURROGATE COMPOSITION OF THE STAINLESS STEEL MASTER INGOT (Worcester, et al, 1994)

\begin{tabular}{|c|c|c|c|c|c|}
\hline \multirow{2}{*}{$\begin{array}{c}\text { SAMPLE } \\
\text { (NUMBERING } \\
\text { PER FIGURE } \\
\text { 3.5) }\end{array}$} & \multicolumn{5}{|c|}{ SURROGATE ELEMENTS AND CONCENTRATIONS } \\
\hline & CS, PPM & SR, PPM & CE, PPM & LA, PPM & ND, PPM \\
\hline $\mathrm{T}_{4} \mathrm{E}^{(1)}$ & 96 & $<$ D.L. ${ }^{(5)}$ & 479 & 352 & 851 \\
\hline $\mathrm{M}_{4} \mathrm{EA}^{(1)}$ & $<$ D.L. & $<$ D.L. & 680 & 499 & 577 \\
\hline$M 4 E B^{(1)}$ & $<$ D.L. & $<$ D.L: & 330 & 500 & 420 \\
\hline $\operatorname{MSCA}^{(1)}$ & $<$ D.L. & $<$ D.L. & 749 & 435 & 826 \\
\hline M5CA $^{(2)}$ & $<3.9$ & $<2300$ & 719 & 376 & 498 \\
\hline $\mathrm{M} \mathrm{CB}^{(1)}$ & $<$ D.L. & $<$ D.L. & 428 & 504 & 740 \\
\hline $\mathrm{M}_{5 \mathrm{CB}^{(2)}}$ & $<3.9$ & $<1900$ & 507 & 343 & 416 \\
\hline $\mathrm{T} \mathrm{CA}^{(1)}$ & $<$ D.L. & $<$ D.L. & 490 & 330 & 620 \\
\hline $\mathrm{T} \mathrm{CA}^{(2)}$ & $<6.0$ & $<2300$ & 525 & 272 & 332 \\
\hline $\mathrm{T}^{5} \mathrm{CA}^{(3)}$ & 0.88 & 2.3 & 510 & 300 & 450 \\
\hline $\mathrm{B} \mathrm{MB}^{(1)}$ & $<$ D.L. & $<$ D.L. & 560 & 470 & 660 \\
\hline${\mathrm{B} 5 \mathrm{MB}^{(2)}}^{(2)}$ & $<4.8$ & $<2400$ & 770 & 417 & 546 \\
\hline B4EB ${ }^{(1)}$ & $<$ D.L. & $<$ D.L. & 460 & 370 & 570 \\
\hline Average $^{(4)}$ & & & $522 \pm 136$ & $432 \pm 72$ & $658 \pm 144$ \\
\hline \multicolumn{6}{|c|}{$\begin{array}{l}1 \text { Analysis results are from X-ray fluorescence Analysis, Ashe Analytics. } \\
2 \text { Analysis results are from Instrumental Neutron Activation Analysis, } \\
\text { Oregon State University Radiation Center. } \\
3 \text { Analysis results are from ICP-Mass Spec, Teledyne Wah Chang Albany. } \\
4 \text { Averaged values are only for X-ray fluorescence analysis results. } \\
5 \text { D.L.=Detection Limit }\end{array}$} \\
\hline
\end{tabular}

The CSIRO/MONASH calculational program (Turnbull, 1992) was used to estimate the influence of oxygen on the presence of surrogate elements in stainless steel (under conditions of the RETECH furnace operation). Sufficient surrogate metals (lanthanum, cerium, neodymium) and fluorides (cesium and strontium) were initially added to dope the stainless steel to $1000 \mathrm{mg} / \mathrm{kg} \mathrm{(ppm).} \mathrm{It} \mathrm{was}$ assumed in the calculation program that all slag constituent activity coefficients were one; the temperature was $1600^{\circ} \mathrm{C}$; and that the oxygen input per 100 grams of stainless steel was varied. The 
analytical and calculational results are presented for the metal phase in Table 3.2. and for the slag phase in Table 3.3. Note (in Table 3.2) that in the presence of only a minor concentration of oxygen (0.005 grams oxygen/100 grams stainless steel) that the calculated surrogate concentration in the metal phase is approximately the input amount of surrogate for lanthanum, cerium and neodymium, and zero for cesium (lost to the gas phase because of its relatively high volatility at elevated temperatures) and strontium (lost to the slag phase as strontium fluoride). Note also that a small additional amount of oxygen significantly reduces the concentration of the surrogate metals in the stainless steel. The source of oxygen present in the plasma melt environment could be from the stainless steel surface or from slight contamination of the inert shrouding gas. The results of the calculation do show that only a relatively small amount of oxygen will force the distribution of the rare earth-surrogate elements to the slag phase (Table 3.3).

TABLE 3.2. PREPARATION OF STAINLESS STEEL MASTER INGOT: METAL PHASE

\begin{tabular}{|c|c|c|c|c|c|c|c|c|c|}
\hline \multirow{3}{*}{ ELEMENT } & \multicolumn{2}{|c|}{$\begin{array}{c}\text { MEASURED, PPM IN } \\
\text { METAL }\end{array}$} & \multicolumn{7}{|c|}{ CALCULATED $^{(3)}$, PPM IN METAL } \\
\hline & \multirow[t]{2}{*}{ SKULL ${ }^{(1)}$} & \multirow[t]{2}{*}{ INGOT $^{(2)}$} & \multicolumn{7}{|c|}{ GRAMS OXYGEN PRESENT/100 GRAMS OF STAINLESS STEEL } \\
\hline & & & 0.005 & 0.025 & 0.045 & 0.065 & 0.085 & 0.105 & 0.125 \\
\hline Cs & $<\mathrm{DL}$ & $\leq \mathrm{DL}$ & $<0.0$ & $<0.0$ & $<0.0$ & $<0.0$ & $<0.0$ & $<0.0$ & $<0.0$ \\
\hline $\mathrm{Sr}$ & $<\mathrm{DL}$ & $\leq \mathrm{DL}$ & $<0.0$ & $<0.0$ & $<0.0$ & $<0.0$ & $<0.0$ & $<0.0$ & $<0.0$ \\
\hline $\mathrm{Ce}$ & $530 \pm 60$ & $352 \pm 11$ & 1018 & 517 & 160 & 9 & 1 & $<1$ & $<0.0$ \\
\hline $\mathrm{La}$ & $140 \pm 80$ & $448 \pm 45$ & 1018 & 534 & 199 & 12 & 2 & $<1$ & $<0.0$ \\
\hline $\mathrm{Nd}$ & $357 \pm 100$ & $630 \pm 32$ & 1016 & 513 & 159 & 9 & 1 & $\leq 1$ & $<0.0$ \\
\hline 1 & \multirow{3}{*}{\multicolumn{9}{|c|}{$\begin{array}{l}\text { Skull sample analyzed by x-ray fluorescence, Ashe Analytics. The skull metal may not be representative of the } \\
\text { master ingot. } \\
\text { Master ingot samples analyzed by neutron activation, Oregon State University. } \\
\text { CSIRO/MONASH program. Assumptions include: activity coefficients for all slag constituents assumed to be } \\
\text { one. All surrogate constituent activity coefficients in the metal were assumed to be one. Other metal constituent } \\
\text { activity coefficients in the metal were estimated by using the Lupis-Elliott interaction coefficient model. }\end{array}$}} \\
\hline 2 & & & & & & & & & \\
\hline 3 & & & & & & & & & \\
\hline
\end{tabular}

One of the questions of concern for subsequent melt/slag contact experiments was whether the surrogates would "getter" the oxygen from the available oxygen sources (the gas or slag atmosphere) in preference to the steel constituents. The master ingot preparation test results and the CSIRO/MONASH program calculational results have both demonstrated that the rare-earth surrogates were, indeed, distributed to the slag phase in preference to the steel component constituents (such as iron, chromium and nickel). Chromium oxide (the most stable oxide of the steel constituent elements) was not detected in the slag phase and the calculational results also show that chromium oxide would not form until a greater amount of oxygen was available than that required for oxidation of the surrogate elements. When the oxygen requirement for the surrogates is satisfied, then chromium oxidizes, e.g., at an oxygen addition of 0.125 gram oxygen 100 gram 
stainless steel the chromium content of the slag is estimated to be about four percent, at an oxygen addition of 0.145 gram oxygen $/ 100$ gram stainless steel the chromium content of the slag is estimated to be about 14 percent, at 0.205 gram oxygen/100 gram steel the slag chromium content is estimated to be 36 percent. (Worcester, et al, 1994)

TABLE 3.3. PREPARATION OF STAINLESS STEEL MASTER INGOT: SLAG PHASE

\begin{tabular}{|c|c|c|c|c|c|c|c|}
\hline \multirow[t]{3}{*}{ ELEMENT } & \multicolumn{2}{|c|}{$\begin{array}{c}\text { MEASURED, \% IN } \\
\text { SLAG }^{(1)}\end{array}$} & \multicolumn{5}{|c|}{ CALCULATED, \% OXIDES IN SLAG ${ }^{(2)}$} \\
\hline & \multirow[t]{2}{*}{$\begin{array}{c}\text { AS } \\
\text { METALS }\end{array}$} & \multirow[t]{2}{*}{$\begin{array}{c}\text { AS } \\
\text { OXIDES }\end{array}$} & \multicolumn{5}{|c|}{$\begin{array}{l}\text { GRAMS OXYGEN PRESENT/100 GRAMS OF } \\
\text { STANLESS STEEL }\end{array}$} \\
\hline & & & 0.025 & 0.045 & 0.065 & 0.085 & 0.105 \\
\hline Cs & 0.027 & $\begin{array}{c}0.02 \text { as } \\
\mathrm{CaF}\end{array}$ & $<0.0$ & $<0.0$ & $<0.0$ & $<0.0$ & $<0.0$ \\
\hline $\mathbf{S r}$ & 28.4 & $\begin{array}{c}23.9 \text { as } \\
\mathrm{SrF}_{2} \\
\end{array}$ & $\begin{array}{c}18.6 \text { as } \\
\mathrm{SrF}_{2}\end{array}$ & $\begin{array}{c}15.3 \text { as } \\
\mathrm{SrF}_{2} \\
\end{array}$ & $\begin{array}{c}14.2 \text { as } \\
\mathrm{SrF}_{2} \\
\end{array}$ & $\begin{array}{c}14.2 \text { as } \\
\mathrm{SrF}_{2} \\
\end{array}$ & $\begin{array}{c}14.2 \text { as } \\
\mathrm{SrF}_{2} \\
\end{array}$ \\
\hline $\mathrm{Ce}$ & 9.1 & 12.5 & 28.7 & 28.7 & 28.7 & 28.7 & 28.7 \\
\hline $\mathbf{L a}$ & 18.9 & 26.0 & 24.0 & 27.4 & 28.7 & 28.7 & 28.7 \\
\hline Nd & 15.3 & 21.0 & 28.8 & 28.6 & 28.7 & 28.5 & 28.7 \\
\hline \multicolumn{8}{|c|}{$\begin{array}{l}1 \text { Slag chipped from skull metal. Analyzed by Ashe Analytics. } \\
2 \text { CSIRO/MONASH program. Assumptions include: activity coefficients for all slag constituents assumed to } \\
\text { be one. All surrogate constituent activity coefficients in the metal were assumed to be one. Other metal } \\
\text { constituent activity coefficients in the metal were estimated by using the Lupis-Elliott interaction coefficient } \\
\text { model. }\end{array}$} \\
\hline
\end{tabular}

\subsubsection{CARBON STEEL MASTER INGOT}

A carbon steel master ingot was also assembled and plasma melted in a manner similar to the preparation of the stainless steel ingot. To facilitate obtaining feedstock for the small induction furnace, the 15.2-centimeter master ingot was forged (at Schlosser Forge) to a 4.4-cm round which was then sectioned for feed to the small induction furnace. Analytical results and surrogate predictions for the steel master ingot are presented in Table 3.4 
TABLE 3.4. PREPARATION OF STEEL MASTER INGOT: METAL PHASE

\begin{tabular}{|c|c|c|c|c|c|c|c|c|c|}
\hline \multirow{3}{*}{ ELEMENT } & \multicolumn{2}{|c|}{$\begin{array}{l}\text { MEASURED, PPM IN } \\
\text { METAL }\end{array}$} & \multicolumn{7}{|c|}{ CALCULATED $^{(1)}$, PPM IN METAL } \\
\hline & \multirow[t]{2}{*}{ MSM1 } & \multirow[t]{2}{*}{ MSM2 } & \multicolumn{7}{|c|}{ GRAMS OXYGEN PRESENT/100 GRAMS OF STEEL } \\
\hline & & & 0.005 & 0.025 & 0.045 & 0.065 & 0.085 & 0.105 & 0.125 \\
\hline Cs & $<\mathrm{DL}$ & $\angle D L$ & 1.2 & 1.2 & 1.2 & 1.1 & 1.0 & $<1.0$ & $<1.0$ \\
\hline $\mathrm{Sr}$ & 2 & $<\mathrm{DL}$ & 10.1 & 9.4 & 7.8 & 5.9 & 3.7 & 1.3 & $<1.0$ \\
\hline $\mathrm{Ce}$ & 170 & 230 & 676 & 436 & 188 & 60 & 14 & 1.0 & $<1.0$ \\
\hline $\mathrm{La}$ & 130 & 96 & 490 & 360 & 176 & 60 & 14 & $<1.0$ & $<1.0$ \\
\hline $\mathrm{Nd}$ & 170 & 240 & 776 & 478 & 200 & 62 & 14 & $<1.0$ & $<1.0$ \\
\hline
\end{tabular}

Calculated slag compositions for the carbon steel surrogate melt are included in Table 3.5. No analyses were performed on the slag phase obtained from the carbon steel master preparation surrogate melt.

TABLE 3.5. PREPARATION OF STEEL MASTER INGOT: SLAG PHASE

\begin{tabular}{|c|c|c|c|c|c|c|c|c|c|}
\hline \multirow{3}{*}{ ELEMENT } & \multicolumn{2}{|c|}{$\begin{array}{l}\text { MEASURED, \% IN } \\
\text { SLAG }\end{array}$} & \multicolumn{7}{|c|}{ CALCULATED, \% OXIDES IN SLAG ${ }^{(1)}$} \\
\hline & \multirow{2}{*}{$\begin{array}{c}\text { AS } \\
\text { METALS }\end{array}$} & \multirow{2}{*}{$\underset{\text { OXIDES }}{\text { AS }}$} & \multicolumn{7}{|c|}{ GRAMS OXYGEN PRESENT/100 GRAMS OF STEEL } \\
\hline & & & 0.005 & 0.025 & 0.045 & 0.065 & 0.085 & 0.105 & 0.125 \\
\hline Cs & N.A. & N.A. & $<0.01$ & $<0.01$ & $<0.01$ & $<0.01$ & $<0.01$ & $<0.01$ & $<0.01$ \\
\hline $\mathrm{Sr}$ & N.A. & N.A. & $\begin{array}{c}0.02 \text { as } \\
\mathrm{SrO} \\
2.7 \text { as } \\
\mathrm{SrF}_{2} \\
\end{array}$ & $\begin{array}{c}0.04 \text { as } \\
\mathrm{SrO} \\
2.5 \text { as } \mathrm{SrF}_{2}\end{array}$ & $\begin{array}{l}0.12 \text { as } \\
\mathrm{SrO} \\
4.2 \text { as } \\
\mathrm{SrF}_{2} \\
\end{array}$ & $\begin{array}{c}0.26 \text { as } \\
\mathrm{SrO} \\
6.3 \text { as } \\
\mathrm{SrF}_{2} \\
\end{array}$ & $\begin{array}{c}0.42 \text { as } \\
\mathrm{SrO} \\
8.2 \text { as } \\
\mathrm{SrF}_{2} \\
\end{array}$ & $\begin{array}{c}0.74 \text { as } \\
\mathrm{SrO} \\
10.4 \text { as } \\
\mathrm{SrF}_{3} \\
\end{array}$ & $\begin{array}{c}1.8 \text { as } \\
\mathrm{SrO} \\
13.1 \text { as } \\
\mathrm{SrF}_{2} \\
\end{array}$ \\
\hline $\mathrm{Ce}$ & N.A. & N.A. & $\begin{array}{c}7.6 \text { as } \\
\mathrm{Ce}_{2} \mathrm{O}_{3} \\
10.5 \text { as } \\
\mathrm{CeF}_{3} \\
\end{array}$ & $\begin{array}{c}24.0 \text { as } \\
\mathrm{Ce}_{2} \mathrm{O}_{3} \\
4.3 \text { as } \\
\mathrm{CeF}_{3} \\
\end{array}$ & $\begin{array}{l}28.8 \text { as } \\
\mathrm{Ce}_{2} \mathrm{O}_{3} \\
1.6 \text { as } \\
\mathrm{CeF}_{3} \\
\end{array}$ & $\begin{array}{c}29.0 \text { as } \\
\mathrm{Ce}_{2} \mathrm{O}_{3} \\
0.99 \text { as } \\
\mathrm{CeF}_{3}\end{array}$ & $\begin{array}{c}28.9 \text { as } \\
\mathrm{Ce}_{2} \mathrm{O}_{3} \\
0.69 \text { as } \\
\mathrm{CeF}_{3} \\
\end{array}$ & $\begin{array}{c}28.5 \text { as } \\
\mathrm{Ce}_{2} \mathrm{O}_{3} \\
0.43 \text { as } \\
\mathrm{CeF}_{3}\end{array}$ & $\begin{array}{c}26.7 \text { as } \\
\mathrm{Ce}_{2} \mathrm{O}_{3} \\
0.17 \text { as } \\
\mathrm{CeF}_{3}\end{array}$ \\
\hline $\mathrm{La}$ & N.A. & N.A. & $\begin{array}{c}0.24 \text { as } \\
\mathrm{La}_{2} \mathrm{O}_{3} \\
68.7 \text { as } \\
\mathrm{LaF}_{3}\end{array}$ & $\begin{array}{c}1.6 \text { as } \\
\mathrm{La}_{2} \mathrm{O}_{3} \\
40.2 \text { as } \\
\mathrm{LaF}_{3}\end{array}$ & $\begin{array}{c}6.5 \text { as } \\
\mathrm{La}_{2} \mathrm{O}_{3} \\
28.7 \text { as } \\
\mathrm{LaF}_{1}\end{array}$ & $\begin{array}{c}11.0 \text { as } \\
\mathrm{La}_{2} \mathrm{O}_{3} \\
22.6 \text { as } \\
\mathrm{LaF}_{3}\end{array}$ & $\begin{array}{c}14.3 \text { as } \\
\mathrm{La}_{2} \mathrm{O}_{3} \\
18.2 \text { as } \\
\mathrm{LaF}_{3}\end{array}$ & $\begin{array}{c}18.2 \text { as } \\
\mathrm{La}_{2} \mathrm{O}_{3} \\
12.7 \text { as } \\
\mathrm{LaF}_{3}\end{array}$ & $\begin{array}{c}22.2 \text { as } \\
\mathrm{La}_{2} \mathrm{O}_{3} \\
5.6 \text { as } \\
\mathrm{LaF}_{3}\end{array}$ \\
\hline
\end{tabular}




\begin{tabular}{|c|c|c|c|c|c|c|c|c|c|}
\hline \multirow{3}{*}{ ELEMENT } & \multicolumn{2}{|c|}{$\begin{array}{c}\text { MEASURED, \% IN } \\
\text { SLAG }\end{array}$} & \multicolumn{7}{|c|}{ CALCULATED, $\%$ OXIDES IN SLAG ${ }^{(1)}$} \\
\hline & \multirow{2}{*}{$\begin{array}{c}\text { AS } \\
\text { METALS }\end{array}$} & \multirow{2}{*}{$\underset{\text { OXIDES }}{\text { AS }}$} & \multicolumn{7}{|c|}{ GRAMS OXYGEN PRESENT/100 GRAMS OF STEEL } \\
\hline & & & 0.005 & 0.025 & 0.045 & 0.065 & 0.085 & 0.105 & 0.125 \\
\hline Nd & N.A. & N.A. & $\begin{array}{l}10.2 \text { as } \\
\mathrm{Nd}_{2} \mathrm{O}_{3} \\
0.06 \text { as } \\
\mathrm{NdF}_{3}\end{array}$ & $\begin{array}{c}27.3 \text { as } \\
\mathrm{Nd}_{2} \mathrm{O}_{3} \\
0.02 \text { as } \\
\mathrm{NdF}_{3}\end{array}$ & $\begin{array}{c}30.1 \text { as } \\
\mathrm{Nd}_{2} \mathrm{O}_{3} \\
<0.01 \\
\text { as } \mathrm{NdF}_{3}\end{array}$ & $\begin{array}{c}29.8 \text { as } \\
\mathrm{Nd}_{2} \mathrm{O}_{3} \\
<0.01 \text { as } \\
\mathrm{NdF}_{3}\end{array}$ & $\begin{array}{l}29.4 \text { as } \\
\mathrm{Nd}_{2} \mathrm{O}_{3} \\
<0.01 \\
\text { as } \mathrm{NdF}_{3}\end{array}$ & $\begin{array}{l}28.8 \text { as } \\
\mathrm{Nd}_{2} \mathrm{O}_{3} \\
<0.01 \\
\text { as } \\
\mathrm{NdF}_{3}\end{array}$ & $\begin{array}{l}26.7 \text { as } \\
\mathrm{Nd}_{2} \mathrm{O}_{3} \\
<0.01 \\
\quad \text { as } \\
\mathrm{NdF}_{3}\end{array}$ \\
\hline \multicolumn{10}{|c|}{$\begin{array}{l}1 \text { CSIRO/MONASH program. Assumptions include: activity coefficients for all slag constituents assumed to be one. All surrogate } \\
\text { constituent activity coefficients in the metal were assumed to be one. Other metal constituent activity coefficients in the metal were } \\
\text { estimated by using the Lupis-Elliott interaction coefficient model. } \\
\text { N.A.=Not Analyzed }\end{array}$} \\
\hline
\end{tabular}

\subsubsection{FLUX PREPARATION}

Flux constituents used in the laboratory scale test work included $\mathrm{CaO}, \mathrm{Al}_{2} \mathrm{O}_{3}, \mathrm{SiO}_{2}, \mathrm{Fe}_{2} \mathrm{O}_{3}$, $\mathrm{CaSiO}_{3}, \mathrm{Ca}\left(\mathrm{BO}_{3}\right)_{2}$, and $\mathrm{CaF}_{2}$. Each desired flux formulation (each formulation tested is presented in Section 3.5) was made by adding the appropriate amounts of each constituent. Powdered flux constituents were weighed and combined into a mixing bottle and then rolled for fifteen minutes to ensure that the constituents were homogeneously distributed. After mixing, the flux was poured around the metal charge prior to melting.

\subsection{MELT/SLAG REFINING PROCEDURE}

The master stainless steel ingots were sectioned as shown in the ingot map, Figure 3.5 . After the master ingot was sectioned, pieces ranging from 680 to 1360 grams were removed and used for individual induction furnace slag/metal melt tests. By tracking master ingot specimens used in the melt testing, the starting sample surrogate concentrations were known for each individual melt test. The flux requirement for each melt test was then prepared by weighing and mixing the ingredients required for each specific test. The carbon steel surrogate ingots were cut into approximately ( $900 \mathrm{gms}$ ) for subsequent melting experiments.

The metal sample was placed (usually approximatesly $400-900 \mathrm{gms}$ ) into the furnace crucible and its required flux poured around it (usually 2-5\% flux was added). Flux compositions (and flux designations) used in the laboratory scale test work are presented below:

"Borate"-30\% $\mathrm{SiO}_{2}, 40 \% \mathrm{CaO}, 10 \% \mathrm{Al}_{2} \mathrm{O}_{3}, 15 \% \mathrm{Fe}_{2} \mathrm{O}_{3}, 5 \% \mathrm{Ca}_{2} \mathrm{~B}_{6} \mathrm{O}_{11}$

"Borate" without Fe Oxide- $13 \% \mathrm{CaO}, 12 \% \mathrm{Al}_{2} \mathrm{O}_{3}, 68 \% \mathrm{CaSiO}_{3}, 7 \% \mathrm{Ca}_{2} \mathrm{~B}_{6} \mathrm{O}_{11}$

"Borate" without Borate- $32 \% \mathrm{SiO}_{2}, 10 \% \mathrm{Al}_{2} \mathrm{O}_{3}, 42 \% \mathrm{CaO}, 16 \% \mathrm{Fe}_{2} \mathrm{O}_{3}$

"Wollastonite"- $100 \% \mathrm{CaSiO}_{3}$

"Fluoride"- $30 \% \mathrm{SiO}_{2}, 40 \% \mathrm{CaO}, 10 \% \mathrm{Al}_{2} \mathrm{O}_{3}, 15 \% \mathrm{Fe}_{2} \mathrm{O}_{3}, 5 \% \mathrm{CaF}_{2}$

"Ferrite"-77.8\% $\mathrm{Fe}_{2} \mathrm{O}_{3}, 22.2 \% \mathrm{CaO}$

Calcium Fluoride-100\% $\mathrm{CaF}_{2}$. 
Once the furnace was loaded, furnace power was turned on and slowly increased to heat the metal charge without thermally stressing the crucible. Furnace power, current and frequency, temperature, and time were recorded throughout the heating and molten metal cycle. Once the charge was molten, furnace power was decreased to a level that would just maintain the rolling action. Operating the power output of the furnace in this manner minimized superheat. There was no obvious temperature gradient after the charge was molten.

Tests were conducted in an open atmosphere and in an argon atmosphere by flooding the crucible with argon. In the open atmosphere and argon melts, fumes that emanated from the furnace were removed from the optical pyrometer path by an exhaust system. Pyrometer accuracy was improved by using this procedure. Once molten metal/slag interaction times were satisfied, the molten slag/melt charge was poured into sacrificial crucibles that were pre-heated to $400^{\circ} \mathrm{C}$. The charge was then allowed to solidify and cool. Metal and slag samples were then taken and prepared for chemical characterization. (Worcester, et al, 1994)

Slag and metal phase surrogate analysis for both steel and stainless steel were primarily performed using Induction Coupled Plasma/Mass Spectrometry (ICP/MS). The slag sampling was performed in two ways, i.e., one method was to recover the slag from the cast metal and slag after cooling. A second method consisted of sampling the slag in the molten state by plunging a cold metal rod into the molten slag and quickly withdrawing the rod. The adhering slag was then recovered. The second sampling method was preferred because metal contamination from the molten charge was minimized. The slag was then pulverized and submitted for analysis. Metal phase samples were obtained by drilling the cast ingot with a $3 / 8$ " drill bit to remove any surface oxidized metal; then metal shavings were obtained for analysis by drilling into the interior of the casting with a 1/4" drill bit. Most of the analyses were performed by Teledyne-Wah Chang Albany using Induction Coupled Plasma Mass Spectrometry (ICP-MS).

\subsection{PRELIMINARY EXPERIMENTS}

Using an experimental plan designed to investigate decontamination effectiveness of the basic calcium-alumina-silicate slags, Montana Tech's initial melt campaign was performed following the melt/slag refining procedure as described in Section 3.1.5. The experiment control variables were flux composition, metal/slag mass ratio, time, gas atmosphere, and oxygen potential in the melt. Non-controllable variables were alumina and chromium oxide content, which were present as contaminant from furnace crucible dissolution, and oxygen, available from molten metal contact with the open atmosphere. Large scale melting described in the literature has been subject to these non-controllable variables, and most likely, also will production scale RSM recycling. The investigators wanted to match large scale decontamination efforts in the newly installed laboratory induction furnace, therefore, melting in a crucible in the open atmosphere was considered an acceptable experimental procedure. 


\subsubsection{PRELIMINARY EXPERIMENTS: METAL PHASE}

A series of 900 gram induction melts were performed by varying the time, temperature, and oxygen potential conditions. Thirty two laboratory scale experimental melts were performed on stainless and carbon steel in the induction furnace. The experimental results are presented in Tables 3.6 (for stainless steel) and 3.7 (for carbon steel). These melt tests provided quantitative information used to design the conditions for the larger pilot scale induction melt verification tests.

\section{TABLE 3.6. EXPERIMENTAL CONDITIONS AND ANALYTICAL RESULTS FOR THE STAINLESS STEEL INDUCTION MELTS AT MONTANA TECH}

\begin{tabular}{|c|c|c|c|c|c|c|c|c|}
\hline \multirow[t]{2}{*}{$\begin{array}{l}\text { EXPERIMENT } \\
\text { CHARGE } \\
\text { NUMBER } \\
\text { (FIGURE 3.5) }\end{array}$} & \multirow[t]{2}{*}{$\begin{array}{l}\text { TIME } \\
\text { (MIN) }\end{array}$} & \multirow[t]{2}{*}{$\begin{array}{c}\text { FLUX USED } \\
\text { (CHARGE\%) }\end{array}$} & \multicolumn{3}{|c|}{$\begin{array}{c}\text { SURROGATE IN METAL } \\
\text { PHASE, PPM } \\
\text { (Element subscript denotes } \\
\text { concentration in Master Alloy) }\end{array}$} & \multicolumn{3}{|c|}{$\begin{array}{c}\text { Cr, Mn, \& Si IN METAL } \\
\text { PHASE, WT.\% } \\
\text { (Element subscript denotes } \\
\text { concentration in Master Alloy }\end{array}$} \\
\hline & & & $\mathbf{L a}_{350}$ & $\mathrm{Ce}_{6000}$ & $\mathbf{N d}_{530}$ & $\mathrm{Cr}_{18.7}$ & $\mathrm{Mn}_{1.42}$ & $\mathbf{S i}_{0.63}$ \\
\hline \multicolumn{9}{|c|}{ Temperature $=1500 \pm 50^{\circ} \mathrm{C}$} \\
\hline $\mathrm{B} 5 \mathrm{~Tb}$ & 0.5 & $\begin{array}{c}\text { Borate } \\
\text { w/o } \\
\text { Fe Oxide } \\
(5 \%) \\
\end{array}$ & 15 & 49 & 37 & 18.7 & 1.29 & NA \\
\hline $\mathrm{T} 2 \mathrm{~Tb}^{(1)}$ & 0.5 & $\begin{array}{l}\text { Borate } \\
\text { w/o } \\
\text { Boron } \\
(5 \%) \\
\end{array}$ & 13 & 38 & 31 & 18.3 & 1.27 & NA \\
\hline B5Ta & 5 & Wollast. & 0.47 & 1.5 & 1.1 & 18.4 & 0.76 & NA \\
\hline BITa & 5 & $\begin{array}{l}\text { Fluoride } \\
(5 \%)\end{array}$ & 3.0 & 6.0 & 6.0 & 18.7 & 1.04 & NA \\
\hline $\mathrm{B} 4 \mathrm{Bb}$ & 5 & $\begin{array}{c}\text { Borate } \\
\text { w/o } \\
\text { Fe Oxide } \\
(5 \%) \\
\end{array}$ & 3.3 & 9.2 & 7.6 & 18.8 & 1.28 & NA \\
\hline M5Ba & 7 & $\begin{array}{c}\text { Borate } \\
\text { w/o } \\
\text { Fe Oxide } \\
(5 \%) \\
\end{array}$ & 1.6 & 6.9 & 4.5 & 18.6 & 0.17 & NA \\
\hline $\mathrm{B} 2 \mathrm{Bb}$ & 15 & $\begin{array}{c}\text { Borate } \\
\text { w/o } \\
\text { Fe Oxide } \\
(5 \%)\end{array}$ & $<1.0$ & 1.4 & 1.2 & 18.7 & 1.06 & NA \\
\hline
\end{tabular}




\begin{tabular}{|c|c|c|c|c|c|c|c|c|}
\hline \multirow[t]{2}{*}{$\begin{array}{l}\text { EXPERIMENT } \\
\text { CHARGE } \\
\text { NUMBER } \\
\text { (FIGURE 3.5) }\end{array}$} & \multirow[t]{2}{*}{$\begin{array}{l}\text { TIME } \\
\text { (MIN) }\end{array}$} & \multirow[t]{2}{*}{$\begin{array}{l}\text { FLUX USED } \\
\text { (CHARGE\%) }\end{array}$} & \multicolumn{3}{|c|}{$\begin{array}{c}\text { SURROGATE IN METAL } \\
\text { PHASE, PPM } \\
\text { (Element subscript denotes } \\
\text { concentration in Master Alloy) }\end{array}$} & \multicolumn{3}{|c|}{$\begin{array}{c}\text { Cr, Mn, \& Si IN METAL } \\
\text { PHASE, WT.\% } \\
\text { (Element subscript denotes } \\
\text { concentration in Master Alloy) }\end{array}$} \\
\hline & & & $\mathbf{L a}_{350}$ & $\mathrm{Ce}_{600}$ & $\mathbf{N d}_{\mathbf{5 3 0}}$ & $\mathrm{Cr}_{18.7}$ & $\mathbf{M n}_{1.42}$ & $\mathbf{S i}_{\mathbf{0 . 6 3}}$ \\
\hline $\mathrm{B} 3 \mathrm{Bb}$ & 0.5 & $\begin{array}{c}\text { Fluoride } \\
(5 \%)\end{array}$ & 11.0 & 24.0 & 22.0 & 18.5 & 1.22 & NA \\
\hline $\mathrm{B} 5 \mathrm{Bb}$ & 5 & $\begin{array}{c}\text { Borate } \\
\text { w/o } \\
\text { Fe Oxide } \\
(25 \%) \\
\end{array}$ & 2.0 & 4.0 & $<1.0$ & 18.9 & 0.95 & NA \\
\hline M5Ta & 4 & None & 0.55 & 2.40 & 2.20 & NA & NA & NA \\
\hline $\mathrm{M} 5 \mathrm{Bb}$ & 5 & $\begin{array}{c}\text { None } \\
\text { (Argon) }\end{array}$ & 1.80 & 14.0 & 6.20 & NA & NA & NA \\
\hline $\mathrm{B} 5 \mathrm{Mb}$ & 5 & $\begin{array}{c}\text { Borate } \\
(5 \%) \\
\end{array}$ & 1.60 & 6.60 & 5.10 & 18.2 & 1.02 & NA \\
\hline M5Tb & 5 & $\begin{array}{l}\text { Borate } \\
\text { w/o } \\
\text { Fe Oxide } \\
(5 \%)\end{array}$ & 1.60 & 6.30 & $<1.00$ & $\mathrm{NA}$ & NA & NA \\
\hline $\mathrm{B} 2 \mathrm{~Tb}^{(1)}$ & 5 & $\begin{array}{c}\text { Borate } \\
\text { w/o } \\
\text { Boron } \\
(5 \%) \\
\end{array}$ & $<1.0$ & $<1.0$ & $<1.0$ & 18.4 & 1.23 & NA \\
\hline $\mathrm{B} 4 \mathrm{Ta}^{(1)}$ & 15 & $\begin{array}{c}\text { Borate } \\
\text { w/o } \\
\text { Fe Oxide } \\
(5 \%) \\
\end{array}$ & $<0.5$ & $<1.0$ & $<2.0$ & $\begin{array}{c}18.2 \\
17.6^{*}\end{array}$ & $\begin{array}{l}1.08 \\
1.05^{*}\end{array}$ & $\begin{array}{l}0.111 \\
0.288^{*}\end{array}$ \\
\hline $\mathrm{T} 2 \mathrm{Mb}$ & 30 & $\begin{array}{l}\text { Borate } \\
\text { w/o } \\
\text { Boron } \\
(5 \%) \\
\end{array}$ & $<1.0$ & $<1.0$ & $<1.0$ & 17.5 & 0.87 & 0.055 \\
\hline \multicolumn{9}{|c|}{ Temperature 1600 to $1690^{\circ} \mathrm{C}$} \\
\hline B5Ma & 30 & $\begin{array}{c}\text { Borate } \\
\text { w/o } \\
\text { Fe Oxide } \\
(5 \%) \\
\end{array}$ & $<1.00$ & $<1.00$ & $<1.00$ & 16.6 & 0.52 & NA \\
\hline $\mathrm{B} 5 \mathrm{Ba}$ & 30 & $\begin{array}{c}\text { Borate } \\
(5 \%)\end{array}$ & $<1.00$ & $<1.00$ & $<1.00$ & 17.1 & 0.55 & NA \\
\hline \multicolumn{9}{|c|}{ Temperature $=1700 \pm 50^{\circ} \mathrm{C}^{(2)}$} \\
\hline $\mathrm{B} 6 \mathrm{~Tb}$ & 5 & $\begin{array}{c}\text { Borate } \\
\text { w/q } \\
\text { Fe Oxide } \\
(5 \%)\end{array}$ & $<1.00$ & $<1.00$ & $<1.00$ & 19.1 & 1.15 & NA \\
\hline
\end{tabular}




\begin{tabular}{|c|c|c|c|c|c|c|c|c|}
\hline \multirow{2}{*}{$\begin{array}{c}\text { EXPERIMENT } \\
\text { CHARGE } \\
\text { NUMBER } \\
\text { (FIGURE 3.5) }\end{array}$} & \multirow[t]{2}{*}{$\begin{array}{l}\text { TIME } \\
\text { (MIN) }\end{array}$} & \multirow[t]{2}{*}{$\begin{array}{c}\text { FLUX USED } \\
\text { (CHARGE\%) }\end{array}$} & \multicolumn{3}{|c|}{$\begin{array}{c}\text { SURROGATE IN METAL } \\
\text { PHASE, PPM } \\
\text { (Element subscript denotes } \\
\text { concentration in Master Alloy) }\end{array}$} & \multicolumn{3}{|c|}{$\begin{array}{c}\text { Cr, Mn, \& Si IN METAL } \\
\text { PHASE, WT.\% } \\
\text { (Element subscript denotes } \\
\text { concentration in Master Alloy) }\end{array}$} \\
\hline & & & $\mathbf{L a}_{350}$ & $\mathrm{Ce}_{6000}$ & $\mathrm{Nd}_{530}$ & $\mathrm{Cr}_{18.7}$ & $\mathbf{M} \mathbf{n}_{1.42}$ & $\mathbf{S i}_{\mathbf{0}, 63}$ \\
\hline $\mathrm{B} 6 \mathrm{Ba}$ & $5^{(3)}$ & $\begin{array}{c}\text { Borate } \\
\text { w/o } \\
\text { Fe Oxide } \\
(5 \%) \\
\end{array}$ & $<1.00$ & 2.40 & 1.90 & 18.6 & 1.15 & NA \\
\hline B3 $\mathrm{Ta}^{(1)}$ & 15 & $\begin{array}{l}\text { Borate } \\
\text { w/o } \\
\text { Fe Oxide } \\
(5 \%)\end{array}$ & $<1.0$ & $<1.0$ & $<1.0$ & 17.5 & 0.87 & 0.055 \\
\hline $\mathrm{T}_{8} \mathrm{~Tb}^{(1)}$ & 15 & No Flux & $<0.5$ & $<1.0$ & $<2.0$ & 17.2 & 0.81 & 0.121 \\
\hline $\mathrm{B} 1 \mathrm{~Tb}^{(1)}$ & 15 & $\begin{array}{c}\text { Ferrite } \\
(5 \%)\end{array}$ & $<0.5$ & $<1.0$ & $<1.0$ & $\begin{array}{r}15.9 \\
15.4^{*}\end{array}$ & $\begin{array}{c}0.59 \\
0.60^{*}\end{array}$ & $\begin{array}{l}0.017 \\
0.234^{*}\end{array}$ \\
\hline $\mathrm{T} 2 \mathrm{~B} b^{(1)}$ & 15 & $\begin{array}{c}\text { Calcium } \\
\text {-Fluoride } \\
(100 \%) \\
\end{array}$ & $<0.5$ & $<1.0$ & $<2.0$ & $\begin{array}{c}17.9 \\
18.1^{*}\end{array}$ & $\begin{array}{l}1.02 \\
1.25^{*}\end{array}$ & $\begin{array}{l}0.050 \\
0.520^{*}\end{array}$ \\
\hline $\mathrm{B} 6 \mathrm{Ta}^{(1)}$ & 15 & $\begin{array}{c}\text { Borate } \\
\text { w/o } \\
\text { Fe Oxide } \\
(5 \%) \\
\end{array}$ & $<0.5$ & $<1.0$ & $<2.0$ & 18.2 & 1.06 & 0.066 \\
\hline $\mathrm{B} 4 \mathrm{Ba}$ & 15 & $\begin{array}{c}\text { Borate } \\
\text { w/o } \\
\text { Fe Oxide } \\
(5 \%) \\
\end{array}$ & $<1.00$ & $<1.00$ & $<1.00$ & 17.8 & 0.64 & NA \\
\hline \multicolumn{9}{|c|}{ 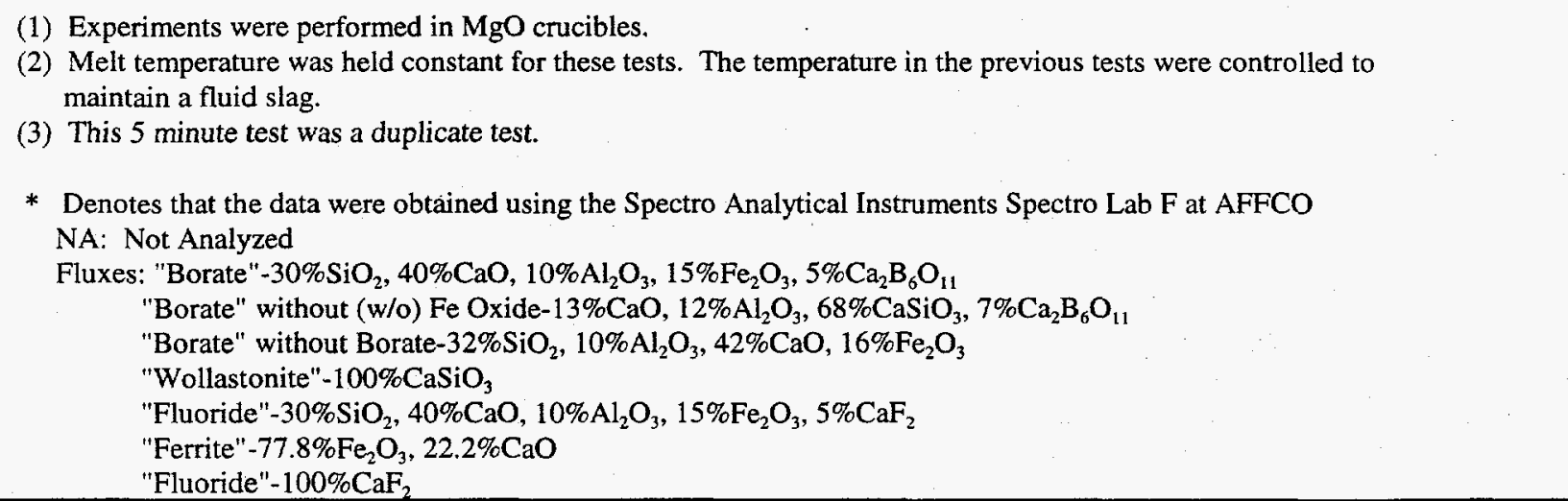 } \\
\hline
\end{tabular}

Conclusions drawn from the above stainless steel data include the following:

- Temperature and time are important variables. At least $1600^{\circ} \mathrm{C}$ is necessary for effective surrogate removal; $1500^{\circ} \mathrm{C}$ is too low. When at $1600^{\circ} \mathrm{C}$, five minute exposure is not sufficient for effective surrogate removal for any of the fluxes 
except the "Borate" (which contained ferric oxide), i.e., the stronger oxidizing condition provided by the ferric oxide does decontaminate the metal phase to $<1 \mathrm{ppm}$ for each surrogate. At fifteen and thirty minutes exposure the stronger oxidizing power of ferric oxide is not necessary to achieve effective surrogate removal, i.e., the "Borate" flux without ferric oxide was effective.

At $1700^{\circ} \mathrm{C}$, short time exposure is all that is necessary, i.e., times between 5-15 appear to be effective without ferric oxide present.

The overall conclusion concerning effective surrogate removal is that higher temperature and strong oxidizing conditions (i.e., stronger than just air exposure) are necessary for effective decontamination in very short time periods. However, slightly longer times at more moderate temperature levels produce effective surrogate removal with and without the presence of flux, i.e., air is all that is needed for effective surrogate removal.

- $\quad$ Chromium is only slightly removed at $1600^{\circ} \mathrm{C}$ (for short exposure times), in the presence of "Borate" with ferric oxide (same conditions that effectively removed the surrogates). Chromium removal increased with temperature and time but was a function of type flux used, e.g., note that at $1700^{\circ} \mathrm{C}$ using the "ferrite" flux the chromium content in the metal phase was decreased to approximately $15.4 \%$.

Manganese, in general, followed the same trend as chromium.

TABLE 3.7 EXPERIMENTAL CONDITIONS AND ANALYTICAL RESULTS FOR THE CARBON STEEL INDUCTION MELTS AT MONTANA TECH

\begin{tabular}{|c|c|c|c|c|c|c|c|}
\hline $\begin{array}{l}\text { TIME } \\
\text { (MIN) }\end{array}$ & $\begin{array}{c}\text { FLUX } \\
\text { USED }^{(1)}\end{array}$ & \multicolumn{5}{|c|}{$\begin{array}{l}\text { SURROGATE IN METAL PHASE, PPM } \\
\text { (Element subscript denotes concentration in Master Steel Ingot) }\end{array}$} & \multirow{2}{*}{$\begin{array}{c}\text { MN IN METAL } \\
\text { PHASE, Wt. \% } \\
\text { Mn }_{0,75}\end{array}$} \\
\hline & - & $\mathbf{L a}_{213}$ & $\mathrm{Ce}_{200}$ & $\mathbf{N d}_{205}$ & $\mathrm{Sr}_{2}$ & $\mathrm{Cs}_{\Delta L}$ & \\
\hline \multicolumn{8}{|c|}{ Temperature $=1600 \pm 50^{\circ} \mathrm{C}$} \\
\hline 5 & $(5 \%)$ & $<1.0$ & $<1.0$ & $<1.0$ & $<1.0$ & $<1.0$ & 0.23 \\
\hline 15 & $(5 \%)$ & $<1.0$ & $<1.0$ & $<1.0$ & $<1.0$ & $<1.0$ & 0.077 \\
\hline 30 & $(5 \%)$ & $<1.0$ & $<1.0$ & $<1.0$ & $<1.0$ & $<1.0$ & 0.021 \\
\hline \multicolumn{8}{|c|}{ Temperature $=1675 \pm 50^{\circ} \mathrm{C}$} \\
\hline 5 & $(5 \%)$ & $<1.0$ & $<1.0$ & $<1.0$ & $<1.0$ & $<1.0$ & 0.094 \\
\hline 15 & $(5 \%)$ & $<1.0$ & $<1.0$ & $<1.0$ & $<1.0$ & $<1.0$ & 0.044 \\
\hline 15 & $\begin{array}{l}\text { NO } \\
\text { FLUX }\end{array}$ & $<0.5$ & $<1.0$ & $<2.0$ & $<1.0$ & $<1.0$ & 0.26 \\
\hline
\end{tabular}


Conclusions drawn from the above carbon steel data include the following:

- For carbon steel, as anticipated, all melting conditions produced removal of surrogates to below one ppm.

\subsubsection{PRELIMINARY EXPERIMENTS: SLAGS}

Analyses were performed on only a portion of the slags produced by the above described series of experiments. The results are reported in Table 3.8.

Comments concerning the stainless steel slag data presented in Table 3.8:

- There is apparent contamination of the slag by crucible $\mathrm{MgO}$ in samples $\mathrm{T} 8 \mathrm{~Tb}$ and BTTb.

- Chromium is relatively high in all the slags and highest in the slag formed from the strongest oxidizing flux, i.e., the "Ferrite" flux. The same comment applies to manganese.

- $\quad$ Surrogates $(\mathrm{Ce}, \mathrm{La}, \mathrm{Nd})$ are present at much higher concentrations in the slag formed from the "Ferrite" flux. 
TABLE 3.8. SLAG ANALYSES FOR THE EXPERIMENTAL INDUCTION STAINLESS STEEL TESTS

\begin{tabular}{|c|c|c|c|c|c|c|c|c|}
\hline \multirow[b]{2}{*}{ ELEMENT } & \multicolumn{8}{|c|}{ SAMPLE ANALYZED } \\
\hline & $\begin{array}{c}\text { T8Tb } \\
\text { (No Flux) }\end{array}$ & $\begin{array}{l}\text { T2Bb } \\
\left(\mathbf{C a F}_{2}\right. \\
\text { Flux })\end{array}$ & $\begin{array}{c}\text { T2Bb } \\
\text { (Resample) }\end{array}$ & $\begin{array}{c}\text { B6Ta } \\
\text { (Borate, } \\
\text { w/o Ferric } \\
\text { Oxide) }\end{array}$ & $\begin{array}{c}\text { BTTb } \\
\text { (Ferrite } \\
\text { Flux) }\end{array}$ & $\begin{array}{c}\text { BTTb } \\
\text { (Resample) }\end{array}$ & $\begin{array}{c}\text { B3Ta } \\
\text { (Borate, } \\
\text { w/o Ferric } \\
\text { Oxide) }\end{array}$ & $\begin{array}{c}\text { B4Ba } \\
\text { (Borate, } \\
\text { w/o Ferric } \\
\text { Oxide) }\end{array}$ \\
\hline $\mathrm{Al} \%$ & $<0.1$ & $<0.1$ & $0.16 / 0.15$ & $<0.1$ & $<0.1$ & $0.18 / 0.23$ & $<0.1$ & $<0.1$ \\
\hline $\mathrm{Ca} \%$ & $<0.1$ & $<0.1$ & $0.45 / 0.58$ & $<0.1$ & $<0.1$ & $0.41 / 0.42$ & 1.3 & $<0.1$ \\
\hline $\mathrm{Co} \%$ & $<0.1$ & $<0.1$ & N.A. & $<0.1$ & $<0.1$ & N.A. & $<0.1$ & $<0.1$ \\
\hline $\mathrm{Cr} \%$ & 24.5 & 21.2 & N.A. & 15.6 & 45.4 & N.A. & 19.7 & 18.6 \\
\hline $\mathrm{Fe} \%$ & 28.2 & 41.6 & $31.0 / 31.5$ & 45.9 & 12.6 & $7.2 / 6.9$ & 43.9 & 45.3 \\
\hline $\mathrm{Mg} \%$ & 5.10 & 1.20 & N.A. & 0.19 & 5.40 & N.A. & 0.93 & 0.56 \\
\hline $\mathrm{Mn} \%$ & 4.50 & 2.40 & N.A. & 0.82 & 10.1 & N.A. & 3.30 & 1.30 \\
\hline Si $\%$ & 2.20 & 0.40 & N.A. & $<0.1$ & 0.90 & N.A. & 1.30 & 0.27 \\
\hline Ce ppm & 240 & 230 & N.A. & 83 & 1600 & N.A. & 390 & 150 \\
\hline La ppm & 130 & 130 & N.A. & 64 & 1100 & N.A. & 30 & 120 \\
\hline $\mathrm{Nd} \mathrm{ppm}$ & 220 & 210 & N.A. & 79 & 1600 & N.A. & 380 & 140 \\
\hline Sr ppm & $<5.0$ & 6.7 & N.A. & 9.7 & 14 & N.A. & 68 & $<5.0$ \\
\hline $\begin{array}{l}\%=\text { Weight } P e \\
\text { ppm }=\text { Parts Pe } \\
\text { N.A. = Not An }\end{array}$ & dion & & & & & & & \\
\hline
\end{tabular}




\subsubsection{SLAG CHARACTERIZATION AND GENERAL OBSERVATIONS}

Publications (from the computer data base search) did not report any final slag analyses or slag characterizations. The Montana Tech research team established the need to perform these procedures to determine element partitioning between slag constituents. Scanning Electron Microscopy/Energy Dispersive X-Ray Analysis (SEM/EDX) with standardless quantitative analysis software was used for the slag characterizations. Three slags, B5Ma, B5Tb and M5Tb were selected from the initial melt campaign for analysis. (Weldon, 1994)

Weldon (1994) reported in his M.Sc.Thesis the following: "Analysis of the slags show that dendrites high in chromium and manganese oxides exist in a variable composition matrix of $\mathrm{Ca}-\mathrm{Al}-\mathrm{Si}$ oxides along with varying amounts of chromium, manganese, and iron oxides. An SEM Digital Image of slag B5Ma is presented in Figure 3.6. In the image, the matrix is labeled "1", two metallic inclusions are labeled "3" and "6", and the dendritic oxide structures high in manganese and chromium are labeled "2", "4" and "5". Full standardless analyses for all numbered structures in the slag are located in Appendix B (Weldon, 1994), along with analyses obtained from slags B5Tb and M5Tb. All of the slags showed similar analyses and will be discussed collectively. It is assumed that all elements are present as oxides in the slag, except for metallic inclusions." (Weldon, 1994)

Surrogates cerium, lanthanum, and neodymium were detected in the slag matrix (composition varied over the range 0.28 to 1.76 weight percent). The surrogates cesium and strontium were not detected in any of the microstructural phases. SEM/EDX Standardless analysis provides only semiquantitative results and, therefore, the important result of this microstructural investigation is that the surrogates $\mathrm{Ce}, \mathrm{La}, \mathrm{Nd}$ are present in the matrix phase rather than in precipitated phases. However, this conclusion is only valid for the cooling conditions of the specific experiments. The microstructure present is, of course, very dependent on the rate at which the slag is cooled.

The matrix composition appears to vary with melt time (the chromium and manganese content in the three slag matrices increased with total melt time).

Dendrites high in chromium and manganese exist in the $\mathrm{Ca}-\mathrm{Al}-\mathrm{Si}$ oxide matrix. Chromium in the dendrites is present in the 49-59 weight percent range, manganese in the range 22-31 weight percent, and aluminum 3-7 weight percent (all based on oxide percentages). Surrogates were not detected in any of the dendrites. However, the present SEM/EDX system may not be able to detect the surrogates at very low concentrations, because of overlap problems between the Fe escape peak and the surrogate$\mathrm{La} \mathrm{L}_{\alpha}$ peaks. A voltage sufficient to excite the surrogate $\mathrm{K}_{\alpha}$ line (about $50-60 \mathrm{kV}$ ) was not available.

Oxidation potential and melt time may also effect the $\mathrm{Cr}-\mathrm{Mn}$ dendrite formation by increasing the size of the dendrites. Precipitated phases present in the slag were noted to be larger for longer melt times and higher oxygen potential fluxes melts than for the short time low oxygen potential melts. 


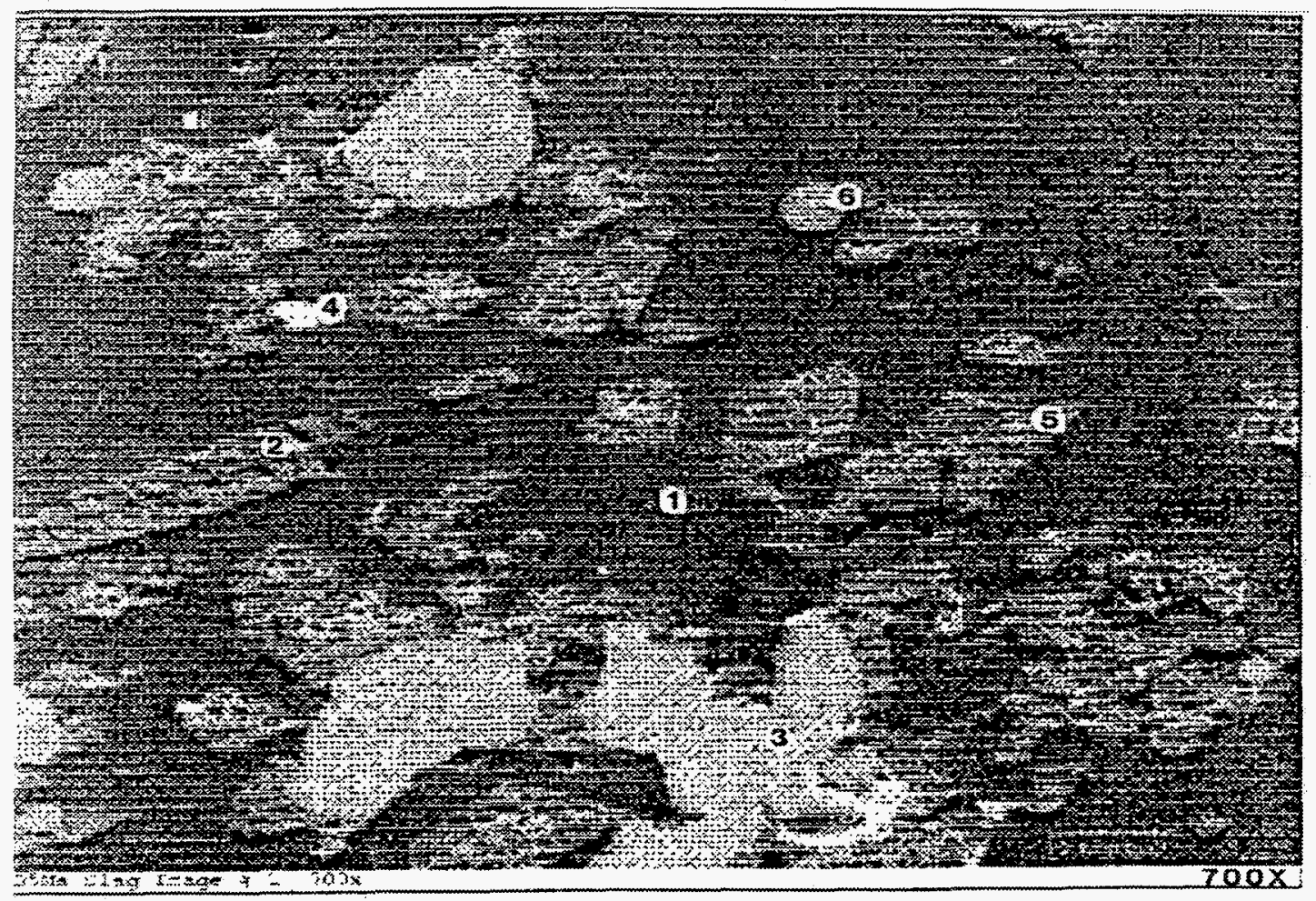

Figure 3.6. Digital SEM Image of Slag B5Ma. (Weldon, 1994)

Metallic inclusions were noted in the slags. The inclusions vary in composition from the starting metal to metallic particles that are essentially devoid of chromium and manganese. (Weldon, 1994)

\subsubsection{ANALYSIS OF CRUCIBLE CORROSION DURING STAINLESS STEEL INDUCTION EXPERIMENTAL TEST MELTS}

During the first melt campaign, ten stainless steel melts were made in a Scott-Ram 437A crucible for a total melt time of 100 minutes. Crucible wear for the entire program showed an average change in the crucible diameter of $0.077 \mathrm{~mm}$ per molten metal minute. These data were collected by measuring the diameter change at the molten metal/slag/crucible interface where there is the highest rate of crucible attack. Diametral corrosion was consistant over the entire diameter. Temperature varied from $1490^{\circ} \mathrm{C}$ during initial melting to $1690^{\circ} \mathrm{C}$ during two 30 minute open atmosphere melts.

It was initially estimated that the crucible could be enlarged by wear to a maximum diameter of 7.63 $\mathrm{cm}$ before system integrity was compromised. The melt program was discontinued after ten melts due to cracking at the top of the crucible. The crucible wear did not reach the maximum diameter of 7.63 $\mathrm{cm}$. Cracking occurred where the refractory failed to bond during densification. (Worcester, 1994). Later in the stainless steel melt campaign sacrificial fused $\mathrm{MgO}$ crucibles were utilized. The effects of crucible corrosion for the stainless steel melt campaign in $\mathrm{MgO}$ crucibles are presented in Table 3.9. 
TABLE 3.9. RESULTS OF THE MgO CRUCIBLE CORROSION FOR THE
STAINLESS STEEL MELT CAMPAIGN

\begin{tabular}{|c|c|c|c|c|c|}
\hline $\begin{array}{c}\text { EXPERIMENT } \\
\text { IDENTIFICATION }\end{array}$ & $\begin{array}{c}\text { CRUCIBLE } \\
\text { CORROSION, } \\
\text { CHANGE IN } \\
\text { CRUCIBLE } \\
\text { DIAMETER, cm } \\
\end{array}$ & $\begin{array}{l}\text { TIME, } \\
\text { MIN }\end{array}$ & $\mathrm{TEMP}^{\circ}{ }^{\circ} \mathrm{C}$ & $\begin{array}{l}\text { FLUX, } \\
\text { (Wt. \%) }\end{array}$ & $\begin{array}{c}\text { VISUAL } \\
\text { OBSERVATIONS }\end{array}$ \\
\hline $\mathrm{T} 2 \mathrm{~Tb}$ & 0.2 & 0.5 & 1500 & $\begin{array}{l}\text { Borate } \\
\text { w/o } \\
\text { Boron } \\
(5 \%) \\
\end{array}$ & $\begin{array}{l}\text { Excellent ingot } \\
\text { condition }\end{array}$ \\
\hline $\mathrm{B} 2 \mathrm{~Tb}$ & 0.2 & 5 & 1600 & $\begin{array}{l}\text { Borate } \\
\text { w/o } \\
\text { Boron } \\
(5 \%) \\
\end{array}$ & $\begin{array}{l}\text { Slag adhered to } \\
\text { metal, moderate } \\
\text { surface oxide } \\
\text { buildup }\end{array}$ \\
\hline $\mathrm{B} 4 \mathrm{Ta}$ & 1.0 & 15 & 1600 & $\begin{array}{c}\text { Borate } \\
(5 \%)\end{array}$ & $\begin{array}{l}\text { Slag adhered to } \\
\text { metal }\end{array}$ \\
\hline $\mathrm{T} 8 \mathrm{~Tb}$ & 0.3 & 15 & 1675 & None & $\begin{array}{c}\text { Excessive oxide } \\
\text { products on metal } \\
\text { surface } \\
\end{array}$ \\
\hline $\mathrm{T} 2 \mathrm{Bb}$ & 0.12 & 15 & 1675 & $\begin{array}{l}\text { Fluoride } \\
\qquad(5 \%)\end{array}$ & $\begin{array}{c}\text { Excessive oxide } \\
\text { products on metal } \\
\text { surface }\end{array}$ \\
\hline B6Ta & $\begin{array}{l}0.3- \\
1.3 \\
\end{array}$ & 15 & 1675 & $\begin{array}{c}\text { Borate } \\
(5 \%)\end{array}$ & $\begin{array}{l}\text { Slag adhered to } \\
\text { ingot }\end{array}$ \\
\hline B3Ta & $\begin{array}{l}0.3- \\
1.0 \\
\end{array}$ & 15 & 1675 & $\begin{array}{c}\text { Borate } \\
(5 \%)\end{array}$ & $\begin{array}{c}\text { Slag adhered to } \\
\text { ingot }\end{array}$ \\
\hline $\mathrm{B} 1 \mathrm{~Tb}$ & $\begin{array}{c}0.3- \\
1.0\end{array}$ & 15 & 1700 & $\begin{array}{l}\text { Ferrite } \\
(5 \%)\end{array}$ & $\begin{array}{l}\text { Slag adhered to } \\
\text { ingot, good ingot } \\
\text { condition }\end{array}$ \\
\hline $\begin{array}{l}\text { Flux: "Borate" without (w/o } \\
\text { "Borate"-30\% } \mathrm{SiO}_{2}, 40 \\
\text { "Fluoride"-100\% } \mathrm{CaF}_{2} \\
\text { "Ferrite"--77.8\% } \mathrm{Fe}_{2} \mathrm{O}_{3}\end{array}$ & $\begin{array}{l}2 \% \mathrm{SiO}_{2}, 10 \% \mathrm{Al}_{2} \mathrm{O} \\
0 \% \mathrm{Al}_{2} \mathrm{O}_{3}, 15 \% \mathrm{Fe}_{2} \mathrm{C} \\
\mathrm{OO}\end{array}$ & $\begin{array}{l}\mathrm{aO}, 16 \% \\
\mathrm{a}_{2} \mathrm{~B}_{6} \mathrm{O}_{11}\end{array}$ & & & \\
\hline
\end{tabular}

Crucible corrosion observations for the carbon steel campaign are summarized in Table 3.10.

TABLE 3.10. THE EFFECTS OF CRUCIBLE CORROSION FOR THE STEEL MELT CAMPAIGN

\begin{tabular}{|c|c|c|c|c|c|c|}
\hline $\begin{array}{c}\text { EXPERIMENT } \\
\text { IDENTIFICATION }\end{array}$ & $\begin{array}{c}\text { CRUCIBLE } \\
\text { CORROSION } \\
\text { (INCHES) }\end{array}$ & $\begin{array}{c}\text { TIME } \\
\text { (MIN) }\end{array}$ & $\begin{array}{c}\text { TEMPERATURE } \\
\left({ }^{\circ} \mathbf{C}\right)\end{array}$ & $\begin{array}{c}\text { FLUX } \\
\text { (Wt. \%) }\end{array}$ & $\begin{array}{c}\text { CARBON } \\
\text { CONTENT, } \\
\text { Wt.\% }\end{array}$ & COMMENTS \\
\hline STM8994-2 & 0.031 & 5 & 1600 & $5 \%$ & 0.02 & $\begin{array}{c}\text { Slag adhered to } \\
\text { both crucible and } \\
\text { metal, heavy ingot } \\
\text { porosity }\end{array}$ \\
\hline
\end{tabular}




\begin{tabular}{|c|c|c|c|c|c|c|}
\hline $\begin{array}{l}\text { EXPERIMENT } \\
\text { IDENTIFICATION }\end{array}$ & $\begin{array}{c}\text { CRUCIBLE } \\
\text { CORROSION } \\
\text { (INCHES) } \\
\end{array}$ & $\begin{array}{l}\text { TIME } \\
\text { (MIN) }\end{array}$ & $\begin{array}{c}\text { TEMPERATURE } \\
\left({ }^{\circ} \mathrm{C}\right)\end{array}$ & $\begin{array}{l}\text { FLUX }^{(1)} \\
(\mathbf{W t .} \%)\end{array}$ & $\begin{array}{c}\text { CARBON } \\
\text { CONTENT, } \\
\text { Wt. } \% \\
\end{array}$ & COMMENTS \\
\hline STM8994-3 & 0.062 & 15 & 1600 & $5 \%$ & 0.08 & $\begin{array}{c}\text { Slag adhered to } \\
\text { both crucible and } \\
\text { metal, heavy ingot } \\
\text { porosity }\end{array}$ \\
\hline STM8994-5 & 0.38 & 30 & 1600 & $5 \%$ & $<0.01$ & $\begin{array}{l}\text { Slag adhered to } \\
\text { crucible, good } \\
\text { ingot condition }\end{array}$ \\
\hline STM8994-4 & 0.12 & 15 & 1675 & $5 \%$ & 0.01 & $\begin{array}{c}\text { Slag adhered to } \\
\text { crucible, moderate } \\
\text { ingot porosity }\end{array}$ \\
\hline STM8994-6 & $\begin{array}{l}0.12- \\
0.38\end{array}$ & 5 & 1675 & $5 \%$ & 0.10 & $\begin{array}{l}\text { Slag adhered to } \\
\text { crucible, fair } \\
\text { ingot condition }\end{array}$ \\
\hline STM72694-1 & 0.062 & 15 & 1675 & None & 0.26 & $\begin{array}{c}\text { Slag adhered to } \\
\text { both crucible and } \\
\text { metal, ingot } \\
\text { porosity }\end{array}$ \\
\hline
\end{tabular}

Crucible/slag corrosion comments are presented below:

- The expected trend of increased corrosion for longer melt times and higher melt temperatures was confirmed.

- Slag/crucible interaction increased for the MgO crucibles when the "borate" flux was used as compared to no flux in the melt, B3Ta/B6Ta versus T8Tb.

- $\quad$ Every MgO crucible thermally cracked during the melting process; therefore, $\mathrm{MgO}$ crucibles were not recommended for the subsequent pilot scale studies.

\subsection{ATTAINMENT OF THE LABORATORY TEST WORK GOALS}

As stated previously the goals set forth for the laboratory experimental program included:

- The development of a test protocol for induction melt decontamination that results in lowering each surrogate concentration to less than one part per million.

- The determination of the importance of several experimental variables prior to conducting larger demonstration verification tests. The variables investigated included: time, temperature, and flux composition. 
The stated goals have been achieved. A test protocol has been developed for treating surrogate bearing carbon and stainless steel that results in attaining surrogate concentrations that are less than one milligram per kilogram of steel, i.e., $1 \mathrm{ppm}$. This protocol has been applied to larger scale demonstration verification melts with successful results (described in Sections 4.1 and 4.2). 


\title{
DECONTAMINATION AND DECARBURIZATION OF STAINLESS STEEL
}

AND

CARBON STEEL BY MELT REFINING

\author{
SECTION FOUR \\ STAINLESS STEEL PILOT AND COMMERCIAL SCALE TEST WORK
}

\subsection{PILOT SCALE PLASMA AND VACUUM INDUCTION MELTING TEST PROGRAM}

Two pilot scale melt programs were conducted; one utilizing a two torch cold hearth plasma melt furnace and one utilizing a vacuum induction furnace. A description of the facilities, test procedures and test results are presented and discussed below. The intent of the pilot scale test work was to demonstrate that the basic information generated during the laboratory scale test work could be utilized in pilot scale tests and subsequently in commercial scale treatment systems.

\subsubsection{GOALS OF THE PILOT SCALE TEST WORK}

The goals of the pilot scale stainless steel test work included:

- The evaluation of whether effective surrogate removal could be accomplished using plasma torch melting under controlled oxidation potential conditions (applied to approximately two hundred pounds of surrogate-loaded stainless steel).

- The evaluation of whether effective surrogate removal and carbon reduction could be accomplished without appreciable chromium loss by vacuum induction melting (VIM) under controlled oxygen potential (applied to approximately two hundred pounds of surrogate-loaded stainless steel).

\subsubsection{PLASMA PILOT SCALE MELT TEST PROGRAM}

A number of experimental tests were performed in the RETECH (Ukiah, California) facility. Master alloy ingots were melted in various gaseous environments with and without the present of flux materials (i.e., the oxidizing potential in the tests was varied over a wide range) to investigate the degree of surrogate removal by controlling the oxidizing potential during the period. The melt procedure and the test results are presented in the following sections. The same plasma facility was utilized for this test program as that utilized for the preparation of the Master Ingots (See Section 3.4.1.)

\subsubsection{DESCRIPTION OF THE MELT PROCEDURE}

The melt procedure described previously for preparation of the Master Ingot (Section 3.4.1) is essentially the same procedure utilized for conducting the plasma controlled oxidation test work. 
The major differences were that the gas atmosphere was modified and/or flux material was added to the melt chamber in order to control the oxidizing potential in the furnace environment. A detailed description of the melt procedure is presented by Paolini (1995) in his M.Sc. thesis. For the purposes of this report the initial conditions and melt procedure are described individually for each test in the following sections.

\subsubsection{CONTROLLED OXIDATION MELT WITH AN OXIDIZING FLUX}

A series of tests were conducted at RETECH in Ukiah, California utilizing their two torch plasma cold hearth melting facility. The experimental test program and results are summarized in the following sections.

\subsection{INITIAL CONDITIONS FOR FIRST MELT/FLUX EXPERIMENT}

The first pilot scale surrogate-removal melt was performed March 3, 1994 at RETECH, Inc. This test was designed to examine the effect of oxidation potential (by controlling flux addition) in removing surrogates $\mathrm{La}, \mathrm{Nd}, \mathrm{Ce}, \mathrm{Sr}$, and $\mathrm{Cs}$ from stainless steel without crucible interaction. The oxidation potential was controlled in the test by addition of the following fluxes:

- $\quad$ Stage One: No flux present (reference stage)

- $\quad$ Stage Two: "Borate" flux without ferric oxide

- $\quad$ Stage Three: "Borate" flux.

The melt test was conducted in RETECH's two-torch cold hearth plasma furnace in a helium atmosphere. Using this facility, the oxidizing potential of the slag could be assessed without interference from crucible material (because the hearth and mold crucible were both water cooled copper) and atmospheric gases. The procedure used consisted of melting approximately 30 kilograms of stainless steel without flux (Stage One), then melting a similar amount of stainless steel doped with an oxidizing flux (Stage Two); then melting a similar amount of stainless steel doped with a more oxidizing flux (Stage Three). Stage One and Two melting was conducted sequencially without stopping. The melting was then discontinued and the system opened up so that a slag sample could be collected after Stage Two melting. The system was then closed and Stage Three melting was performed.

In Stage One 32 kilograms of stainless steel feedstock was melted in the presence of packets of surrogate containing elements. No flux was present. Stage One melting had two purposes, i.e., to fill the hearth with surrogate containing metal and to demonstrate that melting stainless steel feedstock with surrogates would produce a high surrogate containing metal phase (similar to the master alloy in surrogate content). The major goal of Stage One was to demonstrate that the furnace helium (nonoxidizing) atmosphere was not oxidizing enough to oxidize the surrogates. 
the metal phase for surrogate content provided the reference state for determining the effect of flux additions.

In Stage Two a 45.4 kilogram section of feedstock (containing surrogate packets) plus $2 \%$ flux without the presence of iron oxide $\left(11.8 \% \mathrm{Al}_{2} \mathrm{O}_{3}, 35.3 \% \mathrm{SiO}_{2}, 49.1 \% \mathrm{CaO}\right.$, and $\left.3.8 \% \mathrm{~B}_{2} \mathrm{O}_{3}\right)$ was melted. The purpose of Stage Two melting was to demonstrate that a mildly oxidizing flux would result in at least partial surrogate removal.

In Stage Three a 45.4 kilogram section of feedstock (containing surrogate packets) plus $2 \%$ "Borate" flux containing $15 \%$ iron oxide $\left(10 \% \mathrm{Al}_{2} \mathrm{O}_{3}, 30 \% \mathrm{SiO}_{2}, 41.8 \% \mathrm{CaO}, 3.2 \% \mathrm{~B}_{2} \mathrm{O}_{3}\right.$ and $\left.15 \% \mathrm{Fe}_{2} \mathrm{O}_{3}\right)$ was melted. The purpose of Stage Three melting was to demonstrate that a more aggressive oxidizing flux would result in greater surrogate removal.

Surrogates were added to the melt stock (during the melting process) in the same manner used for the master melt described in Section 3.4.1. Flux was present in 6.4 centimeter diameter Type 304 stainless steel tubes (attached to the ingot) that melted as the ingot was fed to the torches. Calcium borate was present as "Gerstley Borate," calcium silicate as "Wollastonite $\left(100 \% \mathrm{CaSiO}_{3}\right)$," aluminum oxide as alumina and iron oxide as ferric oxide. (Worcester, 1994)

The ingot was continuously fed to a torch that melted the metal into a water cooled hearth. The rate of metal feed was controlled by this torch. The melt rate was held to approximately 20 centimeters/hour at steady state. The metal pool was kept molten by continuously exposing the hearth metal to the hearth torch. Periodically the hearth metal was fed into an extractable-bottom mold by melting a hearth dam of solidified metal that existed between the hearth and the extractablebottom ingot crucible. The metal in the ingot mold was kept molten by a second torch that continuously rotated over the surface of the mold metal.

\subsection{TEST RESULTS}

Results from these tests showed less effective surrogate removal than that achieved during the laboratory air induction melt study. Analytical results for the metal and slag phases are presented in Tables 4.1 and 4.2 respectively. (Weldon, 1994)

\subsection{METAL ANALYSES}

Analysis of the metal phase revealed that decontamination levels achieved in the previous open atmosphere induction melts were not met by this test series; even though the oxygen potentials supplied by the fluxes in Stages Two and Three were calculated (by the CSIRO/MONASH program) to be sufficient to oxidize all of the surrogates from the melt. Metal phase analyses were performed using ICP-MS. 


\section{TABLE 4.1. FIRST FLUX CONTROLLED OXIDATION METAL PHASE ANALYSES}

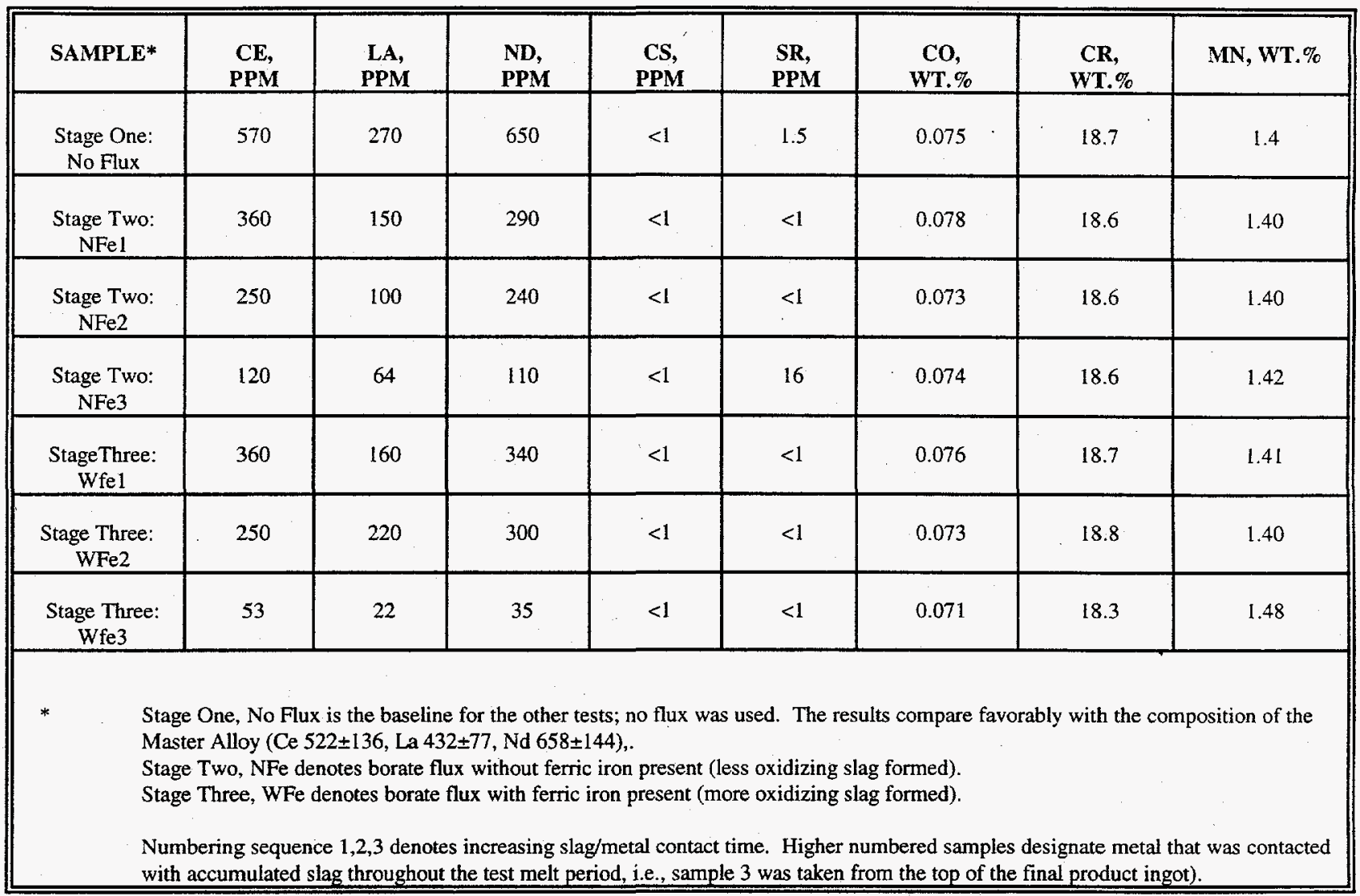

Comments concerning the test results are presented below:

- The concentration of surrogates in the stainless steel in the absence of fluxing agents compared favorably with the results obtained for the preparation of the "Master" alloy utilized in the previous laboratory induction tests.

- Increasing oxygen potential in the system increased surrogate removal from the melt. Final surrogate concentrations for the "Borate" flux containing ferric oxide were lower (Ce $53 \mathrm{ppm}, \mathrm{La} 22 \mathrm{ppm}$, and Nd $35 \mathrm{ppm}$ ) compared to the final surrogate concentrations for the non-ferric oxide containing "Borate" flux (Ce 120 ppm, La 64 ppm, and Nd 110 ppm). This trend was anticipated based on thermodynamic calculations. However, it was anticipated that lower surrogate concentrations would be achieved for both slag exposures.

- Slag/Metal contact time had a significant effect on the surrogate removal efficiency of the slags. For both of the borate slags, surrogate removal was not as effective as open air atmosphere melting in induction furnace systems. 
furnace. For the same contact time during induction melting less than $1 \mathrm{ppm}$ surrogate concentrations were achieved.

- $\quad$ Sr and Cs were significantly removed from the metal phase simply by melting the stainless steel. Sr and Cs concentrations were $<1.0$ and $1.5 \mathrm{ppm}$, respectively, without the addition of flux. The flux addition to the melt brought the Sr concentration to below $1 \mathrm{ppm}$. Sample NFe3, one of the highest oxygen potential samples, showed $\mathrm{Sr}$ at $16 \mathrm{ppm}$, but this sample result is inconsistent with all the other results.

- Co concentration in the metal phase remained constant throughout all stages of the controlled oxidation testing.

- $\quad \mathrm{Cr}$ and Mn concentrations in the metal phase did not appear to be affected by the oxidizing action of the slag. However, both are shown to be present at significant concentrations in analysis of the slag phase. (Weldon, 1994)

\subsection{SLAG ANALYSES}

All slag samples were collected from the indicated areas of Figure 4.1 for the RETECH plasma melts. The slag generally was loose on the metal surface except around the outer edges of the hearth. The slag analytical results are presented in Table 4.2.

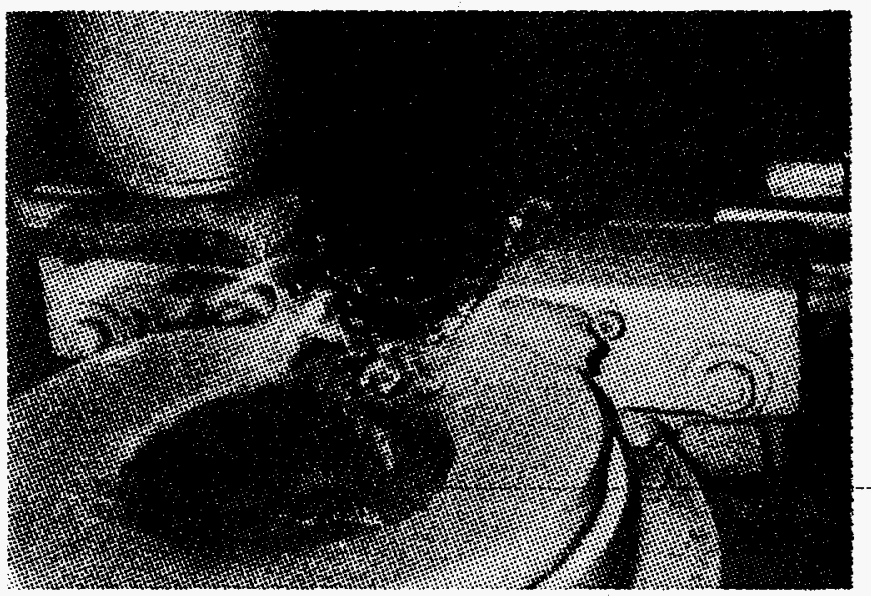

Hearth Slag

Crucible Slag

Figure 4.1. Slag Collection Points from the Retech Plasma Furnace

TABLE 4.2. FLUX CONTROLLED OXIDATION SLAG ANALYSES 


\section{TABLE 4.2. FLUX CONTROLLED OXIDATION SLAG ANALYSES (WELDON, 1994)}

\begin{tabular}{|c|c|c|c|c|}
\hline & \multicolumn{4}{|c|}{ SAMPLE } \\
\hline & $\begin{array}{c}\text { Hearth Slag } \\
\text { (Borate Flux } \\
\text { Without Iron } \\
\text { Oxide) } \\
\end{array}$ & $\begin{array}{c}\text { Crucible Slag } \\
\text { (Borate Flux } \\
\text { Without Iron } \\
\text { Oxide) } \\
\end{array}$ & $\begin{array}{c}\text { Crucible Slag } \\
\text { (Borate Flux } \\
\text { With Iron } \\
\text { Oxide) } \\
\end{array}$ & $\begin{array}{c}\text { Hearth Slag } \\
\text { (Borate Flux } \\
\text { Without Iron } \\
\text { Oxide) } \\
\end{array}$ \\
\hline Mass,(grams) & 981 & 65 & 920 & 340 \\
\hline \multicolumn{5}{|c|}{ Starting Flux Composition* } \\
\hline $\mathrm{SiO}_{2}(\mathrm{Wt} . \%)$ & 35 & 35 & 30 & 30 \\
\hline $\mathrm{CaO}$ (Wt.\%) & 49 & 49 & 42 & 42 \\
\hline $\mathrm{Al}_{2} \mathrm{O}_{3}(\mathrm{Wt} . \%)$ & 12 & 12 & 10 & 10 \\
\hline $\mathrm{Fe}_{2} \mathrm{O}_{3}(\mathrm{Wt} . \%)$ & - & - & 15 & 15 \\
\hline $\mathrm{B}_{2} \mathrm{O}_{3}(\mathrm{Wt} . \%)$ & 4 & 4 & 3 & 3 \\
\hline \multicolumn{5}{|c|}{ Controlled Oxidation Melt Final Slag Composition: X-Ray Fluorescence } \\
\hline $\mathrm{Al}(\%)$ & 4.6 & 4.6 & 4.5 & 3.5 \\
\hline $\mathrm{Ca}(\%)$ & 18.4 & 18.3 & 18.1 & 14.1 \\
\hline $\mathrm{Si}(\%)$ & 22.0 & 27.2 & 32.6 & 23.5 \\
\hline $\mathrm{Cr}(\%)$ & 0.6 & 0.6 & 1.1 & 0.8 \\
\hline $\operatorname{Mn}(\%)$ & 1.1 & 1.1 & 1.9 & 1.6 \\
\hline $\mathrm{Fe}(\%)$ & 0.6 & 0.6 & 0.7 & 0.5 \\
\hline $\mathrm{Ni}(\mathrm{ppm})$ & 348 & 143 & 45 & 331 \\
\hline Sr (\%) & 2.5 & 2.3 & 3.0 & 6.8 \\
\hline Cs (ppm) & 60 & $<15$ & 18 & 300 \\
\hline $\mathrm{Ce}(\%)$ & 2.7 & 2.5 & 2.8 & 5.0 \\
\hline $\mathrm{La}(\%)$ & 2.7 & 2.5 & 2.8 & 6.2 \\
\hline $\mathrm{Nd}(\%)$ & 2.9 & 2.5 & 2.7 & 6.3 \\
\hline $\mathrm{Co}(\mathrm{ppm})$ & 31 & 34 & $<15$ & $<15$ \\
\hline \multicolumn{5}{|c|}{$\begin{array}{l}\text { REFINED METAL INGOTS MAJOR SLAG CONSTITUENTS AS } \\
\text { OXIDES: SEM/EDX STANDARDLESS QUANTITATIVE ANALYSIS }\end{array}$} \\
\hline $\mathrm{Al}_{2} \mathrm{O}_{3}(\mathrm{Wt} . \%)$ & 9.8 & 9.4 & 8.4 & 7.6 \\
\hline
\end{tabular}




\begin{tabular}{|c|c|c|c|c|}
\hline & \multicolumn{4}{|c|}{ SAMPLE } \\
\hline & $\begin{array}{c}\text { Hearth Slag } \\
\text { (Borate Flux } \\
\text { Without Iron } \\
\text { Oxide) } \\
\end{array}$ & $\begin{array}{c}\text { Crucible Slag } \\
\text { (Borate Flux } \\
\text { Without Iron } \\
\text { Oxide) } \\
\end{array}$ & $\begin{array}{c}\text { Crucible Slag } \\
\text { (Borate Flux } \\
\text { With Iron } \\
\text { Oxide) } \\
\end{array}$ & $\begin{array}{c}\text { Hearth Slag } \\
\text { (Borate Flux } \\
\text { Without Iron } \\
\text { Oxide) } \\
\end{array}$ \\
\hline $\mathrm{CaO}(\mathrm{Wt} . \%)$ & 45.0 & 40.4 & 41.1 & 35.5 \\
\hline $\mathrm{SiO}_{2}(\mathrm{Wt} . \%)$ & 29.9 & 26.7 & 30.1 & 29.8 \\
\hline $\mathrm{Cr}_{2} \mathrm{O}_{3}(\mathrm{Wt} . \%)$ & 2.1 & 2.0 & 3.0 & 2.4 \\
\hline $\mathrm{MnO}(\mathrm{Wt} . \%)$ & 1.8 & 1.6 & 2.6 & 2.4 \\
\hline $\mathrm{FeO}(\mathrm{Wt} . \%)$ & 2.6 & 11.8 & 4.9 & 4.8 \\
\hline $\mathrm{Ce}_{2} \mathrm{O}_{3}(\mathrm{Wt} . \%)$ & 2.9 & 2.5 & 3.2 & 5.0 \\
\hline $\mathrm{La}_{2} \mathrm{O}_{3}(\mathrm{Wt} . \%)$ & 3.0 & 2.8 & 3.2 & 6.6 \\
\hline $\mathrm{Nd}_{2} \mathrm{O}_{3}(\mathrm{Wt} . \%)$ & 2.8 & 2.7 & 3.4 & 6.0 \\
\hline $\begin{array}{l}\text { Flux was ad } \\
\text { The resultan } \\
\text { cumulativel } \\
\text { The cumula } \\
\text { without iron }\end{array}$ & $\begin{array}{l}\text { rate equivalent t } \\
\text { as not continuall } \\
\text { the hearth and } 0\end{array}$ & $\begin{array}{l}\text { weight percent o } \\
\text { oved from the pla } \\
\text { le molten metal } p \\
\text { using } 2 \% \text { "Bora } \\
5 \text { grams, respecti }\end{array}$ & $\begin{array}{l}\text { material. } \\
\text {-arc furnace, but } \\
\text { until all feed wo } \\
\text { rith iron oxide a }\end{array}$ & $\begin{array}{l}\text { allowed to } \\
\text { sumed. } \\
\text { "Borate" }\end{array}$ \\
\hline
\end{tabular}

The following comments concerning the test results are presented below:

- $\quad$ Significantly more surrogate was recovered from the metal phase for the "Borate" flux containing ferric oxide (based on the hearth slag). This effect was noted for all of the surrogates.

- $\quad \mathrm{Cr}$ and $\mathrm{Mn}$ were present in the slag phase and their concentrations increased with increasing oxidation potential of the flux. The metal analytical data showed no loss of chromium or manganese as a function of oxidizing potential (within the reproduciblity of the data). The differences are likely due to the fact that a small loss of chromium and manganese from a large mass of metal (approximately 40 kilograms of metal) resulted in measureable amounts in the small mass of slag (approximately 1200 grams).

- Ferric oxide added as flux was significantly reduced in concentration during the treatment process (indicating that it served its purpose as an oxidant).

- The final slag composition varied little for the major constituents from the starting 
flux, with only minor additions of chromium, manganese, and surrogate oxides. (Weldon, 1994)

\subsection{DISTRIBUTION RATIO}

Distribution ratios were calculated for the samples NFe3, and WFe3 and the values are presented in Table 4.3. The distribution ratio is defined as follows:

Distribution Ratio $=$

[Surrogate in the slag, ppm]/[Surrogate in the metal, ppm]

For example the D.R. for NFe3 is

D.R. $($ for $\mathrm{Ce})=25000 / 120=208$

Note that the distribution ratio values are higher for the WFe 3 exposure, i.e., the flux containing ferric oxide was more oxidizing to the surrogate elements than the flux without ferric oxide.

TABLE 4.3. DISTRIBUTION RATIOS FOR THE FIRST RETECH FLUX CONTROLLED OXIDATION MELT

\begin{tabular}{|c|c|c|c|c|c|}
\hline Sample & Ce & La & Nd & Cs & Sr \\
\hline NFe3 & 208 & 385 & 74 & N.A. & 1438 \\
\hline WFe3 & 528 & 1273 & 771 & N.A. & N.A. \\
\hline N.A. = Not Available \\
\hline
\end{tabular}

\subsubsection{SECOND CONTROLLED OXIDATION MELT WITH AN OXIDIZING FLUX}

\subsection{INITIAL CONDITIONS FOR MELT/FLUX EXPERIMENT}

The second pilot scale controlled oxidation test was performed at RETECH, Inc. on May 26-27, 1994. This pilot scale test was similar to the first pilot scale test for controlling the oxygen potential with fluxes. The fluxes for this test series were chosen to provide more aggressive oxidizing conditions than were used in the first test series. The flux compositions for this test series consisted of the following:

- $\quad$ "Borate" Flux (5 wt.\% added) with ferric oxide $\left(10 \% \mathrm{Al}_{2} \mathrm{O}_{3}, 15 \% \mathrm{Fe}_{2} \mathrm{O}_{3}, 5.9 \% \mathrm{Ca}_{2} \mathrm{~B}_{6} \mathrm{O}_{11}, 58 \% \mathrm{CaSiO}_{3}, 11.1 \% \mathrm{CaO}\right)$ 
- $\quad$ "Ferrite" Flux ( $5 \mathrm{Wt} . \%$ added)

$\left(77.8 \% \mathrm{Fe}_{2} \mathrm{O}_{3}, 22.2 \% \mathrm{CaO}\right)$

The ferrite flux had the higher oxidizing potential.

The test melt was conducted in RETECH's two torch cold crucible plasma furnace. The two product ingots from the first controlled oxidation melt were remelted at the increased oxidation potentials to determine if additional surrogates could be removed. The melt stock consisted of the two 15.2 centimeter diameter, 45-kilogram ingots with fluxing agents tacked onto the sides in sealed stainless steel tubes. Additional compacted "Borate" flux (in a stainless steel container) was placed on the skull (the hearth metal that remained after the first test series) to provide the proper desired flux/metal ratio. During the melt, the molten metal and flux cover in the cold copper ingot crucible was magnetically stirred throughout the test period. The feedstock melt rate was held to approximately 20 centimeters/hour at steady state. The molten layer in the crubible ingot was maintained in the liquid state for an additional 30 minutes after all the feedstock had been transferred to the crucible. This "soaking" period was achieved by placing both torches over the top of the liquid in the mold crucible.

After the "Borate" exposure was complete the test was terminated and the product ingot and slag were recovered. The system was then closed and the second exposure utilizing "Ferrite" flux was conducted in a similar manner to the "Borate" exposure. The only noted difference between the two tests was that the soaking period for the "Ferrite" exposure was forty minutes.

\subsection{TEST RESULTS}

\subsection{METAL ANALYSES}

During the "soaking" period for the "Borate" test at least 3.8 centimeters of slag covered the crucible. It was anticipated that the extra 30 minutes of molten metal/slag contact should have allowed for adequate oxidation of the surrogates, but as the metal analysis (presented in Table 4.4) show the surrogate concentrations were still above $1.0 \mathrm{ppm}$.

TABLE 4.4. METAL ANALYSES FOR SECOND FLUX CONTROLLED OXIDATION MELT

\begin{tabular}{||c|c|c|c|c||}
\hline \multirow{3}{*}{ ELEMENT } & \multicolumn{4}{|c||}{ SAMPLE ANALYZED } \\
\cline { 2 - 5 } & \multicolumn{3}{|c||}{ BORATE FLUX } & \multicolumn{2}{c|}{ FERRITE FLUX } \\
\cline { 2 - 5 } & M52694T & M52694S & M52794T & M52794S \\
\hline Co \% & 0.071 & 0.064 & 0.068 & 0.065 \\
\hline Cr \% & 18.8 & 19.1 & 17.7 & 18.5 \\
\hline
\end{tabular}




\begin{tabular}{|c|c|c|c|c|}
\hline \multirow{3}{*}{ ELEMENT } & \multicolumn{4}{|c|}{ SAMPLE ANALYZED } \\
\hline & \multicolumn{2}{|c|}{ BORATE FLUX } & \multicolumn{2}{|c|}{ FERRITE FLUX } \\
\hline & M52694T & M52694S & M52794T & M52794S \\
\hline $\mathrm{Mn} \%$ & 1.31 & 1.27 & 0.91 & 1.07 \\
\hline Ce ppm & 30 & 14 & 22 & $8.0^{\circ}$ \\
\hline Cs ppm & $<0.5$ & $<0.5$ & $<0.5$ & $<0.5$ \\
\hline La ppm & 19 & 4.9 & 14 & 4.8 \\
\hline $\mathrm{Nd} \mathrm{ppm}$ & 24 & 13 & 20 & 7.8 \\
\hline Sr ppm & 8.7 & $<0.5$ & 4.5 & 0.8 \\
\hline \multicolumn{5}{|c|}{$\begin{array}{l}\%=\text { Weight percent } \\
\text { ppm = Parts Per Million } \\
\text { Sample Identification: M52694T-Borate; metal from top of crucible ingot } \\
\qquad \begin{array}{l}\text { M52694S-Borate; metal from side of ingot } \\
\text { M52794T-Ferrite metal from top of ingot } \\
\text { M52794S-Ferrite metal from side of ingot }\end{array}\end{array}$} \\
\hline
\end{tabular}

Comments concerning the test results are presented below:

- Surrogate concentrations in the product ingots were significantly decreased from the starting concentrations. The surrogate concentrations at the slag/metal ingot surface were not very different in this test than in the First Flux Controlled Oxidation Melt test (for "Borate" with ferric oxide), i.e., the much greater oxidizing conditions supplied by the fluxes in the Second Flux Controlled Melts were not much more effective than the less aggressive oxidizing conditions supplied by the fluxes in the First Flux Controlled Melts.

- $\mathrm{Ce}, \mathrm{La}, \mathrm{Nd}$, and Sr were all present at higher concentrations in the top of the ingot (compared to the samples taken from the side of the ingot) irregardless of the flux used.

- Some chromium and manganese was lost from the steel. A greater loss was produced by the more oxidizing conditions of the "Ferrite" flux.

\subsection{SLAG ANALYSES}

The "Borate" slag had a much higher fluidity than the "Ferrite" slag. The quantity of slag recovered from product ingot using 5\% "Borate" flux and 5\% "Ferrite" flux was 1832 and 3124 grams, respectively. The slag phase analyses are presented in Table 4.5 . 
TABLE 4.5. SLAG ANALYSES OF SECOND FLUX CONTROLLED OXIDATION MELT

\begin{tabular}{|c|c|c|c|c|}
\hline \multirow{3}{*}{ ELEMENT } & \multicolumn{4}{|c|}{ SAMPLE ANALYZED } \\
\hline & \multicolumn{2}{|c|}{ BORATE FLUX } & \multicolumn{2}{|c|}{ FERRITE FLUX } \\
\hline & S52694H & S52694I & S52794H & S52794I \\
\hline $\mathrm{Al}(\%)$ & 5.41 & 1.41 & 5.57 & 1.09 \\
\hline $\mathrm{B}(\%)$ & 0.44 & 0.17 & 0.17 & 0.13 \\
\hline $\mathrm{Ca}(\%)$ & 30.4 & 19.0 & 33.4 & 16.8 \\
\hline $\mathrm{Cr}(\%)$ & 2.84 & 10.8 & 1.99 & 11.2 \\
\hline $\mathrm{Fe}(\%)$ & 0.39 & 6.91 & 0.31 & 5.64 \\
\hline $\operatorname{Mn}(\%)$ & 3.33 & 7.16 & 2.21 & 7.06 \\
\hline Mo $(\%)$ & $<0.05$ & $<0.05$ & $<0.05$ & $<0.05$ \\
\hline $\mathrm{Na}(\mathrm{ppm})$ & $<150$ & $<150$ & $<150$ & $<150$ \\
\hline $\mathrm{Nb}(\%)$ & $<0.05$ & 0.11 & 0.06 & 0.12 \\
\hline $\mathrm{Ni}(\%)$ & $<0.05$ & $<0.05$ & $<0.05$ & 0.07 \\
\hline $\mathrm{Si}(\%)$ & 15.9 & 10.8 & 15.7 & 9.73 \\
\hline $\mathrm{Ce}(\%)$ & 0.92 & 0.33 & 0.92 & 0.32 \\
\hline Cs (ppm) & 6.2 & 2.1 & $<1.0$ & $<1.0$ \\
\hline $\mathrm{La}(\%)$ & 0.74 & 0.22 & 0.73 & 0.21 \\
\hline $\mathrm{Nd}(\%)$ & 0.81 & 0.31 & 0.82 & 0.30 \\
\hline $\mathrm{Sr}$ & $0.35 \%$ & $800 \mathrm{ppm}$ & $0.34 \%$ & $600 \mathrm{ppm}$ \\
\hline \multicolumn{5}{|c|}{$\begin{array}{l}\%=\text { Weight percent } \\
\text { ppm }=\text { Parts Per Million }\end{array}$} \\
\hline \multicolumn{5}{|c|}{$\begin{array}{l}\text { Sample Identification: S52694H-Borate; slag from hearth } \\
\text { S52694I-Borate; slag from ingot }\end{array}$} \\
\hline $\begin{array}{l}\text { The cumulative } \\
\text { weighed } 1832 \text { a }\end{array}$ & $\begin{array}{l}\text { cted from } \\
\text { grams, resp }\end{array}$ & ct ingot us & rate flux a & ite flux \\
\hline
\end{tabular}


Comments concerning the test results are presented below:

- $\quad$ The $\mathrm{Al}, \mathrm{Ca}, \mathrm{Ce}, \mathrm{La}, \mathrm{Nd}, \mathrm{Si}$, and $\mathrm{Sr}$ concentrations for both fluxes were significantly higher for the hearth slags than for the crucible slags.

- $\quad \mathrm{The} \mathrm{Cr}, \mathrm{Fe}, \mathrm{Mn}$, and $\mathrm{Nb}$ concentrations for both fluxes were significantly higher for the crucible slags than for the hearth slags.

- The surrogate concentrations in the slag were independent of the oxidizing power of the fluxes. The surrogate concentrations in the slag from the First Controlled Oxidation Tests were almost double the concentrations in the slags from the Second Controlled Oxidation Tests. These lower concentrations are the result of lower surrogate concentrations in the starting metal and larger amounts of flux present in the second test.

- Chromium and Mn contents for the crucible slags were much higher than the contents for the hearth slags; probably because of the longer soaking times in the ingot crucible.

\subsection{DISTRIBUTION RATIO}

Distribution ratios are presented in Table 4.6 for the Second Controlled Oxidation Melts. The distribution values are significantly lower than those reported in Table 4.3, even though the oxidizing conditions for the borate and ferrite fluxes were greater than those in the previous test. This may be because the two product ingots from the first controlled oxidation melt were used as starting material for the second controlled oxidation test. Also, a greater mass of flux was added in this test (5\%) compared to the first test $(2 \%)$.

\section{TABLE 4.6. DISTRIBUTION RATIOS FOR THE SECOND CONTROLLED OXIDATION MELT}

\begin{tabular}{|c|c|c|c|c|c|c|}
\hline SAMPLE & $\begin{array}{c}\text { FLUX } \\
\text { TYPE }\end{array}$ & Ce & La & Nd & Cs & Sr \\
\hline M52694T & Borate & 110 & 116 & 129 & N.A. & 92 \\
\hline M52794T & Ferrite & 145 & 150 & 214 & N.A. & 133 \\
\hline N.A.: Not Available
\end{tabular}

\subsubsection{CONTROLLED OXIDATION MELT: $2 \% \mathrm{O}_{2}$}

A third pilot scale surrogate removal test was performed at RETECH. This test was designed to investigate the use oxygen as the oxidant. Flux was not used. Two percent $\mathrm{O}_{2}$ was injected on the 
surface of the hearth metal through the plasma torch, i.e., the injection gas contained $2 \%$ oxygen, $98 \%$ helium.

\subsection{INITIAL CONDITIONS FOR MELT: $2 \% \mathrm{O}_{2}$ EXPERIMENT}

Two ingots of approximately 114 kilograms each were melted under injected $\mathrm{O}_{2}$. The metal feed rate was held approximately constant at 28 centimeters/hour for the first half of the melt and at 15-20 centimeters/hour for the second half of the melt. The feedstock utilized was master alloy ingots.

\subsection{TEST RESULTS}

The results from the $2 \% \mathrm{O}_{2}$ controlled oxidation melt test work verified that surrogate removal via $\mathrm{O}_{2}$ is more effective than by use of an oxidizing flux. The metal and slag analyses are presented in Tables 4.7 and 4.8 .

\subsection{METAL ANALYSES}

Metal phase surrogate concentrations show that the final surrogate concentrations were not lowered to the levels achieved by induction melting in air. The expected result that slower feed rate should result in lower surrogate concentrations was achieved. The metal phase analyses are presented in Table 4.7 .

\section{TABLE 4.7. METAL PHASE ANALYTICAL RESULTS FOR THE $2 \% \mathrm{O}_{2}$ CONTROLLED OXIDATION MELT}

\begin{tabular}{|c|c|c|c|c|}
\hline \multirow[b]{3}{*}{ ELEMENT } & \multicolumn{4}{|c|}{ SAMPLE ANALYZED } \\
\hline & \multicolumn{2}{|c|}{$\begin{array}{c}\text { MELT RATE } \\
\text { (28 CENTIMETERS/HOUR) }\end{array}$} & \multicolumn{2}{|c|}{$\begin{array}{c}\text { MELT RATE } \\
\text { (15-20 CENTIMETERS/HOUR) }\end{array}$} \\
\hline & $\begin{array}{l}\text { M72094-1 } \\
\text { TOP OF } \\
\text { INGOT } \\
\end{array}$ & $\begin{array}{c}\text { M72094-4 } \\
\text { BOTTOM OF } \\
\text { INGOT }\end{array}$ & $\begin{array}{c}\text { M72094-3 } \\
\text { BOTTOM OF } \\
\text { INGOT } \\
\end{array}$ & $\begin{array}{l}\text { M72094-2 } \\
\text { TOP OF } \\
\text { INGOT }\end{array}$ \\
\hline $\mathrm{Al}(\%)$ & $<0.01$ & $<0.01$ & $<0.01$ & $<0.01$ \\
\hline $\mathrm{B}(\%)$ & $\leq 0.01$ & $<0.01$ & $<0.01$ & $<0.01$ \\
\hline $\mathrm{Ca}(\%)$ & $<0.01$ & $<0.01$ & $<0.01$ & $<0.01$ \\
\hline $\mathrm{Cr}(\%)$ & 18.4 & 18.3 & 18.3 & 18.2 \\
\hline $\mathrm{Fe}(\%)$ & 69.0 & 69.0 & 69.1 & 69.1 \\
\hline $\operatorname{Mn}(\%)$ & 1.40 & 1.51 & 1.33 & 1.44 \\
\hline $\mathrm{Si}(\%)$ & 0.18 & 0.23 & 0.22 & 0.23 \\
\hline
\end{tabular}




\begin{tabular}{|c|c|c|c|c|}
\hline \multirow[b]{3}{*}{ ELEMENT } & \multicolumn{4}{|c|}{ SAMPLE ANALYZED } \\
\hline & \multicolumn{2}{|c|}{$\begin{array}{c}\text { MELT RATE } \\
\text { (28 CENTIMETERS/HOUR) } \\
\end{array}$} & \multicolumn{2}{|c|}{$\begin{array}{c}\text { MELT RATE } \\
\text { (15-20 CENTIMETERS/HOUR) }\end{array}$} \\
\hline & $\begin{array}{l}\text { M72094-1 } \\
\text { TOP OF } \\
\text { INGOT }\end{array}$ & $\begin{array}{c}\text { M72094-4 } \\
\text { BOTTOM OF } \\
\text { INGOT }\end{array}$ & $\begin{array}{c}\text { M72094-3 } \\
\text { BOTTOM OF } \\
\text { INGOT }\end{array}$ & $\begin{array}{l}\text { M72094-2 } \\
\text { TOP OF } \\
\text { INGOT }\end{array}$ \\
\hline Cs (ppm) & $<1.0$ & $<1.0$ & $<1.0$ & $<1.0$ \\
\hline $\mathrm{La}(\mathrm{ppm})$ & 290 & 51 & 18 & 6.3 \\
\hline $\mathrm{Nd}(\mathrm{ppm})$ & 280 & 92 & 23 & 6.2 \\
\hline
\end{tabular}

Comments concerning the test results are presented below:

- $\quad$ For the melt rate at $28 \mathrm{~cm} / \mathrm{hr}$ the surrogate $(\mathrm{Ce}, \mathrm{La}$, and $\mathrm{Nd})$ concentrations varied from 51 to $290 \mathrm{ppm}$; while, the surrogate concentrations for the $15-20 \mathrm{~cm} / \mathrm{hr}$ melt rate varied from 6.2 to $33 \mathrm{ppm}$.

- For the melt rate of $28 \mathrm{~cm} / \mathrm{hr}$ the surrogate removal by gaseous oxygen was less than the flux controlled oxidation melts (which was conducted at approximately $20 \mathrm{~cm} / \mathrm{hr}$, Table 4.4). For the melt rate of $15-20 \mathrm{~cm} / \mathrm{hr}$ the surrogate removal by gaseous oxygen was approximately the same when compared to the flux controlled oxidation melts at the same rate (Table 4.4.).

- Chromium and Mn were only slightly decreased for both feed rates.

\subsection{SLAG ANALYSES}

Only one slag sample was sent for analysis, i.e., the final slag present at the end of the test period. The slag analytical data are presented in Table 4.8

TABLE 4.8. SLAG ANALYSES FOR $2 \% \mathrm{O}_{2}$ CONTROLLED OXIDATION MELT

\begin{tabular}{|c|c|c|c|c|c|c|c|c|}
\hline \multirow{2}{*}{$\begin{array}{c}\text { SLAG } \\
\text { SAMPLE }\end{array}$} & \multicolumn{8}{|c|}{ ELEMENTS ANALYZED } \\
\hline & $\begin{array}{c}\mathrm{Al} \\
(\%)\end{array}$ & $\begin{array}{l}\mathbf{C r} \\
(\%)\end{array}$ & $\begin{array}{c}\mathrm{Fe} \\
(\%)\end{array}$ & $\begin{array}{l}\text { Mn } \\
(\%)\end{array}$ & $\begin{array}{c}\mathbf{S i} \\
(\%)\end{array}$ & $\begin{array}{c}\mathrm{Ce} \\
(\mathbf{p p m})\end{array}$ & $\begin{array}{c}\mathbf{L a} \\
(\mathbf{p p m})\end{array}$ & $\begin{array}{c}\text { Nd } \\
(\mathbf{p p m})\end{array}$ \\
\hline S11994-2* & 0.4 & 11.1 & 4.4 & 11.0 & 7.8 & 180 & 170 & 950 \\
\hline
\end{tabular}




\subsection{DISTRIBUTION RATIO}

Distribution ratios are presented in Table 4.9 for the $2 \% \mathrm{O}_{2}$ controlled oxidation melt.

TABLE 4.9. DISTRIBUTION RATIO FOR THE $2 \% \mathrm{O}_{2}$ CONTROLLED OXIDATION MELT

\begin{tabular}{|c|c|c|c|c|c|}
\hline Sample & Ce & La & Nd & Cs & Sr \\
\hline M72094-2 & 20 & 27 & 153 & N.A. & N.A. \\
\hline N.A.-Not available \\
\hline
\end{tabular}

\subsubsection{CONTROLLED OXIDATION MELT: $5 \% \mathrm{O}_{2}$ \\ 4.1.2.5.1. INITIAL CONDITIONS FOR MELT: 5\% O2 EXPERIMENT}

Another controlled oxidation test consisted of increasing the injected $\mathrm{O}_{2}$ content from $2 \%$ to $5 \%$. The feedstock was the ingot product from the $2 \% \mathrm{O}_{2}$ melt. The melt rate was held at 20 centimeters per hour for one half of the melt time but was then increased to 41 centimeters per hour for the remaining half of the experiment.

\subsection{TEST RESULTS}

The increase in the oxygen feed rate caused a notable difference in the final ingot surrogate concentrations, especially cerium. Only cerium, lanthanum and neodymium were analyzed in the metal phase (since the other elemental concentrations in the metal phase for previous melts did not appear to be effected by the oxidizing action of $\mathrm{O}_{2}$ ). Analytical results for the metal and slag products are presented in Tables 4.10 and 4.11 , respectively.

\subsection{METAL ANALYSES}

By increasing the $\mathrm{O}_{2}$ to $5 \%$ the final concentrations of the surrogates dropped significantly from the 2\% $\mathrm{O}_{2}$ test as shown in Table 4.10. The results however still did not achieve the decontamination levels achieved by induction melting in an air atmosphere (except for cerium). 
TABLE 4.10. METAL ANALYSES FROM $5 \% \mathrm{O}_{2}$ CONTROLLED OXIDATION MELT

\begin{tabular}{|c|c|c|c|c|c||}
\hline \multirow{3}{*}{ ELEMENT } & \multicolumn{5}{|c||}{ SAMPLE ANALYZED } \\
\cline { 2 - 6 } & \multicolumn{2}{|c|}{$\begin{array}{c}\text { MELT RATE } \\
\text { (41 CM/HOUR) }\end{array}$} & \multicolumn{3}{c||}{$\begin{array}{c}\text { MELT RATE } \\
\text { (20 CM/HOUR) }\end{array}$} \\
\cline { 2 - 6 } & $\begin{array}{c}\text { M9294-1 } \\
\text { TOP }\end{array}$ & $\begin{array}{c}\text { M9294-2 } \\
\text { BOTTOM }\end{array}$ & $\begin{array}{c}\text { M9294-3 } \\
\text { TOP }\end{array}$ & $\begin{array}{c}\text { M9294-4 } \\
\text { MIDDLE }\end{array}$ & $\begin{array}{c}\text { M9294-5 } \\
\text { BOTTOM }\end{array}$ \\
\hline Ce (ppm) & $<1.0$ & $<1.0$ & $<1.0$ & $<1.0$ & $<1.0$ \\
\hline La (ppm) & 7.4 & 22 & $<1.0$ & 1.8 & 33 \\
\hline Nd (ppm) & 11 & 28 & 1.2 & 2.8 & 78 \\
\hline (ppm) = Parts Per Million & & & & \\
\hline
\end{tabular}

Comments concerning the test results are presented below:

- As anticipated the surrogate concentrations for the $20 \mathrm{~cm} / \mathrm{hr}$ melt rate are lower than for the $41 \mathrm{~cm} / \mathrm{hr}$ except for sample M9294-5 which may have contained a slag inclusion in the metal sample.

- The difference between the Ce concentration levels and $\mathrm{La}, \mathrm{Nd}$ concentration levels is unusual since $\mathrm{Ce}$ is the least stable oxide of the three surrogates.

\subsection{SLAG ANALYSES}

Since the metal analyses for this pilot scale test melt were above $1.0 \mathrm{ppm}$ for the surrogate concentrations only one slag sample was analyzed. The slag sample is a combination of the hearth slag from both the melt rate tests.

\section{TABLE 4.11. SLAG ANALYSES FOR $5 \% \mathrm{O}_{2}$ CONTROLLED OXIDATION MELT}

\begin{tabular}{||c|c|c|c|c|c|c|c|c||}
\hline \multirow{2}{*}{$\begin{array}{c}\text { SLAG } \\
\text { SAMPLE }\end{array}$} & $\begin{array}{c}\text { Al } \\
(\%)\end{array}$ & $\begin{array}{c}\mathbf{C r} \\
(\%)\end{array}$ & $\begin{array}{c}\mathbf{F e} \\
(\%)\end{array}$ & $\begin{array}{c}\mathbf{M n} \\
(\%)\end{array}$ & $\begin{array}{c}\mathbf{S i} \\
(\%)\end{array}$ & $\begin{array}{c}\mathbf{C e} \\
(\mathbf{p p m})\end{array}$ & $\begin{array}{c}\text { La } \\
(\mathbf{p p m})\end{array}$ & $\begin{array}{c}\text { Nd } \\
(\mathbf{p p m})\end{array}$ \\
\hline S11994-3* & 0.4 & 10.5 & 9.6 & 7.6 & 6.5 & 180 & 160 & 920 \\
\hline$*$ \\
The slag sample is a combination of the ingot slag from both melt rate tests. \\
The total combined slag collected for the ingot using 5\% $\mathrm{O}_{2}$ weighed 227 grams. \\
\hline
\end{tabular}




\subsection{DISTRIBUTION RATIO}

The distribution ratio for the $5 \% \mathrm{O}_{2}$ are presented in Table 4.12 .

\section{TABLE 4.12. DISTRIBUTION RATIO FOR THE $5 \% \mathrm{O}_{2}$ CONTROLLED OXIDATION MELT}

\begin{tabular}{|c|c|c|c|c|c|}
\hline Sample & $\mathrm{Ce}$ & La & Nd & Cs & Sr \\
\hline M9294-1 & $>180$ & 22 & 84 & N.A. & N.A. \\
\hline \multicolumn{6}{|c|}{ N.A.-Not available } \\
\hline \multicolumn{6}{|c|}{ M9294-1 is a metal sample selected at the $20 \mathrm{~cm} / \mathrm{hr}$ melt rate. } \\
\hline
\end{tabular}

\subsubsection{CONTROLLED OXIDATION MELT: $5 \%$ AND $10 \% \mathrm{O}_{2}$ (WITH A REFRACTORY LINING)}

\subsection{INITIAL CONDITIONS FOR MELT: 5 AND $10 \% \mathrm{O}_{2}$ EXPERIMENT}

The fifth pilot scale controlled oxidation melt consisted of injecting $5 \%$ (for half the test period) and $10 \% \mathrm{O}_{2}$ (for half the test period) across the hearth from an auxiliary port instead of injecting the $\mathrm{O}_{2}$ through the plasma torches. The cold hearth was lined with the same chromia-alumina refractory that was used in the Montana Tech induction furnace. This refractory was rammed to fit the crucible but was not sintered. The refractory was installed so that superheating could be achieved in the molten pool; therefore, mimicking the superheating conditions achieved in the experimental induction tests. A new master surrogate ingot was used for this melt, weighing 114 kilograms. The master ingot contained approximately 400 to $500 \mathrm{ppm}$ of $\mathrm{La}, \mathrm{Ce}$, and $\mathrm{Nd}$. The metal feed rate was approximately 20 centimeters/hour.

\subsection{TEST RESULTS}

The results from this experiment were significantly different than what was anticipated. Surrogate concentrations in the resulting ingot varied over the range from 67 to $210 \mathrm{ppm}$. The analytical results for both of the metal and slag are presented in Tables 4.11 and 4.12, respectively.

\subsection{METAL ANALYSES}

The metal phase was analyzed only for the surrogate elements. The unanticipated results presented in Table 4.13 suggest that the attempt to provide superheating in the hearth metal was not successful. 
The reason that surrogate concentrations are so high when the oxidation conditions appear to be appreciable is yet unknown.

TABLE 4.13. METAL PHASE ANALYSES FOR 5 AND $10 \% \mathrm{O}_{2}$ WITH REFRACTORY CONTROLLED OXIDATION MELT

\begin{tabular}{|c|c|c|}
\hline \multirow{3}{*}{ ELEMENT } & \multicolumn{2}{|c|}{ SAMPLE ANALYZED } \\
\hline & $\begin{array}{c}10 \% \mathrm{O}_{2} \mathrm{AT} \\
20 \mathrm{CM} / \mathrm{HOUR} \\
\end{array}$ & $\begin{array}{c}5 \% \mathrm{O}_{2} \mathrm{AT} \\
20 \mathrm{CM} / \mathrm{HOUR}\end{array}$ \\
\hline & M102494-1 & M102494-2 \\
\hline $\mathrm{Ce}(\mathrm{ppm})$ & 75 & 130 \\
\hline $\mathrm{La}(\mathrm{ppm})$ & 67 & 210 \\
\hline $\mathrm{Nd}(\mathrm{ppm})$ & 79 & 210 \\
\hline
\end{tabular}

Comments concerning the test results are presented below:

- A chromia-alumina refractory hearth liner was used to allow superheat in the molten metal in the hearth, but the refining effectiveness of this modification did not increase the effectiveness of surrogate removal.

- The 5 and $10 \% \mathrm{O}_{2}$ that was injected across the hearth from an auxiliary port instead of the $\mathrm{O}_{2}$ through the plasma torches may have been a less effective way to supply oxygen for the decontamination reactions.

\subsection{SLAG ANALYSES}

The slag phase analyses are presented in Table 4.14 for both the hearth slag and the crucible slag. 
TABLE 4.14. SLAG ANALYSES FOR 5 AND $10 \% \mathrm{O}_{2}$ OXIDATION MELT WITH REFRACTORY

\begin{tabular}{|c|c|c|}
\hline \multirow[b]{2}{*}{ Elements } & \multicolumn{2}{|c|}{ Sample Analyzed } \\
\hline & $\begin{array}{c}5-10 \% \mathrm{O}_{2} \\
\text { Hearth Slag } \\
\text { S11994-6 }\end{array}$ & $\begin{array}{c}5-10 \% \mathrm{O}_{2} \\
\text { Crucible Slag } \\
\text { S11994-5 } \\
\end{array}$ \\
\hline $\mathrm{Al}(\%)$ & 0.5 & 0.30 \\
\hline $\mathrm{Cr}(\%)$ & 12.5 & 14.2 \\
\hline $\mathrm{Fe}(\%)$ & 10.7 & 9.8 \\
\hline $\operatorname{Mn}(\%)$ & 7.8 & 13.2 \\
\hline $\mathrm{Si}(\%)$ & 4.8 & 5.3 \\
\hline $\mathrm{Ce}$ (ppm) & 180 & 29000 \\
\hline $\mathrm{La}(\mathrm{ppm})$ & 160 & 28000 \\
\hline $\mathrm{Nd}(\mathrm{ppm})$ & 940 & 32000 \\
\hline \multicolumn{3}{|c|}{$\begin{array}{l}\%=\text { Weight Percent } \\
\text { ppm }=\text { Parts Per Million }\end{array}$} \\
\hline
\end{tabular}

\subsection{DISTRIBUTION RATIO}

Distribution ratios are presented in Table 4.15 for the $5-10 \% \% \mathrm{O}_{2}$ controlled oxidation melt.

\section{TABLE 4.15. DISTRIBUTION RATIO TABLE FOR THE 5 AND $10 \% \mathrm{O}_{2}$} CONTROLLED OXIDATION MELT

\begin{tabular}{|c|c|c|c|c|c|}
\hline Sample & $\mathrm{Ce}$ & La & Nd & Cs & $\mathbf{S r}$ \\
\hline M102494-1 & 2.4 & 2.4 & 12 & N.A. & N.A. \\
\hline \multicolumn{6}{|c|}{ N.A.-Not available } \\
\hline \multicolumn{6}{|c|}{ M9294-1 is a metal sample selected at the 20 centimeters/hour melt rate with $10 \% \mathrm{O}_{2}$} \\
\hline \multicolumn{6}{|c|}{ The slag data used to generate the distribution ratio values is a composite slag from both oxygen melts. } \\
\hline
\end{tabular}




\subsubsection{CONTROLLED OXIDATION MELT: $10 \% \mathrm{O}_{2}$}

\subsection{INITIAL CONDITIONS FOR MELT/10\% $\mathrm{O}_{2}$}

A final controlled oxidation melt was performed at RETECH which consisted of injecting $10 \% \mathrm{O}_{2}$ through the plasma torch. Argon was used as the inert gas instead of helium. The ingot resulting from the previous test (Section 4.6) was remelted as the feedstock for this test. The feedrate was approximately 20 centimeters/hour.

\subsection{TEST RESULTS}

Results from the controlled oxidation melt have provided surrogate concentration results that are similar to the open atmosphere induction results. Several samples were taken from the test products for analysis, i.e., the ingot, the top of the skull, and the bottom of the skull. Analytical results for the metal and slag are presented in Tables $4.15^{\circ}$ and 4.16 , respectively.

\subsection{METAL ANALYSES}

Analysis of the metal phase revealed that effective surrogate oxidation had occurred. The metal analyses results are presented in Table 4.16 .

Original analytical results for the product ingot showed a rather high surrogate concentration. The sample presumably had a slag inclusion present. This was believed to be the case because of the low surrogate concentrations in the skull top. Resampling of the ingot (samples M1695-D and M1695-E) confirmed that the sample was contaminated. The analysis of the hearth skull bottom are presented to demonstrate the difference in surrogate concentration across the skull thickness.

\section{TABLE 4.16. METAL PHASE ANALYSES FOR 10\% $\mathrm{O}_{2}$ CONTROLLED OXIDATION MELT}

\begin{tabular}{|c|c|c|c|c|c|}
\hline \multirow{3}{*}{ ELEMENT } & \multicolumn{5}{|c|}{ SAMPLE ANALYZED } \\
\hline & \multicolumn{5}{|c|}{ MELT RATE OF 20 CENTIMETERS/HOUR } \\
\hline & $\begin{array}{l}\text { INGOT } \\
\text { SAMPLE } \\
\text { M1695-A }\end{array}$ & $\begin{array}{l}\text { INGOT } \\
\text { SAMPLE } \\
\text { M1695-D } \\
\end{array}$ & $\begin{array}{c}\text { INGOT } \\
\text { SAMPLE } \\
\text { M1695-E }^{1} \\
\end{array}$ & $\begin{array}{c}\text { SKULL } \\
\text { TOP } \\
\text { M1695-B }\end{array}$ & $\begin{array}{c}\text { SKULL } \\
\text { BOTTOM } \\
\text { M1695-C } \\
\end{array}$ \\
\hline $\mathrm{Ce}(\mathrm{ppm})$ & 73 & $<1.0$ & $<1.0$ & 1.0 & 57 \\
\hline $\mathrm{La}(\mathrm{ppm})$ & 64 & $<1.0$ & $<1.0$ & $<1.0$ & 65 \\
\hline $\mathrm{Nd}(\mathrm{ppm})$ & 80 & $<1.0$ & $<1.0$ & $<1.0$ & 54 \\
\hline \multicolumn{6}{|c|}{$\begin{array}{l}\text { Samples M1695-D and M1695-E were resamples taken from the center and the outside of the ingot } \\
\text { after the ingot was cut axially in half to verify that there were slag inclusions in samples M1695-A and } \\
\text { M1695-C. }\end{array}$} \\
\hline
\end{tabular}

Comments concerning the test results are presented below: 
- The $10 \% \mathrm{O}_{2}$ at a 20 centimeters/hour melt rate has demonstrated decontamination of stainless steel to $<1.0 \mathrm{ppm}$.

- The test has also demonstrated that supply of oxygen through the torch is much more effective than suppling it over the hearth surface.

\subsection{SLAG ANALYSES}

Slag analyses were not collected for this test.

\subsubsection{VACUUM INDUCTION MELT PROGRAM}

\subsubsection{GOALS OF THE VIM PROGRAM}

The goals for the vacuum induction melt (VIM) program included: effective removal of surrogates (to $<1 \mathrm{ppm}$ ), and decarburization of the metallic solution to less than $300 \mathrm{ppm}$ carbon by vacuum treatment in the presence of controlled quantities of air, carbon dioxide, or solid oxide. The desire was to selectively remove the surrogates and carbon without appreciable loss of chromium (which occurs when induction melting is conducted in air at ambient pressure). The authors sought to demonstrate that the goals could be met in a single step in reasonable time without the complications involved using bottom tapping or bottom blowing.

A series of eight VIM melts were performed in environments that contained different levels of oxidizing powers. The individual experimental conditions and test results are described in Section 4.1.3.3.

\subsubsection{DESCRIPTION OF THE MELT FACILITY}

The melting facility used for the vacuum induction experiments is located at the Retech, Inc. Manufacturing plant near Ukiah, California. The furnace consists of a water cooled coreless induction coil, power supply, vacuum chamber, and associated hardware.

An overall view of the VIM facility used for this work is presented in Figure 4.2. The induction coil is mounted to the door of the vacuum chamber, allowing easy access to the coil and the mold section of the chamber during loading, unloading, and cleaning, Figure 4.3. The power leads carry the cooling water to the coil through the coil tilt mechanism on the chamber door. A hydraulic motor is used to rotate the coil (crucible) clockwise and counter clockwise about the vertical position for casting. Samples were taken at intermediate times by rotating the crucible counter clockwise to pour molten metal into a prepositioned crucible (i.e., a crucible located on the side of the furnace chamber opposite the final melt mold).

The coil box, 18.5 by 18.5 by 22 inches high houses a ten-turn coil 14.5 inches inside diameter by 15 inches high. Allied Mineral Star Ram 313 was used to mud (cover) the coils for the first crucible 
fabricated while Minro Al A91 plastic was used to mud the coil for the second crucible used. Crucibles (inside the coil) were rammed (using Minro Al A52 dry ramming mix) into a steel tubing form. In-situ sintering of the refractory was accomplished in a conventional manner by melting and holding approximately 250 pounds of steel at $1600^{\circ} \mathrm{C}$ for one hour prior to casting. During the melting campaigns no measurable erosion of the 10.5-inch diameter by 14-inch high crucible was observed. Some crucible damage was inflicted during removal of adhered metal splatter from the upper sections of the crucible. Broken sections were successfully patched with A91 plastic.

An Ajax Phasor AC/DC Solid State Model \#3-84 power supply converts 480 volt three phase to a single phase maximum output of 125 kilowatts, 400 volts, 4500 amps at 3,000 hertz. Load mismatch limited power to approximately $80 \%$.

The induction furnace sits within a chamber that is 40 -inches deep, 64 -inches wide by 83 -inches high. The vacuum chamber is water cooled and is evacuated by a Rootes blower backed by a 250 cfm Stokes mechanical pump. Mechanical and thermocouple gages provide vacuum measurements. The bottom of the coil is 48 inches above the floor and 13 inches from the door. Two view ports provide visual reference from the control deck located at the rear and top of the chamber. One view port allows the melt crucible to be observed while the second allows observation of the funnel during the pour. An alloy feeding system, consisting of six alloy hoppers and a retractable chute, provides for the addition of six different alloys during the melt without power or vacuum interruption. Process gases are introduced through a lance above the crucible or through several other ports in the furnace body.

Temperature measurements were taken with a two-color optical pyrometer and Type $\mathrm{K}$ thermocouples. Initial pyrometer calibration was confirmed with a Type $\mathrm{R}$ thermocouple. The thermal arrest observed during melting of the charge provided additional verification of the pyrometer. 


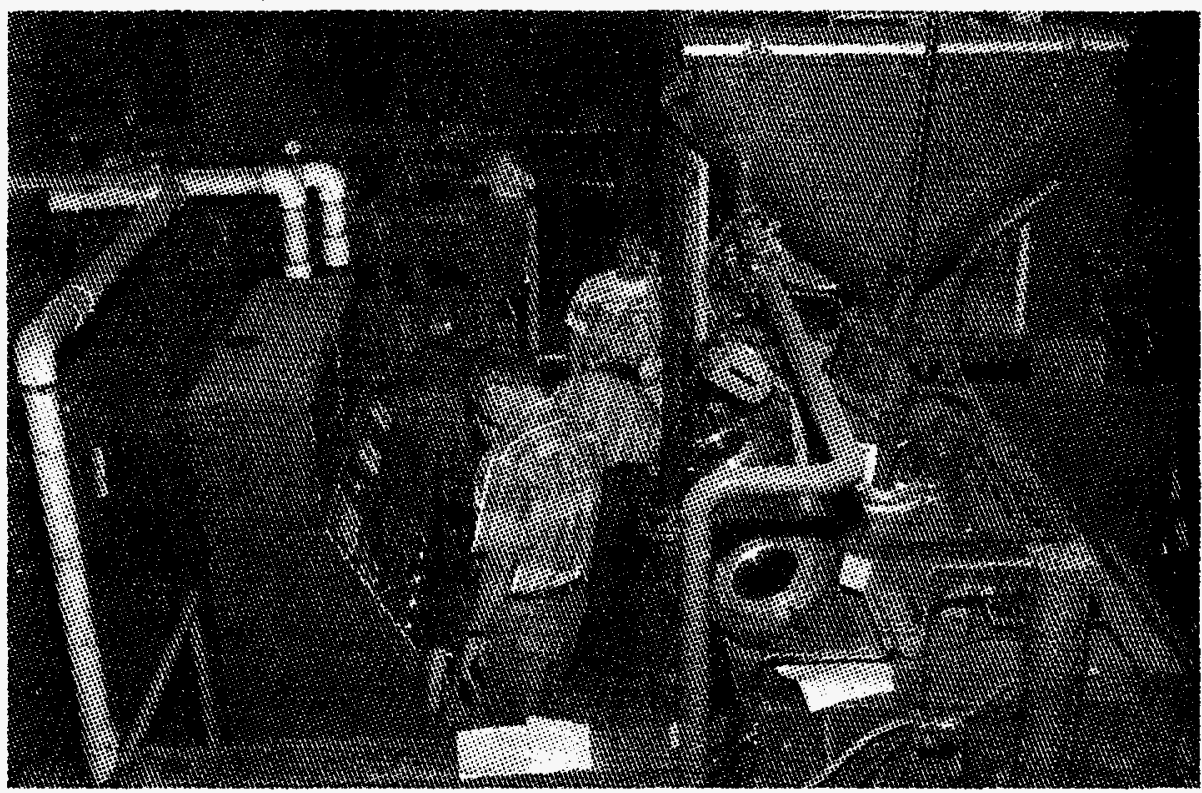

Figure 4.2 Overhead View of the Retech $125 \mathrm{KW}$ VIM Showing Operator Console, View Ports. Gas Lance. and Allov Feeder

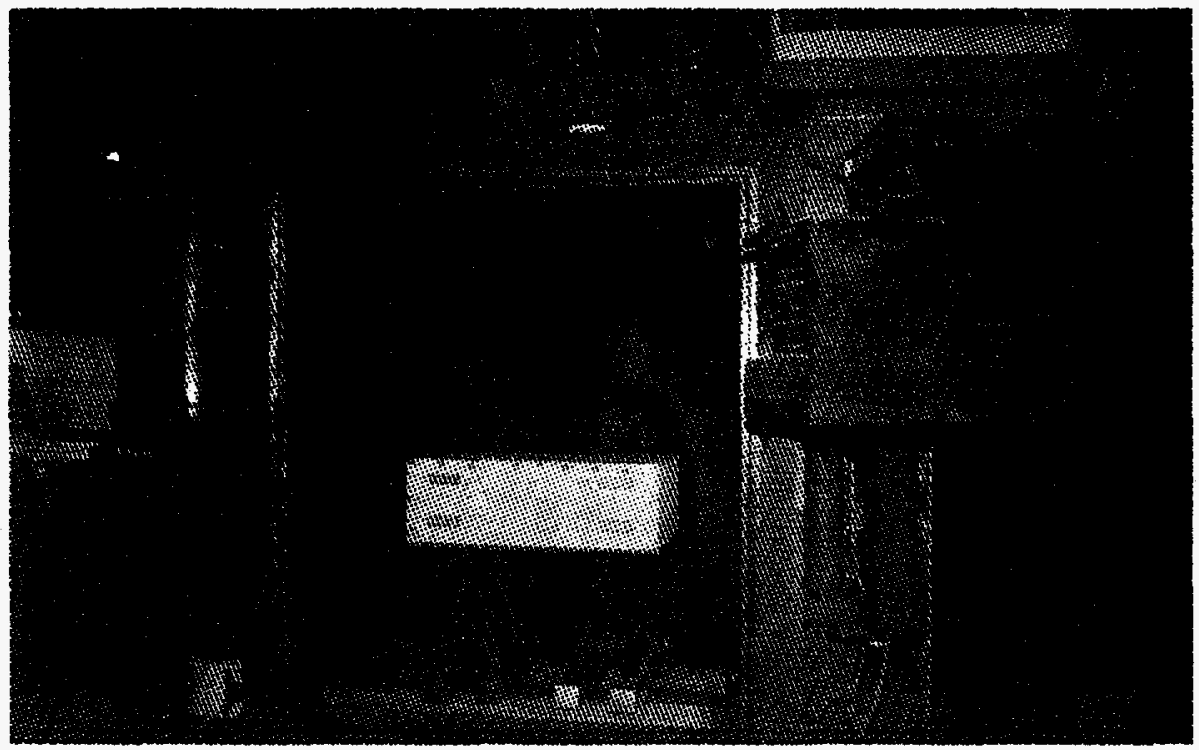

Figure 4.3 The Retech VIM with the Door Open and a Mold Box in Place. 


\subsubsection{TEST MELTS}

All tests were conducted at a nominal temperature of $1600^{\circ} \mathrm{C}$. The temperature was maintained manually by controlling the power input into the molten metal. Temperature was monitored using an IRCON two-color pyrometer. Time zero was taken to be when the melt temperature first reached $1600^{\circ} \mathrm{C}$. The experimental tests conducted are listed below: (The experimental procedure is presented in Section 4.1.3.4.; the experimental conditions and experimental results are presented and discussed in Sections 4.1.3.5.1-4.1.3.5.2.)

- VIM 1: Vacuum Melting at One Torr for 0.5 Hour at Temperature.

- VIM 2: Vacuum Melting at a Carbon Dioxide Pressure of 75 Torr: Carbon Dioxide Blown into Chamber During Heat up and for 0.5 Hour at Temperature.

- VIM 3: Vacuum Melting at a Carbon Dioxide Pressure of 75 Torr: Carbon Dioxide Blown into Chamber During Heat up and Then Onto the Molten Surface for 0.5 Hour at Temperature.

- VIM 4: Vacuum Melting at 75 Torr Pressure of Air During Heat up. Carbon Dioxide Blown onto Molten Surface at Test Temperature for 1.0 Hour While Maintaining 75 Torr Pressure.

- VIM 5: Vacuum Melting at 50 Torr (Air) with Air Blown onto the Molten Surface for 1.0 Hour While Maintaining 50 Torr.

- VIM 6: Vacuum Melting ( $<2$ Torr) for 1.0 Hours at Temperature with the Addition of 0.25 -Pounds of Magnetite at Time Zero.

- VIM 7: Vacuum Melting ( $<2$ Torr) for 1.0 Hours with the Addition of 1.0 Pound of Magnetite at Time Zero and 1.0 Pound at Thirty Minutes.

- VIM 8: Vacuum Melting ( $<2$ Torr) for 1.5 Hours with the Addition of 1.0 Pound of Magnetite at Time Zero and 1.0 Pound at Each of Three 25 Minute Intervals.

\subsubsection{TEST PROCEDURE}

The experimental procedure consisted of placing approximately 250 pounds of stainless steel surrogate master melt ingot into a rammed alumina crucible. Sand molds were positioned in the furnace housing so that casting could be accomplished under a vacuum. The system was closed and a vacuum pulled on the chamber before power was applied. The desired conditions (type of gas, mass flow of gas, addition of magnetite) were established in the system either prior to ingot melting or subsequent to ingot melting. After the desired test exposures were completed the metal was poured under vacuum in the pre-positioned sheet-bar mold. The metal was allowed to 
cool (usually overnight) before breakout. The metal was removed from the mold and sampled at various positions for determination of surrogate and carbon concentrations. A detailed description of each test is presented in Section 4.1.3.5.

\subsubsection{TEST RESULTS}

The results of this series of tests are presented in the following sections;

4.1.3.5.1. Baseline Data: Vacuum Exposure

4.1.3.5.2. Gas Oxidizers: Carbon Dioxide or Air

4.1.3.5.3. Solid Oxidizer: Magnetite

\subsection{BASELINE DATA: VACUUM EXPOSURE}

\section{VIM 1}

Approximately 270 pounds of stainless steel master melt ingot was melted in the vacuum induction furnace, without the addition of any oxidizing species, to provide background data for the VIM series of tests. The conditions and experimental results are presented in Table 4.17.

Note that surrogates were removed to below one part per million but that carbon was unaffected.

Most of the VIM tests were modeled using the CSIRO Thermochemistry calculational software. The input elements and their concentrations are listed in column four, Table 4.17. The calculational program assumptions included the following: temperature $=1600^{\circ} \mathrm{C}$; pressure as measured during the test; the reference state for all slag constituents was the dissolved oxide constituents in the liquid state; reference state for the molten metal constituents was the dissolved elemental species; activity coefficients for slag constituents were assumed to be one; the Lupis solution model was used to describe the interaction coefficients in the molten metal; interaction coefficients for all species were taken from Lupis (Lupis, 1983) except for the rare earth surrogate elements; the temperature dependence of the infinitely dilute solution activity coefficients for the surrogate elements were assumed to be equivalent to that of aluminum; and the interaction coefficients for the surrogate elements were assumed to be equivalent to aluminum.

Note (Table 4.17) that the calculated surrogate concentrations show essentially no surrogate removal for the metallic phase, whereas, the measured surrogate concentrations in the metallic phase were all less than $1 \mathrm{ppm}$. This results indicates that there was an oxygen source in the system, i.e., probably surface oxidation products were present on the input ingot. The calculated carbon content is the same as the input carbon content and is essentially the same as the measured value showing that the oxygen source was not sufficient to decarburize the steel bath. 
TABLE 4.17. VIM 1: VACUUM INDUCTION MELTING OF STAINLESS STEEL

\begin{tabular}{|c|c|c|c|c|c|c|}
\hline \multicolumn{7}{|c|}{$\begin{array}{l}\text { VIM } 1 \\
\text { CONDITIONS: }\end{array}$} \\
\hline \multicolumn{7}{|c|}{$\begin{array}{l}\text { Date: } 5 / 23 / 95 \\
\text { Temp: } 1600-1650 \mathrm{C} \\
\text { Atm: Vacuum } \\
\text { Pressure: }<2 \text { Torr } \\
\text { Ingot: } 269.5 \text { Pounds } \\
\text { Time at Temperature: } 0.5 \text { Hour }\end{array}$} \\
\hline \multicolumn{7}{|l|}{ RESULTS: } \\
\hline ELEMENT & INGOT, $\%$ & IN & IN & IN & OUT & CALC \\
\hline & WT\% & LBS & GMS & PPM & PPM* & ppm \\
\hline $\mathrm{C}$ & 0.04 & 0.10 & 43.31 & 353 & 337 & 353 \\
\hline $\mathrm{Fe}$ & 70.09 & 188.90 & 85760.49 & 700927 & - & 699500 \\
\hline $\mathrm{Cr}$ & 17.80 & 47.97 & 21778.83 & 178000 & 182000 & 177700 \\
\hline $\mathrm{Ni}$ & 10.50 & 28.30 & 12847.07 & 105000 & - & 104800 \\
\hline $\mathrm{Si}$ & 0.29 & 0.78 & 354.82 & 2900 & 3000 & 2894 \\
\hline $\mathrm{Mn}$ & 1.28 & 3.45 & 1566.12 & 128000 & 11200 & 12800 \\
\hline $\mathrm{Ce}, \mathrm{ppm}$ & 677.00 & 0.18 & 82.83 & 677 & $<1$ & 675 \\
\hline $\mathrm{La}, \mathrm{ppm}$ & 740.00 & 0.20 & 90.54 & 740 & $<1$ & 738 \\
\hline $\mathrm{Nd}, \mathrm{ppm}$ & 507.00 & 0.14 & 62.03 & 507 & $<1$ & 506 \\
\hline
\end{tabular}

\subsection{GAS OXIDIZERS: CARBON DIOXIDE OR AIR}

\section{VIM 2, VIM 3, VIM 4, VIM 5}

Several tests were conducted to investigate surrogate removal and decarburization of stainless steel using gaseous oxidants, e.g., carbon dioxide (VIM 2, VIM 3, VIM 4) and air (VIM 5).

The VIM 2 test was performed by adding carbon dioxide to the vacuum chamber at a sufficient rate to maintain a pressure of approximately 50 torr. The test conditions and the experimental results are presented in Table 4.18 .

Note that surrogate removal was successful but that carbon removal was not effective. In fact, the carbon content increased in the product ingot. The reason for this was that carbon dioxide was blown into the chamber as the ingot steel was heating, i.e., carbide formation on the steel surface 
likely occurred during the heat-up stage and insufficient time (only one half hour) was allowed for the oxidation (by carbon dioxide) of the increased carbon content. Thermodynamic calculations confirm this possibility. It was later experimentally demonstrated that this was the case (See VIM 4 results).

TABLE 4.18. VIM 2: VACUUM INDUCTION MELTING OF STAINLESS STEEL IN THE PRESENCE OF CARBON DIOXIDE

\begin{tabular}{|c|c|c|c|c|c|}
\hline \multirow{2}{*}{\multicolumn{6}{|c|}{$\begin{array}{l}\text { CONDITIONS: } \\
\text { Date: } 8 / 8 / 95 \\
\text { Temp: } 1600-1650 \\
\text { Atm: Vacuum, CO2 (1.1 SCFM) Blown into Chamber } \\
\text { During Melting and for } 0.5 \text { Hrs While at Temperature } \\
\text { Pressure: } 50 \text { Torr } \\
\text { Ingot: } 257 \text { pounds } \\
\text { CO Input: } 2000 \text { grams } \\
\text { Time at Temperature: } 0.5 \text { Hours }\end{array}$}} \\
\hline & & & & & \\
\hline \multirow[t]{2}{*}{ ELEMENT } & INGOT & TOTAL & TOTAL & $\mathbf{I N}$ & OUT \\
\hline & WT\% & LBS & GMS & PPM & PPM* \\
\hline $\mathrm{C}$ & 0.0354 & 0.08 & 35.12 & 354 & 416 \\
\hline $\mathrm{Fe}$ & & 152.74 & 69342.28 & 699022 & - \\
\hline $\mathrm{Cr}$ & 17.8 & 38.89 & 17657.42 & 178000 & 180000 \\
\hline $\mathrm{Ni}$ & 10.5 & 22.94 & 10415.90 & 105000 & - \\
\hline $\mathrm{Si}$ & 0.29 & 0.63 & 287.68 & 2900 & 2800 \\
\hline $\mathrm{Mn}$ & 1.28 & 2.80 & 1269.75 & 12800 & 11800 \\
\hline $\mathrm{Ce}, \mathrm{ppm}$ & 677 & 0.15 & 67.16 & 677 & $<1$ \\
\hline $\mathrm{La}, \mathrm{ppm}$ & 740 & 0.16 & 73.41 & 740 & $<1$ \\
\hline $\mathrm{Nd}, \mathrm{ppm}$ & 507 & 0.11 & 50.29 & 507 & $<1$ \\
\hline
\end{tabular}

VIM 3 was conducted under essentially the same conditons as VIM 2 except the carbon dioxide was sparged onto the surface of the molten metal for approximately one-half hour. The results are presented in Table 4.19. Note that the results are similar to VIM 2, i.e. the surrogates were effectively removed but the carbon content increased. 
TABLE 4.19. VIM 3: VACUUM INDUCTION MELTING OF STAINLESS STEEL IN THE PRESENCE OF CARBON DIOXIDE

\begin{tabular}{|c|c|c|c|c|c|}
\hline \multirow{2}{*}{\multicolumn{6}{|c|}{$\begin{array}{l}\text { Date: } 8 / 9 / 95 \\
\text { Temp: } 1350-1600^{\circ} \mathrm{C} \text { (Test Aborted, Low Temp } \\
\text { Atm: Vacuum, CO2 (0.9 SCFM) Blown into C } \\
\text { Heat up }(1 \mathrm{Hr}) \text { and on Surface }(1.0 \mathrm{SCFM}) \text { for } \\
\text { Temperature } \\
\text { Pressure: } 55 \text { Torr } \\
\text { Ingot: } 257.5 \text { pounds } \\
\text { CO Input: } 5000 \text { grams } \\
\text { Time at Temperature: } 0.5 \text { Hour } \\
\text { RESULTS: }\end{array}$}} \\
\hline & & & & & \\
\hline \multirow[t]{2}{*}{ ELEMENT } & INGOT & TOTAL & TOTAL & IN & OUT \\
\hline & WT\% & LBS & GMS & PPM & PPM* \\
\hline C & 0.0354 & 0.08 & 35.12 & 354 & 426 \\
\hline $\mathrm{Fe}$ & & 152.74 & 69342.28 & 699022 & - \\
\hline $\mathrm{Cr}$ & 17.8 & 38.89 & 17657.42 & 178000 & 178000 \\
\hline $\mathrm{Ni}$ & 10.5 & 22.94 & 10415.90 & 105000 & - \\
\hline $\mathrm{Si}$ & 0.29 & 0.63 & 287.68 & 2900 & 3400 \\
\hline $\mathrm{Mn}$ & 1.28 & 2.80 & 1269.75 & 12800 & 12800 \\
\hline $\mathrm{Ce}, \mathrm{ppm}$ & 677 & 0.15 & 67.16 & 677 & $<1$ \\
\hline $\mathrm{La}, \mathrm{ppm}$ & 740 & 0.16 & 73.41 & 740 & $<1$ \\
\hline Nd, ppm & 507 & 0.11 & 50.29 & 507 & $<1$ \\
\hline
\end{tabular}

VIM 4 test work was conducted to demonstrate that carbon dioxide must not be sparged into the system until the metal is molten. The test conditions were similar to VIM 3 except carbon dioxide was not supplied until a molten bath formed. Sparging carbon dioxide onto the surface was continued for one hour. The results are presented in Table 4.20.

Note that surrogates (the goal was to lower the surrogate concentration to less than one ppm) and carbon (the goal was to lower the carbon concentration to less than $300 \mathrm{ppm}$ ) were successfully removed from the stainless steel without the oxidation and removal of chromium or nickel. The 
model calculations are also in qualitative agreement with the experimental results (except for silicon).

Air sparging was also investigated, VIM 5. The test conditions and experimental results are presented in Table 4.21. Air was sparged onto the surface of the molten metal for one hour at approximately one CFM. The results show that better molten metal/gas contact is required to lower the surrogates and carbon to the desired concentrations. It is also evident that air sparging results in a greater loss of chromium from the metal phase than when carbon dioxide is used as the oxidant.

\subsection{SOLID OXIDIZER: MAGNETITE}

Several tests were conducted to investigate surrogate removal and decarburization of stainless steel using magnetite as a solid oxidant, e.g., VIM 6, VIM 7, VIM 8.

\section{VIM 6, VIM 7, VIM 8}

Magnetite was tested as a solid oxidant for selectively removing the surrogates and carbon in preference to chromium. Various amounts of magnetite were added to the molten stainless baths under the conditions presented in Tables 4.22 through 4.24 .

The stoichiometric requirement of magnetite for removal of the surrogates (to less than one ppm) and carbon (to less than $300 \mathrm{ppm}$ ) is approximately one pound (for 250 pounds of feed metal). Note that for acceptable surrogate and carbon removal two pounds were experimentally required. However, the quantity of magnetite required has not been optimized. Much of the magnetite added to each experimental test was deposited in a splatter ring located just above the molten metal surface. The proper mode of introduction of the solid oxidant into the molten bath has yet to be determined. 
TABLE 4.20. VIM 4: VACUUM INDUCTION MELTING OF STAINLESS STEEL IN THE PRESENCE OF CARBON DIOXIDE

\begin{tabular}{|c|c|c|c|c|c|c|c|c|c|c|c|}
\hline \multicolumn{12}{|c|}{$\begin{array}{l}\text { VIM } 4 \\
\text { CONDITIONS: } \\
\text { Date: } 9 / 30 / 95 \\
\text { Temp: } 1600-1650 \\
\text { Atm: Vacuum, CO2 on Surface for } 1 \text { Hr at } 1 \mathrm{SCFM} \\
\text { Pressure: } 0.1 \text { Atm } \\
\text { Ingot: } 220 \text { pounds; Flange } 16 \text { pounds; Pipe } 14 \text { pounds } \\
\text { CO2 Input: } 3338.6 \text { grams } \\
\text { Time at Temperature: } 1.0 \text { Hour }\end{array}$} \\
\hline \multicolumn{12}{|l|}{ RESULTS: } \\
\hline \multirow[t]{2}{*}{ ELEMENT } & INGOT & FLANGE & PIPE & INGOT & FLANGE & PIPE & TOTAL & TOTAL & IN & OUT & CALC \\
\hline & WT\% & WT\% & WT\% & LBS & LBS & LBS & LBS & GMS & PPM & PPM $^{*}$ & PPM \\
\hline $\mathrm{C}$ & 0.11 & 0.23 & 0.09 & 0.24 & 0.04 & 0.01 & 0.29 & 133 & 1175 & 226 & 171 \\
\hline $\mathrm{Fe}$ & & & & 161.06 & 15.74 & 13.93 & 190.74 & 86594 & 762942 & - & 746500 \\
\hline $\mathrm{Cr}$ & 18.00 & & & 39.60 & 0.00 & 0.00 & 39.60 & 17980 & 158400 & 160000 & 150100 \\
\hline $\mathrm{Ni}$ & 10.40 & & & 20.13 & 0.00 & 0.00 & 20.13 & 9139 & 80520 & 89800 & 93370 \\
\hline $\mathrm{Si}$ & 0.32 & 0.27 & & 0.70 & 0.04 & 0.00 & 0.75 & 339 & 2989 & 4500 & 680 \\
\hline $\mathrm{Mn}$ & 1.34 & 1.10 & 0.41 & 2.95 & 0.18 & 0.06 & 3.18 & 1444 & 12726 & 9700 & 8953 \\
\hline $\mathrm{Ce}, \mathrm{ppm}$ & 210.00 & 1.70 & & 0.05 & 0.00 & 0.00 & 0.05 & 21 & 186 & $<1$ & $<1$ \\
\hline $\mathrm{La}, \mathrm{ppm}$ & 200.00 & 1.50 & & 0.04 & 0.00 & 0.00 & 0.04 & 20 & 176 & $<1$ & $<1$ \\
\hline $\mathrm{Nd}, \mathrm{ppm}$ & 280.00 & & & 0.06 & 0.00 & 0.00 & 0.06 & 28 & 246 & $<1$ & $<1$ \\
\hline
\end{tabular}


TABLE 4.21. VIM 5: VACUUM INDUCTION MELTING OF STAINLESS STEEL IN THE PRESENCE OF AIR

\begin{tabular}{|c|c|c|c|c|c|c|c|c|c|c|c|}
\hline \multicolumn{12}{|c|}{$\begin{array}{l}\text { VIM } 5 \\
\text { CONDITIONS: } \\
\text { Date: } 9 / 27 / 95 \\
\text { Temp: } 1600-1650 \\
\text { Atm: Vacuum, Air on Surface for } 1 \text { Hr at } 2 \text { SCFM } \\
\text { Pressure: } 50 \text { Torr } \\
\text { Ingot: } 218.5 \text { pounds; Flange } 16 \text { pounds; Pipe } 14 \text { pounds } \\
\text { Air Input: } 970 \text { grams O2; } 3396 \text { grams N2 } \\
\text { Time at Temperature: } 1.0 \text { Hour } \\
\text { RESULTS: }\end{array}$} \\
\hline \multirow[t]{2}{*}{ ELEMENT } & INGOT & FLANGE & PIPE & INGOT & FLANGE & PIPE & TOTAL & TOTAL & IN & OUT & CALC \\
\hline & WT\% & WT\% & WT\% & LBS & LBS & LBS & LBS & GMS & PPM & PPM* & PPM \\
\hline $\mathrm{C}$ & 0.10 & 0.23 & 0.09 & 0.23 & 0.04 & 0.01 & 0.28 & 126.20 & 1116 & 566 & 9 \\
\hline $\mathrm{Fe}$ & & & & 151.99 & 15.74 & 14.53 & 182.26 & 82746.64 & 731679 & - & 704000 \\
\hline $\mathrm{Cr}$ & 18.00 & & & 39.60 & 0.00 & 0.00 & 39.60 & 17978.40 & 158972 & 165300 & 152800 \\
\hline $\mathrm{Ni}$ & 10.40 & & & 22.88 & 0.00 & 0.00 & 22.88 & 10387.52 & 91851 & 94800 & 92620 \\
\hline $\mathrm{Si}$ & 0.32 & 0.27 & & 0.70 & 0.04 & 0.00 & 0.75 & 339.23 & 3000 & 4200 & 890 \\
\hline $\mathrm{Mn}$ & 1.34 & 1.10 & 0.41 & 2.95 & 0.18 & 0.06 & 3.18 & 1444.36 & 12772 & 11800 & 9686 \\
\hline $\mathrm{Ce}, \mathrm{ppm}$ & 210.00 & 1.70 & & 0.05 & 0.00 & 0.00 & 0.05 & 21.10 & 187 & 1 & $<1$ \\
\hline $\mathrm{La}, \mathrm{ppm}$ & 200.00 & 1.50 & & 0.04 & 0.00 & 0.00 & 0.04 & 19.99 & 177 & $<1$ & $<1$ \\
\hline $\mathrm{Nd}, \mathrm{ppm}$ & 280.00 & & & 0.06 & 0.00 & 0.00 & 0.06 & 27.97 & 247 & 2 & $<1$ \\
\hline
\end{tabular}


TABLE 4.22. VIM 6: VACUUM INDUCTION MELTING OF STAINLESS STEEL USING MAGNETITE AS AN OXIDANT

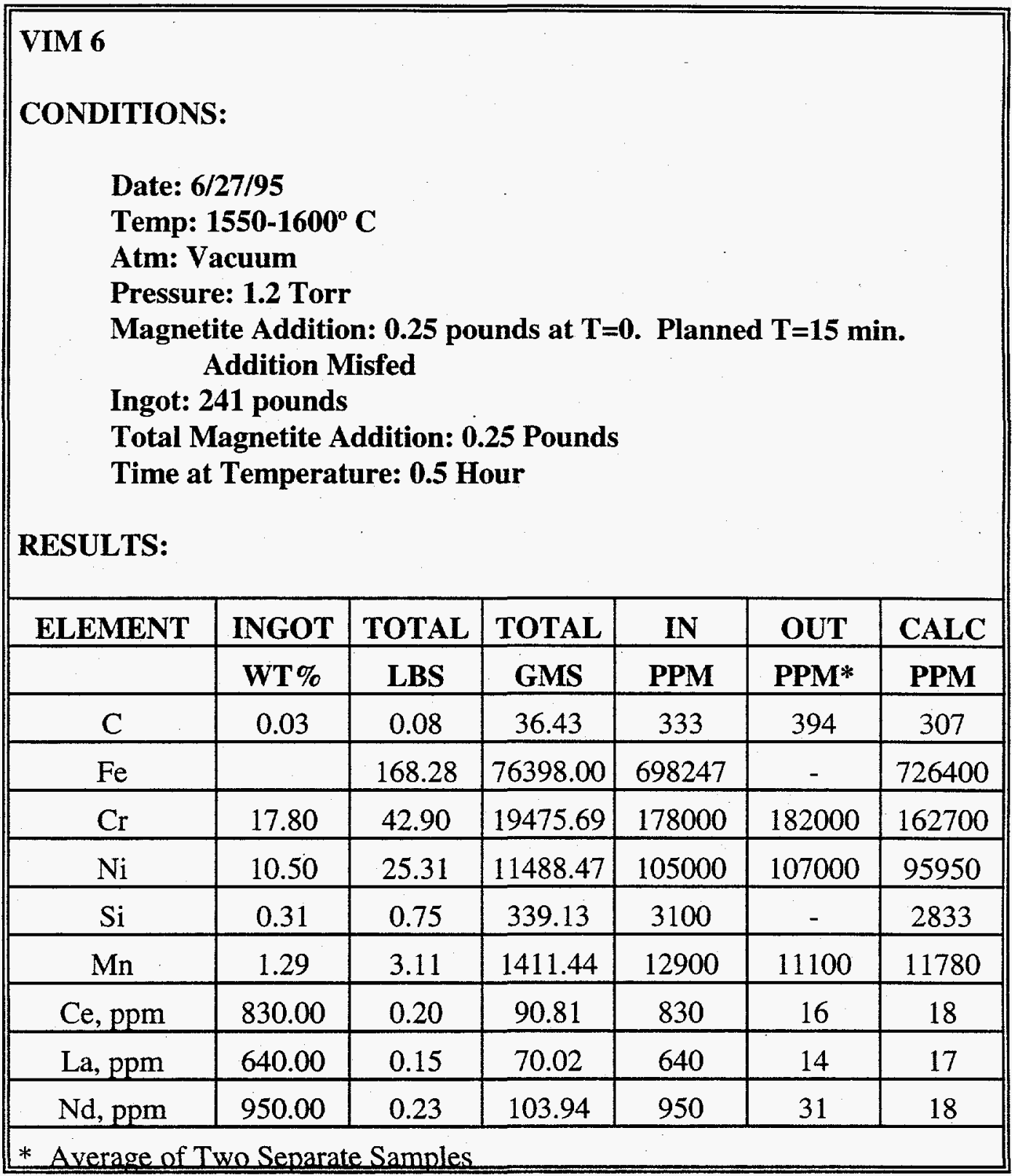


TABLE 4.23. VIM 7: VACUUM INDUCTION MELTING OF STAINLESS STEEL USING MAGNETITE AS AN OXIDANT

\begin{tabular}{|c|c|c|c|c|c|c|c|}
\hline \multicolumn{8}{|c|}{$\begin{array}{l}\text { VIM } 7 \\
\text { CONDITIONS: }\end{array}$} \\
\hline \multicolumn{8}{|c|}{ CONDITIONS: } \\
\hline \\
\hline & & \multicolumn{6}{|c|}{ Temp: 1600-1650 } \\
\hline Atm: & & & & & & & \\
\hline \multicolumn{8}{|c|}{ Pressure: 2 Torr } \\
\hline \multirow{4}{*}{\multicolumn{8}{|c|}{$\begin{array}{l}\text { Magnetite Addition: } 1 \text { pound at } T=0,1 \text { pound at } T=0.5 \mathrm{Hr} \\
\text { Ingot: } 215.5 \text { pounds } \\
\text { Total Magnetite Addition: } 2 \text { Pounds } \\
\text { Time at Temperature: One hour }\end{array}$}} \\
\hline & & & & & & & \\
\hline & & & & & & & \\
\hline & & & & & & & \\
\hline \multicolumn{8}{|l|}{ RESULTS: } \\
\hline \multirow[t]{3}{*}{ ELEMENT } & INGOT & TOTAL & TOTAL & IN & OUT & CALC & CALC \\
\hline & & & & & & $\begin{array}{c}\text { FOR 1 } \\
\text { LB } \\
\text { FE304 } \\
\end{array}$ & $\begin{array}{c}\text { FOR } 2 \\
\text { LBS } \\
\text { FE304 } \\
\end{array}$ \\
\hline & WT\% & LBS & GMS & PPM & PPM* & PPM & PPM \\
\hline $\mathrm{C}$ & 0.11 & 0.23 & 103.71 & 1062 & 946 & 211 & 7 \\
\hline $\mathrm{Fe}$ & & 150.51 & 68331.32 & 698420 & & 691800 & 69630 \\
\hline $\mathrm{Cr}$ & 17.90 & 38.57 & 17512.82 & 179000 & 178000 & 182300 & 181300 \\
\hline $\mathrm{Ni}$ & 10.40 & 22.41 & 10175.05 & 104000 & 103700 & 106000 & 105800 \\
\hline $\mathrm{Si}$ & 0.32 & 0.69 & 313.08 & 3200 & 3700 & 3261 & 2767 \\
\hline Mn & 1.36 & 2.93 & 1330.58 & 13600 & 10800 & 13860 & 13370 \\
\hline $\mathrm{Ce}, \mathrm{ppm}$ & 220.00 & 0.05 & 21.52 & 220 & $<1$ & 7 & $<1$ \\
\hline $\mathrm{La}, \mathrm{ppm}$ & 210.00 & 0.05 & 20.55 & 210 & $<1$ & 9 & $<1$ \\
\hline $\mathrm{Nd}, \mathrm{ppm}$ & 290.00 & 0.06 & 28.37 & 290 & $<1$ & 8 & $<1$ \\
\hline
\end{tabular}


$\Sigma$

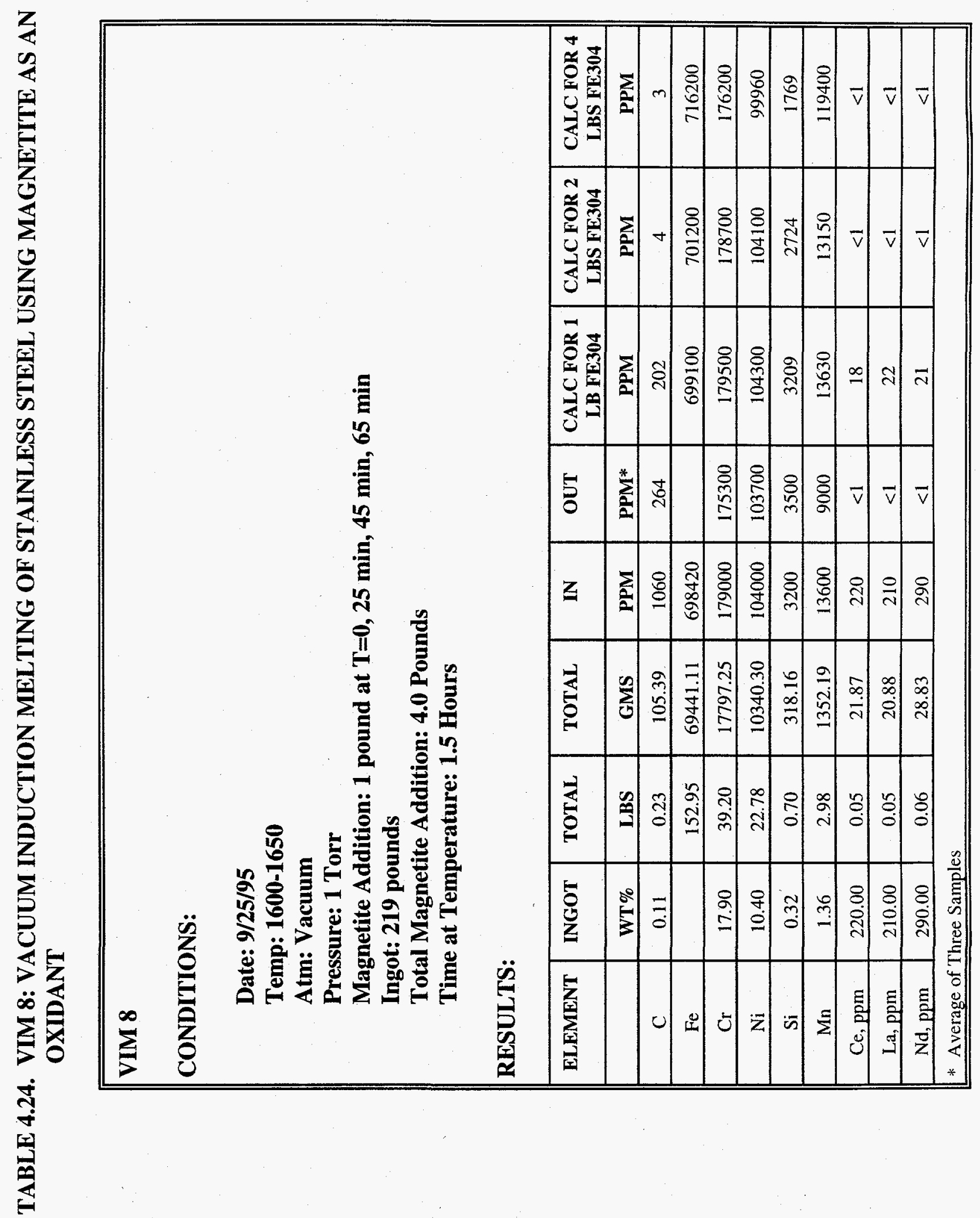




\subsubsection{SUMMARY OF VIM TEST WORK}

The vacuum induction melt test work has demonstrated that surrogate elements can be effectively lowered to below one part per million by melting in a vacuum, by sparging carbon dioxide into the vacuum chamber or onto the molten metal surface, by sparging air onto the molten metal surface, and by the addition of magnetite to the molten metal bath. The test work has also demonstrated that decarburization of the melt can be accomplished by sparging carbon dioxide onto the molten metal bath or by the addition of magnetite to the molten metal bath. Both removal of surrogate elements and decarburization can be accomplished without loss of chromium in reasonable process times without use of immersed sparging or bottom blowing.

\subsubsection{ATTAINMENT OF GOALS FOR THE PILOT SCALE TEST WORK}

The goals of the pilot scale test work included:

- The evaluation of whether effective surrogate removal could be accomplished using plasma torch melting under controlled oxidation potential conditions (applied to approximately two hundred pounds of surrogate loaded stainless steel).

Attainment of goal: The pilot scale plasma melt tests demonstrated that effective surrogate removal $(<1 \mathrm{ppm})$ was achieved under the following specific conditions: feed rate, $20 \mathrm{~cm} / \mathrm{hr} ; 10 \% \mathrm{O}_{2}$ supplied through the torch during melting.

- The evaluation of whether effective surrogate removal and carbon reduction could be accomplished by vacuum induction melting (VIM) under controlled oxygen potential (applied to approximately two hundred pounds of surrogate loaded stainless steel).

Attainment of goal: The VIM series of tests demonstrated that surrogate elements can be effectively lowered to below one part per million by melting in a vacuum, by sparging carbon dioxide into the vacuum chamber or onto the molten metal surface, by sparging air onto the molten metal surface, and by the addition of magnetite to the molten metal bath. The test work has also demonstrated that decarburization of the melt can be accomplished by sparging carbon dioxide onto the molten metal bath or by the addition of magnetite to the molten metal bath. Both removal of surrogate elements and decarburization can be accomplished in a single melting step without appreciable loss of chromium from the metal phase.

\subsection{COMMERCIAL SCALE AIR INDUCTION MELT TEST PROGRAM}

Two commercial scale air induction melt programs were conducted; one at the Anaconda Foundry and Fabrication Company (AFFCO) in Anaconda, Montana and one at Newport News in Newport, Virginia. A description of the facilities, test procedures and test results are discussed below.

\subsubsection{GOALS OF THE COMMERCIAL SCALE AIR INDUCTION TEST WORK}


The goals of the commerical scale test work were the demonstration and verification that the basic information generated during the laboratory scale test work could be successfully transferred to a full scale operational facility.

\subsubsection{AFFCO DEMONSTRATION TEST}

This commercial scale test (using a typical production foundry induction furnace) was conducted to demonstrate that induction melting would successfully verify the previous laboratory scale test results, i.e., that the surrogate concentrations would be lowered to less than one part per million. The test program was funded, designed, managed and supervised by Montana Tech personnel.

\subsubsection{INITIAL CONDITIONS FOR THE AFFCO TEST}

The test work was performed at AFFCO (located in Anaconda, Montana). The test involved melting 227 kilograms of master surrogate with 726 kilograms of 304 stainless steel in an open atmosphere induction furnace. AFFCO typically uses Allied Dri-Vibe 437A refractory as their crucible liner. This is the same liner used in the Montana Tech laboratory scale induction furnace. Before the melt, the induction furnace crucible was flushed with a charge of 301 stainless steel to clean up any previous contamination.

The test procedure consisted of placing ingots of master alloy and stainless steel in the crucible chamber (approximately 410 kilograms of master surrogate ingot and scrap metal were loaded into the induction furnace. Once this charge was molten additional stainless steel scrap was added until 953 kilograms of charge was present), heating in air to melt the charge, and holding in the molten state for a specific time. After the desired air exposure the molten charge was poured into previously prepared sand molds.

\subsubsection{TEST RESULTS}

The results for the large scale induction melt were very similar to the small scale tests performed earlier at Montana Tech. All surrogate concentrations were $<1.0 \mathrm{ppm}$. Analytical results for the metal and slag are presented in Tables 4.25 and 4.26 , respectively.

\subsection{METAL ANALYSES}

The results presented in Table 4.25 are for samples taken at timed intervals. Time zero was taken to be when the entire stainless steel charge was completely molten. Twenty one minutes before $t$ $=0$ the charge was almost completely molten and a sample was taken, $\mathrm{t}=-21$ minutes. The analytical results for this time show that all the surrogate had been removed to below ICP detection limits. Notice also that the concentrations of both $\mathrm{Cr}$ and $\mathrm{Mn}$ are not significantly reduced. The longer the charge was held in the molten condition, the lower the Mn concentration. This is shown in Table 4.25, i.e., from $\mathrm{t}=0$ to $\mathrm{t}=78$ minutes the $\mathrm{Mn}$ concentration decreased from 1.52 to $1.41 \%$. The Cr concentration remained at approximately $18.2 \%$ from $t=-21$ to $t=78$ minutes. 
TABLE 4.25. METAL PHASE ANALYSES FOR THE AFFCO COMMERCIAL SCALE MELT

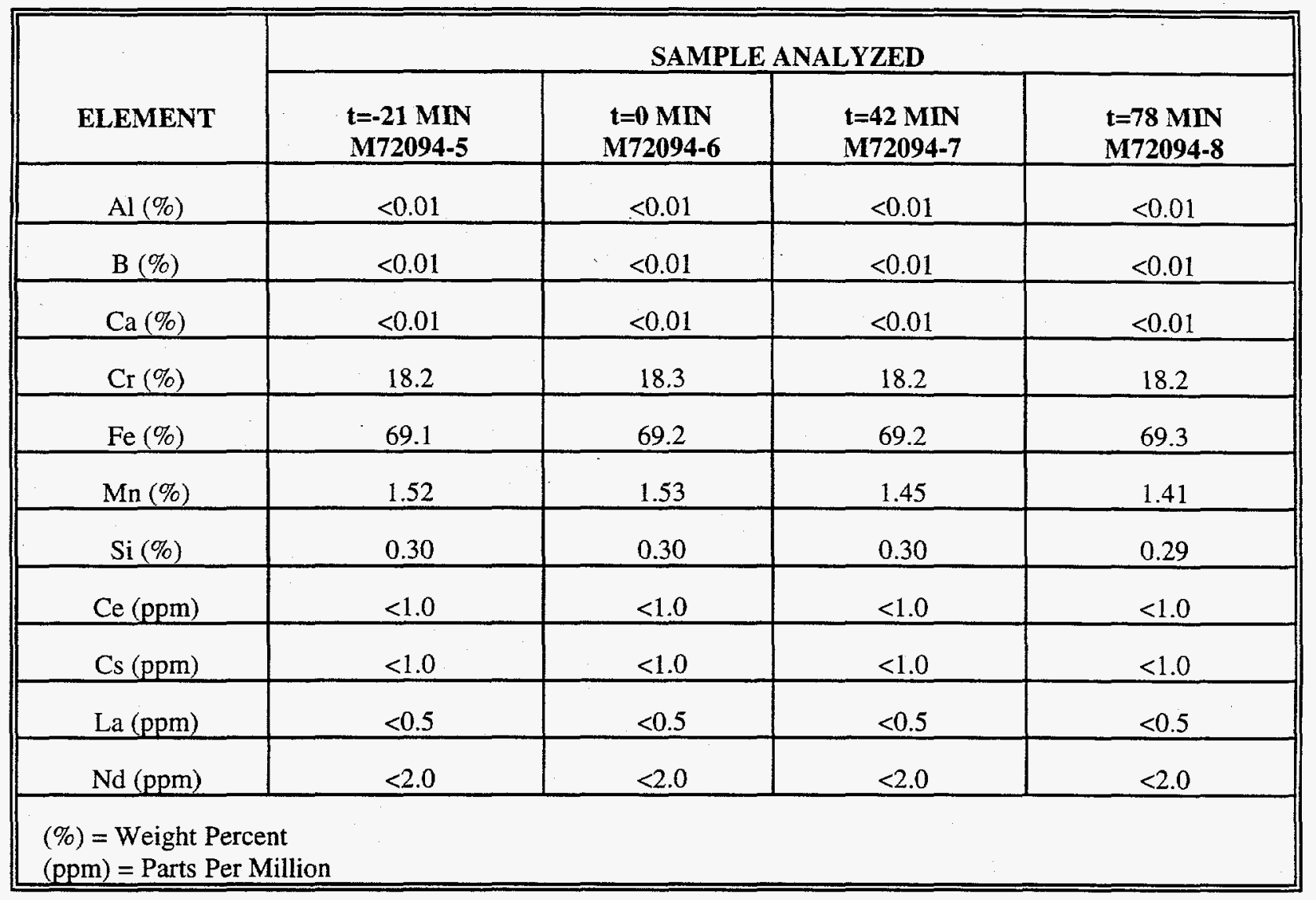

Comments concerning the test results are presented below:

- The AFFCO test melt verified the small scale experiments at Montana Tech. Surrogates were lowered to less than $1.0 \mathrm{ppm}$. Chromium, Mn and Si decreased only slightly with time.

- At $\mathrm{t}=0$ the surrogates were already $<1.0 \mathrm{ppm}$.

- The creation of effluent fume and dust was minimal. However, no attempt was made to quantify the amount created.

\subsection{SLAG ANALYSES}

The slag analyses were performed by X-Ray fluorescence spectroscopy and the data are presented in Table 4.26. Slag samples were obtained by skimming the slag/(oxide products) from the molten metal surface, with a stainless steel bar, at various time intervals. 
TABLE 4.26. SLAG ANALYSES OF THE AFFCO COMMERCIAL SCALE MELT

\begin{tabular}{|c|c|c|c|}
\hline \multirow[b]{2}{*}{ ELEMENT } & \multicolumn{3}{|c|}{ SAMPLE ANALYZED } \\
\hline & $\begin{array}{c}t=-13 \mathrm{MIN} . \\
\mathbf{S 7 2 2 9 4 - 3}\end{array}$ & $\begin{array}{l}t=4 \text { MIN. } \\
\text { S72294-1 }\end{array}$ & $\begin{array}{r}t=16 \mathrm{MIN} \\
\mathbf{S} 72294-2 \\
\end{array}$ \\
\hline $\mathrm{Mg}(\mathrm{ppm})$ & 8200 & 12500 & 11500 \\
\hline $\mathrm{Al}$ (ppm) & 97000 & 144000 & 154000 \\
\hline $\mathrm{Si}(\mathrm{ppm})$ & 221000 & 258000 & 249000 \\
\hline $\mathrm{Ca}(\mathrm{ppm})$ & 3600 & 3600 & 4000 \\
\hline $\mathrm{Cr}(\mathrm{ppm})$ & 25800 & 24400 & 22800 \\
\hline $\mathrm{Mn}(\mathrm{ppm})$ & 47800 & 43800 & 41600 \\
\hline $\mathrm{Fe}(\mathrm{ppm})$ & 1280 & 2800 & 1150 \\
\hline $\mathrm{Co}(\mathrm{ppm})$ & N.D. & N.D. & N.D. \\
\hline $\mathrm{Ni}(\mathrm{ppm})$ & 155 & 240 & 120 \\
\hline $\mathrm{Sr}(\mathrm{ppm})$ & 20 & 34 & 30 \\
\hline Cs (ppm) & N.D. & N.D. & N.D. \\
\hline $\mathrm{La}(\mathrm{ppm})$ & 2600 & 756 & 575 \\
\hline $\mathrm{Ce}(\mathrm{ppm})$ & 3420 & 1110 & 837 \\
\hline $\mathrm{Nd}(\mathrm{ppm})$ & 2100 & 720 & 394 \\
\hline
\end{tabular}

Comments concerning the test results are presented below:

- The first skimming contained the highest surrogate loading. The loading decreased with time. Since the metal was essentially decontaminated at $t=-21$ minutes the decrease in surrogate content in the slag likely reflects dilution by "popcorn" additions.

- Strontium remained remarkably consistent with melt time.

- Chromium and Mn were relatively high in the slag even though little of either was lost from the metal phase. This effect is simply because such a small amount of slag is formed during treatment period. 


\subsection{DISTRIBUTION RATIO}

Distribution ratios are presented in Table 4.27. The distribution ratio for metal sample M72094-5 ( $t=-21$ minutes) was calculated using the slag sample S72294-3 $(t=-13$ minutes). The distribution ratio for metal sample M72094-6 $(t=0)$ was calculated using slag sample S72294-1 $(t=4$ minutes). From the distribution ratios it is evident that most of the surrogates were oxidized early in the melting process, i.e., at least before $\mathrm{t}=-21$ minutes.

TABLE 4.27. DISTRIBUTION RATIO TABLE FOR THE AFFCO COMMERCIAL SCALE OXIDATION INDUCTION MELT

\begin{tabular}{||c|c|c|c|c|c|}
\hline Sample & Ce & La & Nd & Cs & Sr \\
\hline $\begin{array}{c}\text { M72094-5/ } \\
\text { S72294-3 }\end{array}$ & $>3420$ & $>5200$ & $>1050$ & N.A. & N.A. \\
\hline $\begin{array}{c}\text { M72094-6/ } \\
\text { S72294-1 }\end{array}$ & $>1110$ & $>1512$ & $>360$ & N.A. & N.A. \\
\hline N.A.-Not available
\end{tabular}

\subsubsection{NEWPORT NEWS DEMONSTRATION TEST}

This commercial scale test was conducted to demonstrate that induction melting would successfully verify the previous laboratory scale test results, i.e., that the surrogate concentrations would be lowered to less than one part per million. The test program was funded by WINCO (except for the analytical test work) under a Cooperative Research and Development Agreement (CRADA) with Newport News. The test plan was cooperatively designed by WINCO and Montana Tech personnel, managed and supervised by WINCO and Montana Tech personnel, and all analytical test work was coordinated and funded by the Montana Tech program.

\subsubsection{INITIAL CONDITIONS FOR NEWPORT NEWS TEST}

The second pilot scale stainless steel decontamination induction melt was performed at Newport News Shipbuilding and Dry Dock Company (NNS) in Newport, Virginia. The charge was composed of a 552 kilogram master surrogate ingot and 456 kilograms of AFFCO decontaminated stainless steel. Approximately $2 \%$ (20 kilograms) of "Borate" flux $\left(32 \% \mathrm{SiO}_{2}, 42 \% \mathrm{CaO}, 10 \% \mathrm{Al}_{2} \mathrm{O}_{3}\right.$, and $16 \% \mathrm{Fe}_{2} \mathrm{O}_{3}$ ) was added to the charge before heating the furnace. The same crucible refractory (Allied Dri-Vibe 437A) that AFFCO used was sintered into the NNS furnace for this pilot scale experiment. Background off-gas was monitored by WINCO personnel throughout the test period. Ferromanganese and ferro-silicon additions were made to deoxidize the melt just prior to when the gate sample was taken. 


\subsubsection{TEST RESULTS}

Near the end of the melt, molten metal leaked out the crucible side and on to the floor. This occurrance was most likely caused by incomplete high temperature sintering of the crucible mix prior to the test. The pour temperature from the tilt induction furnace to the ladle was only $2740^{\circ} \mathrm{F}$. The metal phase analytical results are presented in Table 4.28.

\subsection{METAL ANALYSES}

The results of the NNS pilot scale melt were similar to the results achieved in the AFFCO melt. All of the surrogate concentrations were reduced to less than $1 \mathrm{ppm}$ (except for Ce in sample M9994-1).

\section{TABLE 4.28. METAL PHASE ANALYSES FOR THE NNS COMMERCIAL SCALE INDUCTION MELT}

\begin{tabular}{|c|c|c|c|}
\hline \multirow[b]{2}{*}{ Element } & \multicolumn{3}{|c|}{ Sample Analyzed } \\
\hline & $\begin{array}{c}\text { Prepour S1 } \\
\text { T=-32 (Min) } \\
\text { M9994-3 }\end{array}$ & $\begin{array}{c}\text { Prepour S2 } \\
T=69 \text { (Min) } \\
\text { M9994-2 }\end{array}$ & $\begin{array}{c}\text { Gate Sample } \\
\text { T=93 (Min) } \\
\text { M9994-1 }\end{array}$ \\
\hline $\mathrm{Al}(\%)$ & $<0.01$ & $<0.01$ & $<0.01$ \\
\hline $\mathrm{B}(\%)$ & $<0.0005$ & $<0.0005$ & $<0.0005$ \\
\hline $\mathrm{C}(\mathrm{ppm})$ & 424 & 460 & 424 \\
\hline $\mathrm{Ca}(\%)$ & $<0.010$ & $<0.010$ & $<0.010$ \\
\hline $\mathrm{Co}(\%)$ & 0.129 & 0.128 & 0.122 \\
\hline $\mathrm{Cr}(\%)$ & 18.21 & 18.10 & 18.05 \\
\hline $\mathrm{Mn}(\%)$ & 1.08 & 0.99 & 1.14 \\
\hline $\mathrm{Si}(\%)$ & 0.217 & 0.179 & 0.217 \\
\hline $\mathrm{Ce}(\mathrm{ppm})$ & $<1.0$ & $<1.0$ & 1.4 \\
\hline Cs (ppm) & $<1.0$ & $<1.0$ & $<1.0$ \\
\hline $\mathrm{La}(\mathrm{ppm})$ & $<1.0$ & $<1.0$ & $<1.0$ \\
\hline $\mathrm{Nd}(\mathrm{ppm})$ & $<1.0$ & $<1.0$ & $<1.0$ \\
\hline $\mathrm{Sr}(\mathrm{ppm})$ & $<1.0$ & $<1.0$ & $<1.0$ \\
\hline
\end{tabular}


Comments concerning the test results are presented below:

- The final surrogate concentrations resulting from the large scale NNS melt were < $1 \mathrm{ppm}$. These results are similar to the large scale AFFCO melt test results and verify the Montana Tech laboratory study results.

\subsection{SLAG ANALYSES}

The analyses for the slag resulting from the NNS melt are significantly different from the AFFCO slag analyses. The slag analyses for the NNS pilot scale induction melt are presented in Table 4.29.

TABLE 4.29. SLAG ANALYSES FOR THE NNS COMMERCIAL SCALE INDUCTION MELT

\begin{tabular}{|c|c|}
\hline & SAMPLE ANALYZED \\
\cline { 2 - 3 } ELEMENTS & $\begin{array}{c}\text { SLAG } \\
\text { S11994-4 }\end{array}$ \\
\hline $\mathrm{Al} \%$ & 0.7 \\
\hline $\mathrm{Cr} \%$ & 3.5 \\
\hline $\mathrm{Fe} \%$ & 1.1 \\
\hline $\mathrm{Mn}(\%)$ & 1.7 \\
\hline $\mathrm{Si}(\%)$ & 9.5 \\
\hline $\mathrm{Ce}(\mathrm{ppm})$ & 190 \\
\hline $\mathrm{La}(\mathrm{ppm})$ & 160 \\
\hline $\mathrm{Nd}(\mathrm{ppm})$ & 930 \\
\hline $\begin{array}{l}\text { \% } \\
\text { \% }\end{array}$ & \\
\hline peight Percent $=$ Parts Per Million & \\
\hline
\end{tabular}

Comments concerning the test results are presented below:

- It has been noted in other test work that surrogate element concentrations in the slag phase (when essentially complete removal has occurred from the metal phase) are very low. It is our conclusion at this time that the surrogates are "gettered" out by the refractory crucible. Analysis of the induction crucible material has not been performed in this study. 


\subsection{DISTRIBUTION RATIO}

Distribution ratios are presented in Table 4.30 for the NNS pilot scale melt. The distribution ratios for this test are considerable less than those reported for the other large scale test, i.e., the AFFCO test. The reason for the difference is because of the volume of slag present in each treatment was considerably different. The AFFCO test generated a relatively small amount of slag (no flux was added to the system, except "popcorn" was added to collect the slag immediately before skimming), whereas two percent flux was added prior to the melting test at Newport News.

\section{TABLE 4.30. DISTRIBUTION RATIO TABLE FOR THE NNS COMMERCIAL SCALE INDUCTION OXIDATION MELT}

\begin{tabular}{|c|c|c|c|c|c|}
\hline SAMPLE & Ce & La & Nd & Cs & Sr \\
\hline $\begin{array}{c}\text { S11994-4/ } \\
\text { M9994-2 }\end{array}$ & $>190$ & $>160$ & $>930$ & N.A. & N.A. \\
\hline N.A.-Not available
\end{tabular}

\subsubsection{ATTAINMENT OF GOALS FOR THE COMMERCIAL SCALE AIR INDUCTION MELT TESTS}

The goals of the commerical scale test work were the demonstration and verification that the basic information generated during the laboratory scale test work could be successfully transferred to a full scale operational facility. These goals were achieved by both of the commercial scale test programs, e.g., the surrogate concentrations were lowered to less than one ppm in both tests.

\subsection{STAINLESS STEEL MELT PROGRAM: COMPARISON OF RESULTS}

For the convenience to the reader compilations of the pilot scale cold hearth plasma, air induction test and commercial results are presented in Tables 4.31 and 4.32.

\section{TABLE 4.31. COMPILATION OF PILOT SCALE AND COMMERCIAL SCALE MELT TESTS: METAL PHASE ANALYSES}

\begin{tabular}{|c|c|c|c|c|c|c|c|}
\hline \multirow[b]{2}{*}{$\begin{array}{c}\text { SAMPLE } \\
\text { ANALYZED }\end{array}$} & \multicolumn{7}{|c|}{ ELEMENT CONCENTRATION } \\
\hline & $\begin{array}{c}\mathbf{C e} \\
\text { (ppm) }\end{array}$ & $\begin{array}{c}\mathbf{L a} \\
\text { (ppm) }\end{array}$ & $\begin{array}{c}\text { Nd } \\
(\mathbf{p p m})\end{array}$ & $\begin{array}{c}\text { Cs } \\
\text { (ppm) }\end{array}$ & $\begin{array}{c}\mathbf{S r} \\
\text { (ppm) }\end{array}$ & $\begin{array}{r}\mathrm{Cr} \\
(\%) \\
\end{array}$ & $\begin{array}{l}\text { Mn } \\
(\%) \\
\end{array}$ \\
\hline \multicolumn{8}{|c|}{$\begin{array}{c}\text { First Controlled Oxidation Plasma Melt With an Oxidizing Flux: ICP-MS } \\
\text { (Fluxes: Borate and Borate Without Ferric Oxide-Two Weight Percent) } \\
\text { Reference Section 4.1.2.2 for Details }\end{array}$} \\
\hline WFe1 & 360 & 160 & 340 & $<1.0$ & $<1.0$ & 18.7 & 1.41 \\
\hline $\mathrm{WFe} 2$ & 250 & 220 & 300 & $<1.0$ & $<1.0$ & 18.8 & 1.40 \\
\hline WFe3 & 53 & 22 & 35 & $<1.0$ & $<1.0$ & 18.3 & 1.48 \\
\hline
\end{tabular}


ELEMENT CONCENTRATION

\begin{tabular}{|c|c|c|c|c|c|c|c|}
\hline \multirow[b]{2}{*}{$\begin{array}{l}\text { SAMPLE } \\
\text { ANALYZED }\end{array}$} & \multicolumn{7}{|c|}{ ELEMENT CONCENTRATION } \\
\hline & $\begin{array}{c}\text { Ce } \\
(\mathrm{ppm})\end{array}$ & $\begin{array}{c}\text { La } \\
(\mathrm{ppm})\end{array}$ & $\begin{array}{c}\text { Nd } \\
(\mathbf{p p m})\end{array}$ & $\begin{array}{c}\text { Cs } \\
(\mathbf{p p m})\end{array}$ & $\begin{array}{c}\mathrm{Sr} \\
(\mathbf{p p m})\end{array}$ & $\begin{array}{c}\mathbf{C r} \\
(\%)\end{array}$ & $\begin{array}{l}\text { Mn } \\
(\%) \\
\end{array}$ \\
\hline $\mathrm{NFe} 1$ & 360 & 150 & 290 & $<1.0$ & $<1.0$ & 18.6 & 1.40 \\
\hline $\mathrm{NFe} 2$ & 250 & 100 & 240 & $<1.0$ & $<1.0$ & 18.6 & 1.40 \\
\hline $\mathrm{NFe} 3$ & 120 & 64 & 110 & $<1.0$ & 16 & 18.6 & 1.42 \\
\hline \multicolumn{8}{|c|}{$\begin{array}{c}\text { Second Controlled Oxidation Plasma Melt With an Oxidizing Flux: ICP-MS } \\
\text { (Fluxes: Borate and Ferrite-Five Weight Percent) } \\
\text { Reference Section 4.1.2.3 for Details }\end{array}$} \\
\hline M52694T & 30 & 19 & 24 & $<0.5$ & 8.7 & 18.8 & 1.31 \\
\hline M52694s & 14 & 4.9 & 13 & $<0.5$ & $<0.5$ & 19.1 & 1.27 \\
\hline M52794S & 8.0 & 4.8 & 7.8 & $<0.5$ & 0.8 & 18.5 & 1.07 \\
\hline M52794T & 22 & 14 & 20 & $<0.5$ & 4.5 & 17.7 & 18.5 \\
\hline \multicolumn{8}{|c|}{$\begin{array}{l}\text { Controlled Oxidation Melt With } 2 \% \mathrm{O}_{2} \text { in Helium: ICP-MS } \\
\text { Reference Section 4.1.2.4. for Details }\end{array}$} \\
\hline M72094-1 & 280 & 290 & 280 & N.A. & N.A. & 18.4 & 1.40 \\
\hline M72094-4 & 120 & 51 & 92 & N.A. & N.A. & 18.3 & 1.51 \\
\hline M72094-3 & 33 & 18 & 23 & N.A. & N.A. & 18.3 & 1.33 \\
\hline M72094-2 & 9.2 & 6.3 & 6.2 & N.A. & N.A. & 18.2 & 1.44 \\
\hline \multicolumn{8}{|c|}{$\begin{array}{c}\text { Controlled Oxidation Plasma Melt With } 5 \% \mathrm{O}_{2} \text { in Helium: ICP-MS } \\
\text { Reference Section 4.1.2.5 for Details }\end{array}$} \\
\hline M9294-1 & $<1.0$ & 7.4 & 11 & N.A. & N.A. & N.A. & N.A. \\
\hline M9294-2 & $<1.0$ & 22 & 28 & N.A. & N.A. & N.A. & N.A. \\
\hline M9294-3 & $<1.0$ & $<1.0$ & 1.2 & N.A. & N.A. & N.A. & N.A. \\
\hline M9294-4 & $<1.0$ & 1.8 & 2.8 & N.A. & N.A. & N.A. & N.A. \\
\hline M9294-5 & $<1.0$ & 33 & 78 & N.A. & N.A. & N.A. & N.A. \\
\hline \multicolumn{8}{|c|}{$\begin{array}{l}\text { Controlled Oxidation Plasma Melt With } 5 \% \text { and } 10 \% \mathrm{O}_{2} \text { in Helium (With a Refractory Lining: ICP-MS) } \\
\text { Reference Section 4.1.2.6 for Details }\end{array}$} \\
\hline M102494-1 & 75 & 67 & 79 & N.A. & N.A. & N.A. & N.A. \\
\hline M102494-2 & 130 & 210 & 210 & N.A. & N.A. & N.A. & N.A. \\
\hline \multicolumn{8}{|c|}{$\begin{array}{l}\text { Controlled Oxidation Plasma Melt With } 10 \% \mathrm{O}_{2} \text { in Argon: ICP-MS } \\
\text { Reference Section 4.1.2.7 for Details }\end{array}$} \\
\hline M1695-A & 73 & 64 & 80 & N.A. & N.A. & N.A. & N.A. \\
\hline M1695-B & $<1.0$ & $<1.0$ & $<1.0$ & N.A. & N.A. & N.A. & N.A. \\
\hline
\end{tabular}




\begin{tabular}{|c|c|c|c|c|c|c|c|}
\hline \multirow[b]{2}{*}{$\begin{array}{l}\text { SAMPLE } \\
\text { ANALYZED }\end{array}$} & \multicolumn{7}{|c|}{ ELEMENT CONCENTRATION } \\
\hline & $\begin{array}{c}\mathrm{Ce} \\
(\mathrm{ppm})\end{array}$ & $\begin{array}{c}\text { La } \\
(\mathrm{ppm})\end{array}$ & $\begin{array}{c}\text { Nd } \\
(\mathrm{ppm})\end{array}$ & $\begin{array}{c}\text { Cs } \\
(\mathrm{ppm})\end{array}$ & $\begin{array}{c}\mathrm{Sr} \\
(\mathrm{ppm})\end{array}$ & $\begin{array}{c}\mathrm{Cr} \\
(\%)\end{array}$ & $\begin{array}{l}\text { Mn } \\
(\%)\end{array}$ \\
\hline M1695-C & 57 & 65 & 54 & N.A. & N.A. & N.A. & N.A. \\
\hline M1695-D & $<1.0$ & $<1.0$ & $<1.0$ & N.A. & N.A. & N.A. & N.A. \\
\hline M1695-E & $<1.0$ & $<1.0$ & $<1.0$ & N.A. & N.A. & N.A. & N.A. \\
\hline \multicolumn{8}{|c|}{$\begin{array}{c}\text { Commercial Scale Air Induction Melt Performed at AFFCO: ICP-MS } \\
\text { Reference Section 4.2.2 for Details }\end{array}$} \\
\hline M72094-5 & $<1.0$ & $<0.5$ & $<2.0$ & $<1.0$ & N.A. & 18.2 & 1.52 \\
\hline M72094-6 & $<1.0$ & $<0.5$ & $<2.0$ & $<1.0$ & N.A. & 18.3 & 1.53 \\
\hline M72094-7 & $<1.0$ & $<0.5$ & $<2.0$ & $<1.0$ & N.A. & 18.2 & 1.45 \\
\hline M72094-8 & $<1.0$ & $<0.5$ & $<2.0$ & $<1.0$ & N.A. & 18.2 & 1.41 \\
\hline \multicolumn{8}{|c|}{$\begin{array}{l}\text { Large Scale Air Induction Melt Performed at Newport News: ICP-MS } \\
\text { Reference Section 4.2.3 for Details }\end{array}$} \\
\hline M9994-1 & 1.4 & $<1.0$ & $<1.0$ & $<1.0$ & $<1.0$ & 18.0 & 1.14 \\
\hline M9994-2 & $<1.0$ & $<1.0$ & $<1.0$ & $<1.0$ & $<1.0$ & 18.1 & 0.99 \\
\hline M9994-3 & $<1.0$ & $<1.0$ & $<1.0$ & $<1.0$ & $<1.0$ & 18.2 & 1.1 \\
\hline & \multicolumn{7}{|c|}{ ELEMENT CONCENTRATION } \\
\hline $\begin{array}{l}\text { SAMPLE } \\
\text { ANALYZED }\end{array}$ & $\begin{array}{c}\mathrm{Ce} \\
\text { (ppm) }\end{array}$ & $\begin{array}{c}\mathbf{L a} \\
(\mathrm{ppm})\end{array}$ & $\begin{array}{c}\text { Nd } \\
(\mathbf{p p m})\end{array}$ & $\begin{array}{c}\mathrm{C} \\
\text { (ppm) }\end{array}$ & $\begin{array}{r}\mathrm{Cr} \\
(\%) \\
\end{array}$ & $\begin{array}{c}\mathrm{Si} \\
(\%)\end{array}$ & $\begin{array}{l}\text { Mn } \\
(\%)\end{array}$ \\
\hline \multicolumn{8}{|c|}{$\begin{array}{l}\text { VIM: Vacuum Induction Melting } \\
\text { Reference Section 4.1.3 for Details }\end{array}$} \\
\hline VIM 1 & $<1$ & $\leq 1$ & $<1$ & 353 & 18.2 & 0.29 & 1.28 \\
\hline VIM 2 & $<1$ & $<1$ & $<1$ & 416 & 18.0 & 0.28 & 1.18 \\
\hline VIM 3 & $<1$ & $<1$ & $<1$ & 426 & 17.8 & 0.34 & 1.28 \\
\hline VIM 4 & $\leq 1$ & $<1$ & $<1$ & 226 & 16.0 & 0.45 & 0.97 \\
\hline VIM 5 & 1 & $<1$ & 2 & 566 & 16.5 & 0.42 & 1.18 \\
\hline VIM 6 & 16 & 17 & 18 & 394 & 16.3 & 0.28 & 1.18 \\
\hline VIM 7 & $\leq 1$ & $<1$ & $<1$ & 946 & 17.8 & 0.37 & 1.08 \\
\hline VIM 8 & $<1$ & $<1$ & $<1$ & 264 & 17.5 & 0.32 & 0.90 \\
\hline $\begin{array}{l}(\%)=\text { Weight Percer } \\
\text { (ppm) }=\text { Parts Per M } \\
\text { (1) Samples M1695 } \\
\text { cut axially in half to }\end{array}$ & 9J-E & inps & sen & 1695 & putside & ingo & ingot was \\
\hline
\end{tabular}


TABLE 4.32. COMPILATION OF PILOT SCALE AND COMMERCIAL SCALE MELT TESTS: SLAG ANALYSES

\begin{tabular}{|c|c|c|c|c|c|c|c|c|c|c|c|}
\hline \multirow{2}{*}{$\begin{array}{l}\text { SAMPLE } \\
\text { ANALYZED }\end{array}$} & \multicolumn{11}{|c|}{ ELEMENT } \\
\hline & $\begin{array}{c}\mathrm{Ce} \\
(\%)\end{array}$ & $\begin{array}{r}\text { La } \\
(\%) \\
\end{array}$ & $\begin{array}{l}\text { Nd } \\
(\%)\end{array}$ & $\begin{array}{c}\text { Cs } \\
(\mathrm{ppm})\end{array}$ & $\begin{array}{c}\mathrm{Sr} \\
(\%)\end{array}$ & $\begin{array}{c}\text { Al } \\
(\%)\end{array}$ & $\begin{array}{l}\mathrm{Ca} \\
(\%)\end{array}$ & $\begin{array}{r}\mathrm{Cr} \\
(\%)\end{array}$ & $\begin{array}{c}\mathrm{Fe} \\
(\%) \\
\end{array}$ & $\begin{array}{l}\text { Mn } \\
(\%)\end{array}$ & $\begin{array}{c}\mathrm{Si} \\
(\%) \\
\end{array}$ \\
\hline \multicolumn{12}{|c|}{$\begin{array}{l}\text { (Fluxes: "Borate" and "Borate Without Ferric Oxide"-Two Weight Percent) } \\
\text { 1.2.2 for DetailsFirst Controlled Oxidation Plasma Melt With an Oxidizing Flux: X-Ray Fluorescence }\end{array}$} \\
\hline $\begin{array}{l}\text { Without Fe } \\
\text { Hearth Slag }\end{array}$ & 2.7 & 2.7 & 2.9 & 60 & 2.5 & 4.6 & 18.4 & 0.6 & 0.6 & 1.1 & 22 \\
\hline $\begin{array}{l}\text { Without Fe } \\
\text { Crucible Slag }\end{array}$ & 2.5 & 2.5 & 2.5 & $<15$ & 2.3 & 4.6 & 18.3 & 0.6 & 0.6 & 1.1 & $\begin{array}{l}27 . \\
2\end{array}$ \\
\hline $\begin{array}{l}\text { With Fe } \\
\text { Crucible Slag }\end{array}$ & 2.8 & 2.8 & 2.7 & 18 & 3.0 & 4.5 & 18.1 & 1.1 & 0.7 & 1.9 & $\begin{array}{l}32 \\
6\end{array}$ \\
\hline $\begin{array}{l}\text { With Fe } \\
\text { Hearth Slag }\end{array}$ & 5.0 & 6.2 & 6.3 & 300 & 6.8 & 3.5 & 14.1 & 0.8 & 0.5 & 1.6 & 23. \\
\hline \multicolumn{12}{|c|}{$\begin{array}{c}\text { Second Controlled Oxidation Plasma Melt With an Oxidizing Flux:ICP-MS } \\
\text { (Fluxes: "Borate" and "Ferrite"-Five Weight Percent) } \\
\text { Reference Section 4.1.2.3 for Details }\end{array}$} \\
\hline S52694H & 0.92 & 0.74 & 0.81 & 6.2 & 0.35 & 5.41 & 30.4 & 2.84 & N.A. & 3.33 & $9^{15 .}$ \\
\hline S526941 & 0.33 & 0.22 & 0.31 & 2.1 & 0.08 & 1.41 & 19.0 & 10.8 & N.A. & 7.16 & $\begin{array}{l}10 . \\
8\end{array}$ \\
\hline S52794H & 0.92 & 0.73 & 0.82 & $<1.0$ & 0.34 & 5.57 & 33.4 & 1.99 & N.A. & 2.21 & 15 \\
\hline S52794I & 0.32 & 0.21 & 0.30 & $<1.0$ & 0.06 & 1.09 & 16.8 & 11.2 & N.A. & 7.06 & $\begin{array}{l}9.7 \\
3\end{array}$ \\
\hline \multicolumn{12}{|c|}{$\begin{array}{c}\text { Controlled Oxidation Plasma Melt With } 2 \% \mathrm{O}_{2} \text { in Helium: ICP-MS } \\
\text { Reference Section 4.1.2.4 for Details }\end{array}$} \\
\hline S11994-2 & 0.018 & 0.017 & 0.095 & N.A. & N.A. & 0.4 & N.A. & 11.1 & 4.4 & 11.0 & 7.8 \\
\hline \multicolumn{12}{|c|}{$\begin{array}{c}\text { Controlled Oxidation Plasma Melt With 5\% } \mathrm{O}_{2} \text { in Helium: ICP_MS } \\
\text { Reference Section 4.1.2.5 for Details }\end{array}$} \\
\hline S11994-3 & 0.018 & 0.016 & 0.092 & N.A. & N.A. & 0.4 & N.A. & 10.5 & 9.6 & 7.6 & 6.5 \\
\hline \multicolumn{12}{|c|}{$\begin{array}{c}\text { Controlled OxidationPlasma Melt With } 5 \% \text { and } 10 \% \mathrm{O}_{2} \text { in Helium (With a Refractory Lining): ICP-MS } \\
\text { Reference Section 4.1.2.6 for Details }\end{array}$} \\
\hline S11994-6 & 0.018 & 0.016 & 0.094 & N.A. & N.A: & 0.5 & N.A. & 12.5 & 10.7 & 7.8 & 4.8 \\
\hline S11994-5 & 2.9 & 2.8 & 3.2 & N.A. & N.A. & 0.3 & N.A. & 14.2 & 9.8 & 13.2 & 5.3 \\
\hline \multicolumn{12}{|c|}{$\begin{array}{c}\text { Commercial Scale Air Induction Melt Performed at AFFCO: X-Ray Fluorescence Spectroscopy } \\
\text { Reference Section 4.2.2 for Details }\end{array}$} \\
\hline S72294-3 & 0.34 & 0.26 & 0.21 & N.D. & N.A. & 9.7 & 0.36 & 2.58 & 0.13 & 4.78 & $\begin{array}{l}22 . \\
1\end{array}$ \\
\hline S72294-1 & 0.11 & 0.076 & 0.072 & N.D. & N.A. & 14.4 & 0.36 & 2.44 & 0.28 & 4.38 & $\begin{array}{l}25 . \\
8\end{array}$ \\
\hline
\end{tabular}




\begin{tabular}{|c|c|c|c|c|c|c|c|c|c|c|c|}
\hline \multirow{2}{*}{$\begin{array}{l}\text { SAMPLE } \\
\text { ANALYZED }\end{array}$} & \multicolumn{11}{|c|}{ ELEMENT } \\
\hline & $\begin{array}{c}\mathrm{Ce} \\
(\%)\end{array}$ & $\underset{(\%)}{\mathrm{La}}$ & $\begin{array}{l}\text { Nd } \\
(\%)\end{array}$ & $\begin{array}{c}\text { Cs } \\
(\mathbf{p p m})\end{array}$ & $\begin{array}{c}\mathrm{Sr} \\
(\%)\end{array}$ & $\begin{array}{c}\text { Al } \\
(\%)\end{array}$ & $\begin{array}{l}\mathrm{Ca} \\
(\%)\end{array}$ & $\begin{array}{c}\mathrm{Cr} \\
(\%)\end{array}$ & $\begin{array}{r}\mathrm{Fe} \\
(\boldsymbol{\%}) \\
\end{array}$ & $\begin{array}{l}\text { Mn } \\
(\%)\end{array}$ & $\begin{array}{c}\text { Si } \\
(\%)\end{array}$ \\
\hline S72294-2 & 0.084 & 0.058 & 0.039 & N.D. & N.A. & 15.4 & 0.40 & 2.28 & 0.12 & 4.16 & 24. \\
\hline \multicolumn{12}{|c|}{$\begin{array}{c}\text { Commercial Scale Air Induction Melt Performed at Newport News: ICP-MS } \\
\text { Reference Section 4.2.3 for Details }\end{array}$} \\
\hline S11994-4 & 0.019 & 0.016 & 0.093 & N.A. & N.A. & 0.7 & N.A. & 3.5 & 1.1 & 1.7 & 9.5 \\
\hline \multicolumn{12}{|c|}{$\begin{array}{l}(\%)=\text { Weight Percent } \\
\text { (ppm) = Parts Per Million } \\
\text { N.A. = Not analyzed } \\
\text { N.D. = Not detected }\end{array}$} \\
\hline
\end{tabular}




\section{RECOMMENDATIONS FOR FUTURE WORK}

1. Demonstrate the technology established on surrogates on full-scale VIM melts using selected radioactive scrap material.

2. Continue pilot scale induction melts to establish the kinetics of decarburization in VIM using gaseous and solid oxidizers.

3. Develop the use of cold hearth plasma melting for cutting, consolidation, and refining of surrogate-containing scrap material. This work will require optimization of torch design to allow polarity changes and use of oxidizing gases.

4. Conduct a basic study to investigate the influence of torch polarity on oxidation potential in cold hearth plasma melting. 


\section{DECONTAMINATION AND DECARBURIZATION OF STAINLESS STEEL AND CARBON STEEL BY MELT REFINING}

\section{SECTION SIX}

\section{REFERENCES}

Atteridge, D.G., Buckentin, J., J. Carter, Davis, H.L., Devletian, J.H., Scholl, M.R., Turpin, R.B., Webster, S.L., Mizia, R.E. (Ed.), "Refining Technology for the Recycling of Stainless Steel Radioactive Scrap Metals: FY 94 Bi-Annual Report," INEL-DOE, WINCO-1224, 97 p., 1994.

Bechtold, T.E. (Editor), "WINCO Metal Recycle Annual Report, FY 1993," INEL-DOE, WINCO-1172, 77 p., 1993.

Bechtold, T. E. (Editor), "INEL Metal Recycle, Annual Report" INEL-94/0067, September 1994.

Bergsman T.M., PNL Hanford, Washington, June 1991, Private Communication with R.E. McAtee, Hanford, WA, June, 1991, (as referenced in McAtee, 1991.)

Buckentin, J. M. R., "Melt Decontamination of Radioactive Stainless Steel by Electroslag Remelting", $\mathrm{PhD}$. Thesis in Materials Science at Oregon Graduate Institute of Science and Technology, 241 p., March 1996

Dyer, N.C., Bechtold, T.E. (Editor), "Radionuclides in United States Commercial Nuclear Power Reactors", WINCO-1191, INEL-DOE, 26 p., 1994.

Elert, M., Wiborgh, M., "Basis for Criteria for Exemption of Decommissioning Waste: Reprocessing of Dust from Recycling of Steel", Report for Swedish Radiation Protection Institute, Contract No. P672.92, 1992.

Elert, M., Wiborgh, M., Bengtson, A., "Basis for Criteria for Exemption of Decommissioning Waste", KEMAKTA AR 91-26, Kemakta Konsult AB, Stockholm, Sweden, 1992.

Elliot, J.F., McGleiser, Ramakrishnia, N., "Thermochemistry of Steelmaking, V II", Addison-Wesley, 1963.

Frost, R. H., "Refining Technologies for Radioactive Stainless Steel Scrap", Final Report Contract No. C86-110877-009, Colorado School of Mines, 61 p., 1996. 
Gerding, T.J., Seitz, M.G., Steindler, M.J., "Salvage of Plutonium-and AmericiumContaminated Metals," Argonne National Laboratory, Chemical Engineering Division, 00658812-79-9807-0191, 1979.

Herbst, C. A., Loewen, E. P., Nagel, C.J., and Protopapas, A., "Quantum-Catalytic Extraction Process Application to Mixed Waste Processing," Proceedings of the International Topical Meeting on Nuclear and Hazardous Waste Management, Spectrum '94, Atlanta, Ga, August 14-18, ANS.

Hooker, R.L., "Incinerator Carryover Tests with Dysprosium as a Stand-In for Plutonium," DPST-81-603, 1981.

Imrich, K.J., Leader, D.R. Iyer, N.C., Louthan, M.R., Recycle of Radiologically Contaminated Stainless Steels," Westinghouse Savannah River Company Internal Report, October, 1994

Janberg K.G., Rittscher D., "Comparison of Decontamination and Melting with Direct Disposal," Decommissioning of Nuclear Installations-1990, GNS Gesellschaft fur NuklearService, Germany, 1990.

Levitz N., Gerding T.J., Winsch I.O., Cannon T.F., Steindler M.J., "Volume Reduction and Salvage Considerations for Plutonium-Contaminated Ferrous Metal," CONF-750902-9, Argonne National Lab; AICHE Symposium Series, Vol. 72, No. 154, Jan. 1, 1975.

Lupis, C. H. P., "Chemical Thermodynamics of Materials," ISBN 0-444-00779-2, Elsevier Scienc Publishing Co., Inc, 1983.

McAtee R.E., Beal M., "Comparison of the High Temperature Chemistry of Plutonium and Rare Earths, a Review Study," EGG-WTD-9801, Idaho National Engineering Laboratory, Sept., 1991.

Mizia R.E., Idaho National Engineering Laboratory, Montana Tech, Butte Montana, Private Communication with A. Liby, Manufacturing Sciences Corporation, June, 1993.

Nichols, F., "Manufacturing Sciences Corporation-Past, Present, and Near Future," Marketing brochure, December, 1994.

Nichols, F., "Feasibility Analysis of a Western U. S. Radioactive Scrap Steel Mill," Document D2-95-C265-F, Manufacturing Sciences Corporation, MSE/WETO Contract No.95-C265-F, September, 1995 
Ochiai A., Yamamoto T., "Method of Volume-Decreasing and Decontaminating Radioactive Metal," Japanese Patent No. JP 57-132522, Japan, July, 1982.

Paolini, D.J., "Decontamination of Metals by Melt Refining/Slagging", MSc. Thesis in Metallurgical Engineering at Montana Tech of the University of Montana, 128 p., May 1995.

Raraz, Mishra B., Averill W.A., "Rocky Flats Plant Report", DOE Report Holdings, RFP$4628,1993$.

Reimann G.A., "Technical Assessment of Processes to Enable Recycling of Low-Level Contaminated Metal Waste," EGG-MS-9879, Idaho National Engineering Laboratory, Oct., 1991.

Richardson F.D., Physical Chemistry of Melts in Metallurgy, Vol.I, Academic Press Inc., New York, New York 10003, 1974.

Schuster E., Haas E.W., "Behavior of Difficult to Measure Radionuclides in the Melting of Steel," EUR-12690, Belgium, Decommissioning of Nuclear Installations, Elsevier Applied Science, 1990, or Advances in Ceramics Vol. 20: Nuclear Waste Management II, 1990.

Shaw P.G., EG\&G Idaho Inc., Idaho Falls, Idaho, Private Communication with R.E. McActee 1988, Referenced in EG\&G report, EGG-WTD-9801, Authored by R.E. McAtee and M. Beal (1991), Jan., 1988.

Shaw P.G., Loomis G.G., "Plutonium Contamination Control Studies During A Glove- Box Scale Simulated Evacuation of TRU Buried.Waste,"EGG-WM-8289, Oct., 1988.

Stockdale J.A.D., Bostick, W.D., Hoffmann, D.P., Lee, H.T., "Surrogate Formulations for Treatment of Low-Level Mixed Waste: Part 1: Radiological Surrogates," DOE Contract ACO5-840T21400; AC05-760R00033. Order Number DE94011598, Source: OSTI; NTIS; INIS; GPO Dep.

Stoots P.R., "In Situ Vitrification Intermediate-Scale Sampling and Analysis Plan," EGG-WM-8661, 1990.

Turnbull A.G., Wadsley M.W., CISRO-MONASH Thermochemistry System, Monash University, Department of Chemical Engineering, Clayton, Victoria 3168, Australia, 1992.

Weidner J.R., EG\&G Idaho, Inc. Idaho Falls, Idaho, Private Communication with R.E. McAtee June 1997, Referenced in EG\&G report EGG-WTD-9801, Idaho Falls, June, 1991. 
Weldon, T.A., "Decontamination of Metals by Melt Refining/Slagging", MSc. Thesis in Metallurgical Engineering at Montana Tech of the University of Montana, 131 p., June 1994.

Whitworth C.G., MSE, Butte, MT, Private communication with L.G. Twidwell, Montana Tech, Butte, MT, 1993.

Whitworth C.G., Twidwell L.G., Jenkins T.W., Wyss G.F., "Slag Chemistry and Metals Volatilization in the Plasma Arc Furnace Experiment," Department of Energy, Spectrum'92, 1992.

Worcester, S.A., Twidwell, L.G., Paolini, D.J., Weldon, T.A., Mizia, R.E. (Ed.), "Decontamination of Metals by Melt Refining/Slagging-An Annotated Bibliography", WINCO-1138, INEL-DOE, 89 p., 1993.

Worcester, S.A., Twidwell, L.G., Paolini, D.J., Weldon, T.A., Mizia, R.E. (Ed.), "Decontamination of Metals by Melt Refining/Slagging: First Year Progress Report", WINCO-1198, INEL-DOE, 47 p., 1994.

Worcester, S.A., Twidwell, L.G., Paolini, D.J., Weldon, T.A., Mizia, R.E. (Ed.), "Decontamination of Metals by Melt Refining/Slagging", Second International Conference on Materials Engineering for Resources, ICMR'94 AKITA, October 12-14,1994, Society of Mat'ls Engr for Resources of Japan and Res. Inst. of Nat. Resources, pp 62-75, 1994.

Worcester, S.A., Twidwell, L.G., Paolini, D.J., Weldon, T.A., Mizia, R.E. (Ed.), "Decontamination of Metals by Melt Refining/Slagging", Proc. Vacuum Metallurgy Conf. on Liquid Metal Processing and Casting, Sante Fe, N.M., Sept. 11-14, 1994, 14 p., 1994.

Worcester, S.A., Twidwell, L.G., Paolini, D.J., Weldon, T.A., Mizia, R.E. (Ed.), "Decontamination of Metals by Melt Refining/Slagging: An Annotated Bibliography Update on Stainless Steel and Steel," DOE De-AC07-94ID13223, INEL-95/0123, 1995. 